\author{
by \\ Mark Dhia Justin Antoine, BA, York University, 2009 \\ A Major Research Paper \\ presented to Ryerson University \\ in partial fulfillment of the requirements for the degree of \\ Master of Planning \\ in \\ Urban Development
}

Toronto, Ontario, Canada, 2011

PROPERTY OF -

RYEROON LAWERSTTY LRRAAY

(C) Mark Dhia Justin Antoine 2011 
I hereby declare that I am the sole author of this major research paper.

I authorize Ryerson University to lend this paper to other institutions or individuals for the purpose of schołarly research.

I further authorize Ryerson University to reproduce this paper by photocopying or by other means, in total or in part, at the request of other institutions or individuals for the purpose of scholarly research. 


\title{
MARKHAM'S NEW URBANIST PARADIGM: NEOLIBERALISM, GENTRIFICATION AND COMPETITIVE GOVERNANCE
}

\author{
(C) Mark Dhia Justin Antoine, 2011 \\ Master of Planning \\ in \\ Urban Development \\ Ryerson University
}

\begin{abstract}
The rise of competitive governance through the ideology of neoliberalism has led to contemporary development projects that rely on capital accumulation to economically prosper. Given that a majority of current literature pertaining to competitive governance is fundamentally urban, this paper argues that this phenomenon is also occurring in suburban areas. Utilizing the Langstaff Gateway in the Town of Markham, Ontario as a case study, this paper outlines the ramifications of competitive governance as it relates to new urbanism and the recently coined term of new-build gentrification. An argument is made that the Langstaff Gateway represents the most contemporary new-urbanist development paradigm within the Greater Golden Horseshoe. Two major components frame this paper: the first elaborates upon neoliberalism through a critical geographical perspective, while the second provides pragmatic planning evidence of this phenomenon "on the ground" through the Langstaff Gateway. Findings suggest that, although inherently entrenched within municipal and metropolitan neoliberal governance frameworks, the Langstaff Gateway represents a progressively-planned paradigm toward suburban intensification in the Greater Golden Horseshoe.
\end{abstract}

KEY WORDS: competitive governance; Langstaff Gateway; Markham; neoliberalism; newbuild gentrification; new urbanism 


\section{Acknowledgements}

In the production of this research paper, I am first very grateful to my supervisor, Ron Keeble, for his passionate and insightful guidance, detailed comments and discussion, and continuous encouragement in the many stages and forms of research and writing.

I am also grateful to Beth Moore Milroy for her helpful advice and initial words of inspiration to pursue this research. I also thank my second reader, David Amborski, for providing me with comments during the later stages of this research, and my colleague Christopher Correia, for our often profound conversations about the suburbs.

Finally, a large amount of gratitude goes to my parents, Gail and Tony, for their unwavering and continued support throughout the entire research process. 


\section{Dedication}

For Laura, whose optimism and enduring smile provided inspiration beyond words during the writing of this paper. 
Chapter 1: Introduction

\section{Table of Contents}

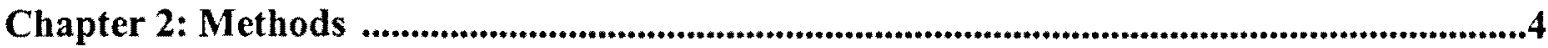

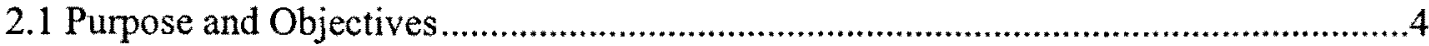

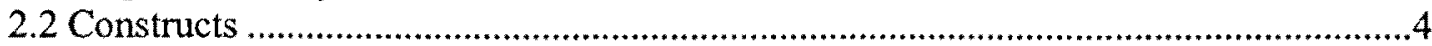

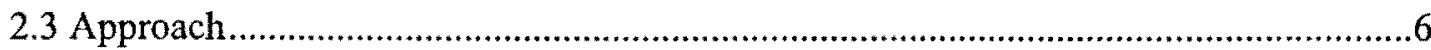

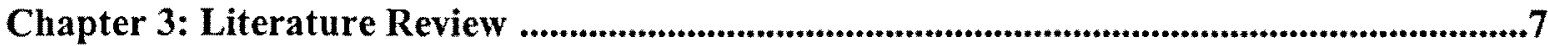

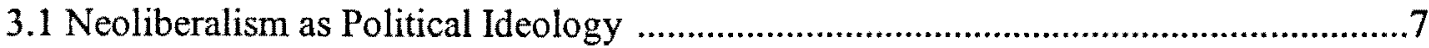

3.2 Neoliberalism as Local Political-Geography ...............................................................11

3.3 Governance: From Urban Entrepreneurialism to Global Competitiveness .................13

3.4 Neoliberalism as Demonstration Project ....................................................................20

3.5 But What about the Suburbs? The Rise of Neoliberal Suburban Governance ............24

3.6 Gentrification: From Marginal Oddity to Systematic Strategy ....................................28

3.7 New Urbanism: Context and Criticisms ………..........................................................35

Chapter 4: Background and Context ..........................................................................................42

4.3 Markham's New Urbanist Demonstration Projects ...................................................42

4.4 Planning the Greater Golden Horseshoe ..................................................................49

Chapter 5: Markham's Latest New Urbanist Demonstration Project - The Langstaff

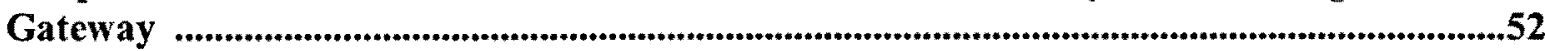

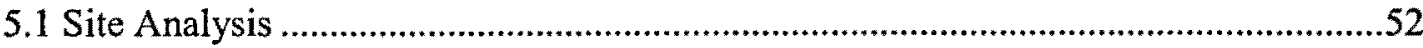

5.2 History and Background .........................................................................................58

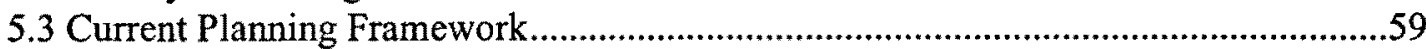

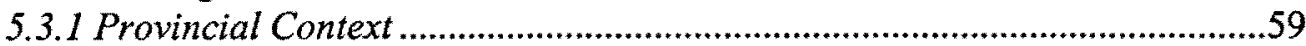

5.3.2 Regional Context ............................................................................................62

5.3.3 Municipal Context .......................................................................................62

5.3.3.1 Design and Land Use Framework - The Langstaff Gateway Land Use and Built Form Master Plan ....................................................64

5.3.3.2 Municipal Policy Framework - The Langstaff Gateway Secondary

Plan

Chapter 6: Analysis and Recommendations …….................................................................71

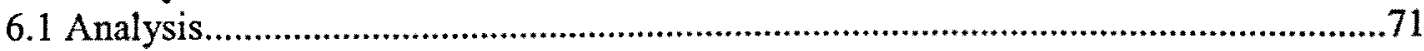

6.1.1 Competitive Governance........................................................................71

6.1.2 Contemporary New Urbanism ................................................................73

6.1.3 New-Build Gentrification .........................................................................75

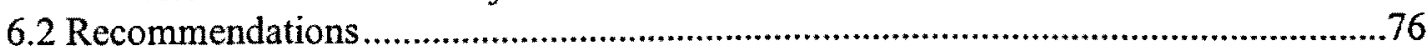

Chapter 7: Conclusion - Lessons Learned from the Langstaff Gateway................................84

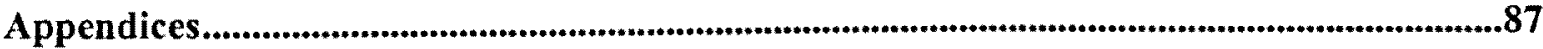

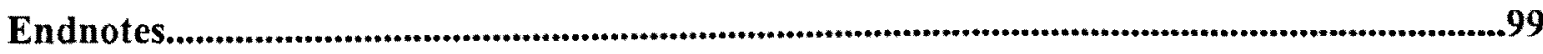

References..........................................................................................................................101 


\section{List of Tables and Figures}

\section{Tables}

1. The Shift from Traditional Government to Competitive Governance......................................16

2. Growth Plan For the Greater Golden Horseshoe, Policy Backgrounder ..............................51

\section{Figures}

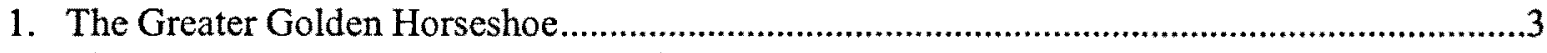

2. The Forces, Agents, and Outcomes of Urban Competitiveness ...........................................21

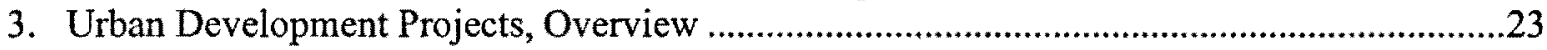

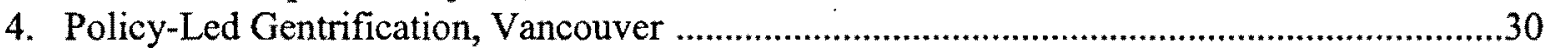

5. Selective New Urbanism............................................................................................4

6. New Urbanist-inspired Secondary Plans, Town of Markham, 1994-1997 ............................44

7. Lane-based Housing, Comell Neighbourhood .................................................................46

8. New Urbanist versus Conventional Neighbourhoods, Markham ........................................48

9. The Langstaff Gateway and Surrounding Context ...........................................................53

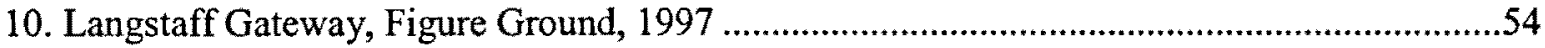

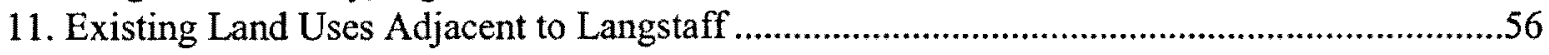

12. Proposed Yonge Subway Extension ..............................................................................61

13. Langstaff Gateway Land Use, Massing, and Proposed Housing Types ................................70 


\section{List of Appendices}

APPENDIX A: General Documents.

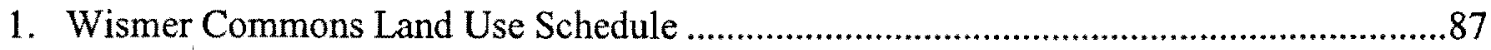

APPENDIX B: List of Provincial and Regional Documents.....................................................8

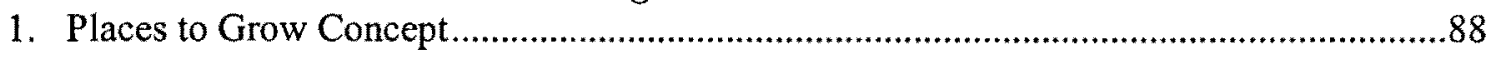

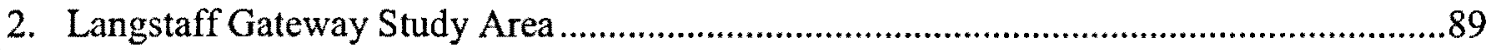

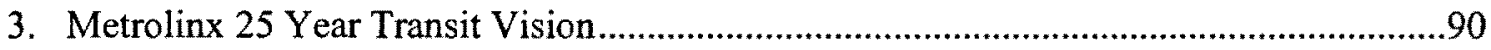

4. The Region of York Urban Structure Schedule, 2010 ........................................................91

APPENDIX C: List of Langstaff Gateway Documents ........................................................92

1. Land Use Concept, Langstaff Development Feasibility Study, 1997 …….........................92

2. 1,000 Metre Radius Surrounding the Langstaff Gateway ….............................................93

3. Langstaff Gateway Master Plan, Phasing and Implementation Strategy ............................94

4. Langstaff Gateway Secondary Plan, Proposed Land Use...................................................95

5. Langstaff Gateway Secondary Plan, Transit Plan..............................................................96

6. Langstaff Gateway Secondary Plan, Height Control Plan.................................................97

7. Langstaff Gateway Secondary Plan, Development Blocks and FSI...................................98 


\section{Chapter 1: Introduction}

The often stated notion that "planning is politics" has never been more relevant. New planning ideologies such as new urbanism and Smart Growth have become the panacea to attain the necessary attributes of a compact and sustainable city, particularly in suburban municipalities across North America and beyond (Grant, 2002; 2005; 2009; Moore, 2010). Parallel to this ideology is the manifestation of neoliberal governance structures over the last thirty years, as governments compete with each other to acquire capital in an increasingly competitive global market. Such governments have employed the use of "demonstration projects" as a tool to stay afloat on the world stage (Harvey, 1989a; Moore, 2010; Swyngedouw, Moulaert, \& Rodriguez, 2002), which are consistently reimagined to suit market forces, and present new challenges to urban planning practice. In its most contemporary manifestation, new urbanism's basic concepts, design fundamentals, and planning principles are cherry picked to suit the market and political needs of developers and bureaucrats, respectively. This has led to concerns of not only the physical environment, as new urbanist projects consistently materialize into endless sprawl typical to post-war North America suburbia, but also largely the social environment, as the systematic use of gentrification inter alia is increasingly used to revive the often maligned North American post-war suburb.

Given these impeding and always-in-flux factors, the purpose of this paper is to understand and critically analyze the most recent form of new urbanist demonstration project within the Greater Golden Horseshoe (GGH; see Fig.1). Given current provincial land use planning legislation, which champions intensification, mandated population targets, and nodalstyle development, suburban municipalities within the GGH have been given the task to find contemporary ways at intensifying their current built-up area. The Langstaff Gateway is one 
such development which rises to the task. Located in the Town of Markham - a suburban municipality known for being the "poster child" of new urbanism - the Langstaff Gateway represents a new paradigm in suburban development for the GGH. The social, physical, and politico-economic ramifications, however, are widespread. Although the master-planned community is objectively new urbanist in nature, it is reliant upon a myriad of factors to become physically and economically sustainable. Furthermore, the planning and design of the Langstaff Gateway is largely at risk of reflecting the processes of "new-build gentrification" (Davidson and Lees, 2005), the most contemporary form of systematic "policy-led" gentrification. Therefore, an argument is made that the planning, design, and development of the Langstaff Gateway is representative of a competitive governance structure entrenched in neoliberal ideology.

Given these arguments, this paper consists of two major components. The first component analyzes the ideological context of neoliberal governance, new-build gentrification, and new urbanism; while the concepts of neoliberal governance and new-build gentrification have been studied primarily under urban conditions (see Brenner \& Theodore, 2002 and Davidson and Lees, 2005, respectively) this paper argues that such forces are also occurring within suburban areas as well. The historical context and recent criticisms of the new urbanist ideology is then outlined with a cognizance towards the above mentioned forces. The second component pragmatically and critically examines the processes behind the development and planning of the Langstaff Gateway as it relates to current planning policy and ideology. A , historical account and site analysis of the Langstaff Gateway is followed by a discourse analysis of the site's Master Plan (2009) and Secondary Plan (2010); two planning documents that are largely shaped by reformed new urbanist principles and competitive governance structures. Finally, this paper provides planning recommendations for the development of the Langstaff 
Gateway and future planning policy within the GGH. An argument is made that if new urbanism and competitive governance are the new catalysts for planning and development in the GGH, urban planners must champion the necessary financial and regulatory tools available to them in order to regulate market and social inefficiencies present within this new paradigm.

\section{Figure \#1: The Greater Golden Horseshoe}

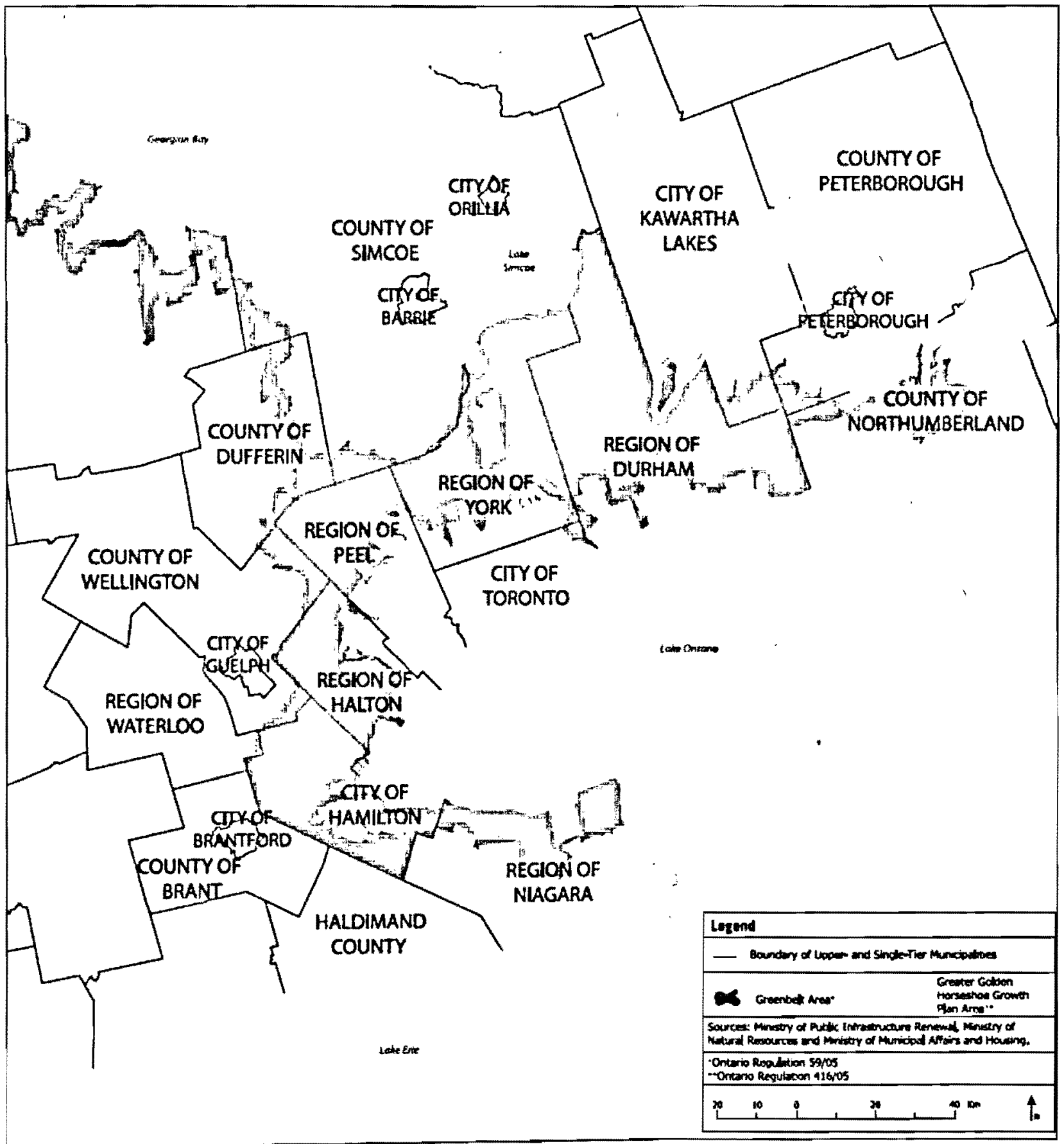




\section{Chapter 2: Methods}

\subsection{Purpose and Objectives}

The purpose of this research is to outline and critically analyze a new suburban planning paradigm through an analysis of the Langstaff Gateway in Markham. Embracing the principles of new urbanism since the development of Cornell in 1996, the Town of Markham has advocated itself as a "centre of excellence for new urbanism", aggressively attempting to implement mixed-use and compact-friendly designs into planned neighbourhoods following the apparent success of Cornell. The Langstaff Gateway - while ultimately new urbanist in principle - represents a precedent in suburban planning practice. Unparalleled densities, physical site restrictions, reformed provincial planning policy, and the proposed allocation of transit infrastructure are the major forces that will shape the Langstaff Gateway. This paper, however, also outlines the political-economic lens behind the Langstaff Gateway development. An argument is made that the processes behind the development is characteristic of a competitive governance system rooted in neoliberal ideology, perpetuating the utilization of systematic "new build" gentrification - the mass produced "blueprint" for development linked to global urban strategies and neoliberal policy (Davidson \& Lees, 2005; see also Smith, 2002). Therefore, the following objectives for this paper are:

- To explore the phenomenon of neoliberalism, particularly in relation to local governance structures and urban planning practice;

- To outline - through the Langstaff Gateway - how new urbanism and "new-build gentrification" relates to neoliberal ideology; and

- To explore, critically analyze, and provide planning recommendations toward the Langstaff Gateway development with a cognizance of the above political forces at work

\subsection{Constructs}

Given the breadth and complexity of concepts such as neoliberalism and gentrification, it 
is imperative to outline what these words mean in regard to this research paper. Neoliberalism is represented here at its most local level. Contemporary research regarding neoliberalism (Brenner \& Theodore, 2002; Larner, 2000; Peck \& Tickell, 2002) has begun to unpack its macroeconomic ideology and apply it to (sub)urban areas. Findings suggest that the outputs of neoliberalism at the local scale are ephemeral and always in flux, largely due to neoliberalism (as an ideology) being a path-dependent, evolutionary trajectory in order to address market vulnerabilities and government failures (Peck \& Tickell, 2002). Thus, a disjuncture exists between macroeconomic neoliberal policy and its local, "actually existing" outputs (Brenner \& Theodore, 2002). It would seem myopic, however, to understand this concept as strictly a market-based dynamism, as local government (and the larger forces of "governance") plays a key role in satisfying capital accumulation through various outputs. Local governments have transformed into facilitators (rather than regulators) of such accumulation, largely due to the rhetoric of neoliberalism and globalization; this transformation has characterized local governments as one of many actors within the framework of competitive governance. Therefore, it is argued here that the processes of development for the Langstaff Gateway represent a competitive governance structure at work.

Similarly, gentrification is a term used to explain many occurrences of social displacement due to changing physical form. It is described here, however,'as a systematic strategy tied to the constructs of neoliberalism that is policy-led (i.e by governments) and implemented by market actors (e.g. development consortiums). This contemporary appearance of gentrification has been labeled "new-build" gentrification by Davidson and Lees (2005). The author's initial research into new-build gentrification has primarily occurred in the United Kingdom, particularly London's Riverside. However, given a growing body of literature 
(Boddy, 2007; Davidson, 2007; Niedt, 2006), the concept has become highly contested: many argue if it reflects the traditional definition of gentrification at all. The purpose of employing this term here is to provide evidence that new-build gentrification can (or as a minimum has the potential to) occur in a suburban, North American context.

Thus, the intent of this paper is to engage with the above-mentioned constructs as it relates to the planning ideology of new urbanism. The case study under review is highly reflective of the above constructs, yet it is not outlined here to simply provide concrete evidence that such phenomena is occurring. Indeed, it is imperative to argue that the Langstaff Gateway is certainly ripe with the forces of competitive governance and the ramifications of new-build gentrification. However, this report also seeks to provide pragmatic answers to such problems through the tools of urban planning; if these forces do exist, how do planners and the planning profession at large deal with such issues "on the ground"? Subsequently, if the Langstaff Gateway indeed represents a new paradigm in suburban development, will it work in other areas of the GGH? - And if not, why? This paper attempts to tackle such questions during its concluding chapters.

\subsection{Approach}

Qualitative methods were primarily employed for this paper. Research involved a strict discourse analysis of the Langstaff Gateway Secondary Plan (2010), the Langstaff Land Use and Built Form Master Plan (2009), and the Langstaff Development Feasibility and Urban Design Study (1995). Furthermore, multiple visits to the site provided sound research in regard to the areas physical constraints and opportunities. Finally, informal visits to the Town of Markham Planning Department provided appropriate quantitative data and historical information. 


\section{Chapter 3: Literature Review}

\subsection{Neoliberalism as Political Ideology}

Neoliberalism - a theory once considered merely a utopian movement manufactured in Chicago in the 1970s through the abstract intellectualism of Friedrich Hayek (1944) and Milton Freidman (1962) - has become the dominant economic practice and ideological rationalization for globalization and state reform in the $21^{\text {st }}$ century (Peck \& Tickell, 2002). Galvanized from the writing of eighteenth-century liberalists Adam Smith and John Locke, the crux of neoliberal ideology is the assumption that individual freedoms are guaranteed by freedom of the market, which occur predominantly through free trade, privatization, deregulation, and withdrawal from the state in many areas of social provision. Human well-being, therefore, is best advanced by liberating individual entrepreneurial freedoms through an institutional framework that champions the above provisions, as the role of the state becomes an apparatus to create and preserve this framework (Harvey, 1989a; 2005). This ideology of open, competitive, and unregulated markets was seen as the optimal mechanism for (globalized) economic development, as the post-WWII economic order - largely influenced by Keynesian economics such as welfare state provisions, monetary regulation, and market controls - began to suffer a major recession in the $1970 \mathrm{~s}$ (Brenner \& Theodore, 2002).

Neoliberal theory materialized as an aggressive political movement, first under the dictatorship of Augusto Pinochet in Chile (1973), followed by its exacerbation under the governments of Margaret Thatcher in Britain (1978) and Ronald Reagan in the United States (1981), until taking a more technocratic form through the "Washington Consensus" (1990)' (Boudreau, Keil, \& Young, 2009; Harvey, 2005; Peck \& Tickell, 2002). Although the rubrics of Thatcherism and Reaganism in the 1980 s represent the most aggressive neoliberal regimes, 
social-democratic nations including New Zealand, Germany, the Netherlands, France, Italy, Sweden, and Canada mobilized and followed this political suit, albeit at a temperate level. The outward institutionalization of neoliberalism to market forces outside the developed world was further perpetuated by transnational agents such as the General Agreement on Tariffs and Trade (GATT), the World Trade Organization (WTO), and the International Monetary Fund (IMF) This further permitted the free movement of global capital across space beginning in the 1980s (Brenner \& Theodore, 2002; Harvey, 2005; Sassen, 1996); as Brenner and Theodore (2002) state, "neoliberalism had become the dominant political and ideological form of capital globalization" (p.350).

Many scholars have referred to three transformations or "global periodizations" of neoliberal policy, primarily through varied institutional landscapes and power configurations (Brenner \& Theodore, 2002; see also Boudreau, Keil, \& Young, 2009; Craig \& Porter, 2006; Harvey, 2005; Keil, 2002; Larner, 2000; Peck and Tickell, 2002; Ruckert, 2006). "Roll-back neoliberalism" commonly refers to the materialization of neoliberalism as an ideological abstraction in the early 1970s, into an active process of deregulation and destruction of Keynesian-welfarist and social institutions in the 1980s. This was followed by "roll-out neoliberalism" in the 1990s, where market-guided regulation attempted to create economic growth while simultaneously mending the sociopolitical contradictions induced by earlier forms of neoliberal policy (Brenner \& Theodore, 2002; Peck and Tickell, 2002). Finally, the term "inclusive" or "push back" neoliberalism was introduced in the 2000 s as a means to delineate a "Post-Washington Consensus" era (Peck \& Tickell, 2002; Ruckert, 2006). Here, neoliberalism witnessed a deviation from its previous forms of its "roll back" and "roll out" guise, primarily due to an influx of developing countries mandated to produce Poverty Reduction Strategy Papers 
before they could be considered for debt relief by the World Bank. Inclusive/push back neoliberalism has recently established a hybrid nature of governance structures, where "traditional" forms of governments (i.e. those that are concerned with social welfare and service production) have been reintroduced into the neoliberal framework, coalescing with the traditional market-reliant forces of neoliberalism (McGuirk, 2005; see also Ruming, 2005; Cook \& Ruming, 2008). Some have argued that this policy framework merely reinforces the neoliberal agenda by "foreclosing social and political alternatives to neoliberal practice" (Ruckert, 2006, p.36; see also Soederberg, 2005; Weber, 2004), or that they simply perpetuate the policies of the Washington Consensus while providing a direct response to any threat of neoliberal policy (Soederberg, 2005).

Neoliberal restructuring of welfare state processes is often associated with discourses of globalization largely due to the rhetoric of globalization and neoliberalism paralleling as exogenous, natural forces with immense causal efficacy (Lamer, 2000; Peck \& Tickell, 2002). The perpetuation of neoliberalism as a political ideology is largely due to its self-evident alignment with globalized political-economic powers, leading to what Bourdieu (1998) calls a "strong discourse... because it has all the powers of a world of power relations which it helps to make as it is" (p.95). Yet because the all-encompassing term "neoliberalism" is regarded as an immense hegemonic position in global agencies and discourses, there is a perceived vagueness when attributed as an end goal or object. As Brenner and Theodore (2002) argue, the disjuncture between ideology and practice of neoliberalism through various world-wide manifestations (e.g. Thatcher's Britain compared to Reagan's America) suggests that the phenomenon is less coherently bounded by an "ism" (or end state) and more as a process: a term labeled neoliberalization by Peck and Tickell (2002). Thus, one of the most fundamental features of 
neoliberalism is that it exists in numerous configurations, where neoliberalized projects and programs reveal a complex and hybrid political imaginary rather than a unified or coherent philosophy, ideological form, regulatory framework, or actualized policy regime (Brenner \& Theodore, 2002, Larner, 2000).

Thus, neoliberalism works upon a "path-dependent evolutionary trajectory" (Brenner \& Theodore, 2002, p.362), where policies are routinely modified qualitatively in order to address governance failures, crises tendencies, vulnerabilities, and contradictions. The process of neoliberalization, therefore, is place-specific and poitico-ideological by nature. It is neither uniform nor universal in effect, and is present in many guises. It is articulated through various scales (global, national, regional, and local) and has been constantly changing through historical trajectory since its inception in the 1970s (Keil, 2002). But how has neoliberal policy affected urban and suburban development, both physically and socially? What is the connection between (sub)urbanization and neoliberalization? And - perhaps most importantly - how do the macroeconomic and path-dependent forces of globalized neoliberalism percolate to local government planning policy - or as Larner (2000) states in regard to Foucault - neoliberalism as "governmentality" (p.12)? Until now, this brief historical context of neoliberalism focused on the necessarily inexplicit global development theories through a political economic and neoGramscian lens. Yet what is particularly important in regard to this paper is how the global forces of neoliberalism have: transformed local governance structures; assisted in the creation of new forms of local patterns of (sub)urban development; and perpetuated ramifications in regard to development such as gentrification, place-marketing, public-private partnerships, and social control mechanisms. Fundamentally, how does the polycentric and multiscalar character of neoliberalism, through its geopolitical and geo-economic projects, affect the process of urban 
restructuring and redevelopment? The following sections will outline how the macroeconomic processes of neoliberalism have affected local space and government frameworks in regard to urban and suburban development.

\subsection{Neoliberalism as Local Political-Geography}

The macroeconomic, ceteris paribus nature of neoliberalism outlined above systematically misrepresents place-based institutional frameworks and policy environments. Neoliberal ideology exists under the presumption that the market operates in the same way regardless of geographic location or contextually specific institutional landscapes. Yet, the notions of space and scale have become increasingly important within neoliberal literature, particularly within the lenses of geography and social science. As notable political geographers such as David Harvey $(1982 ; 1989 a ; 1989 b ; 2005)$ and Neil Smith $(1984 ; 1987 ; 1996 ; 2002)$ continually explore issues related to space, capitalism, governance, and gentrification, an influx of academic interest has flourished beginning in the mid-1990s and early $2000 \mathrm{~s}$ in regard to neoliberal geo-economics and governance at the local (i.e. urban or regional) scale (Boudreau, Keil, \& Young, 2009; Cook \& Ruming, 2008; Keil, 2002; Larner, 2000; Peck \& Tickell, 1994; 2002; Swyngedouw, 1992; Weber, 2002).

In order to realize the ramifications of this totalizing ideology, one niust look at the "on the ground" neoliberal projects which Larner (2000) calls "messy actualities" (p.14). Giving rise to Peck and Tickell's (2002) notion of neoliberalization, Brenner and Theodore's (2002) theory of "actually existing neoliberalism" conceptualize Lamer's statement of the disjuncture between macroeconomic neoliberal economics and its effects on cities and metropolitan areas through the mechanism of "neoliberal localization". Actually existing neoliberalism reflects the contextual 
embeddedness of neoliberal ideology - the restructuring and materialization of the mostly immutable and conformist laws of neoliberal practice into national, regional, and local scales. It reveals the transformation of traditional (national) scales of Fordist-Keynesian production into an increasingly "glocal" scale, where the global and local have become the justifiable levels toward the accumulation, regulation, and social polarization of capital. It is here where the confluence of neoliberal ideology, policy, and practice at regional and local levels coalesce through the process of "creative destruction" (Harvey, 1982). The geographical landscape is thoroughly transformed by an influx of capital accumulation in the form of development and redevelopment schemes which act as catalysts for areas of market-oriented growth.

Examples of creative destruction through local neoliberalization include the devolution of responsibilities to local municipalities, the creation of revenue collection districts and increased reliance upon local sources of revenue, an increase in public-private partnerships, and the privatization of municipal services (e.g. garbage collection). This has manifested into the creation of gated communities, urban enclaves, "purified" spaces of social reproduction, and the adoption of "highest and best use" policies in regard to land use planning (for an exhaustive list, see Brenner \& Theodore, 2002, p.369-372)

Given these examples, the forces of urban restructuring through creative destruction constantly "revalorize" (restore or increase value) and "devalorize" (devalue) space (Smith, $1984 ; 1996)$. However, it would seem myopic to view such creative destruction and accumulation as strictly market determined, as local governance structures continually regulate the uneven development of space. Weber (2002) outlines the regulatory dilemmas of local governance structures, which, as the author argues, must create the conditions for (profitable) capital accumulation while managing the political repercussions of such actions. Contemporary 
institutional mechanics of spatial planning and regulation initiatives within the neoliberal paradigm reflect the control of regional, metropolitan, and local space, combined with marketled, locally focused, and non-spatial policies and programs (McGuirk, 2005). This doublepronged approach perpetuates the creative destruction of urban built form and institutes a structure of governance which focuses extensively on performance, efficiency, and marketability in regard to land regulation.

This has produced what Cook and Ruming (2008) call a "reorientation of planning capacities away from spatial equity towards entrepreneurial and competitive paradigms" (p.212), which potentially exacerbate pressure on housing prices and land supply. Fundamentally, market centralization through globalized capital accumulation reflects such a paradigm, where governance structures are redirected as distributional entities into supply-side interventionists through regulatory frameworks which attract globalized capital (Cook \& Ruming, 2008). As Ruming (2005) proclaims, the contextualization of Brenner and Theodore's "actually existing neoliberalism" reflects "a mutually conducive process of market and state construction, where neither is hermetically sealed and where recognition of the state as the primary institution in the construction of market operations is vital" (p.83). Indeed, these political processes form a pivotal backdrop to the case study under review here.

\subsection{Governance: From Urban Entrepreneurialism to Global Competitiveness}

The emergence of neoliberal and global forces has led to the restructuring of urban space in North America, largely through changing governance structures and policies. Due to the varying extent in which policies and programs exist within local governance structures, it is indeed difficult to generalize the shifting ideologies of such structures throughout the last four 
decades. However, a consensus can be made that there has been a shift in governance ideology with the rise of globalization and neoliberal policy. Harvey's (1989a) seminal Marxist approach to this phenomenon outlines the reorientation of urban governance from a managerial perspective during the 1960s to an entrepreneurial one beginning in the mid-1970s. This transformation began, perhaps expectedly, during government reforms in Britain at approximately the same time neoliberal ideology coalesced as a policy framework. Other perpetuating factors for this initial shift include the recession of 1973, increased deindustrialization within developed countries, and fiscal austerity at the national and local levels. The characteristics of urban entrepreneurism are reflective of neoliberalization: increased centralization of planning powers; increased privatization of government operations; the assumption of risk by the public sector; and tokenistic community consultation and reduced public accountability (Owen, 2002). Although divergent academic opinions exist on whether urban entrepreneurialism is merely exaggerated (Hall \& Hubbard, 1996) or simply gained in importance and prominence due to globalizing factors (Murphy \& Wu, 1999; see also Owen, 2002), there is evidence that a growing trend of local governments are transforming into regulatory players who act as catalysts in facilitating (as opposed to stabilizing) market conditions for capital accumulation (Harvey, 1989a; MacLeod, 2002; Weber, 2002).

It is important here, however, to delineate the difference between "governance" and "government" when explaining the transition from managerial to entrepreneurial models. As Harvey (1989s) suggests, "the power to organize space derives from a whole complex of forces mobilized by diverse social agents" (p.6); governance reflects that of "coalition politics" where governments lend credence to civic boosterism in conjunction with local chambers of commerce, social sector agents, financial institutions, industrialists, and property developers. Therefore, 
contemporary political arenas represent a new epoch that sit in stark contrast to the Fordistmanagerial regime of social steering by elected government (MacLeod, 2002). This is first through the above-stated entrepreneurial model in the 1970s, and more recently into the multifaceted competitive model during the 1990s (Kipfer \& Keil, 2002).

Due to complexities amongst the autonomous actors stated above, the traditional structure of government has led to market failures in the provision of distributive and redistributive services. This has led to collective decision-making through governance as opposed to traditional "government". Government focuses on who governs and who has the power to act, while governance reflects the ability to coordinate various stakeholders' activities to make and implement decisions (see Table 1). Thus, the governance regimes of urban entrepreneurialism and competitiveness maintain marketable strategies through collective decision making, that influence the direction of globalized capital flow toward (sub)urban areas. This is through effective economic performance that combines the top-down strategic vision of development with bottom-up (i.e. market-driven) performance-oriented actions (Chatterjee and Lakshmanan, 2009).

The structures of entrepreneurial governance materialize into programs, policies, and projects that rely heavily upon the economic, social, political, and cultural contexts of the locality. In terms of development precedents, this can materialize into: the attraction of "hallmark" world events (e.g. the Olympics) (Owen, 2002); competition for primacy within the "world-urban-hierarchy" (Friedmann, 1986; Sassen, 2002); state "rescaling" and recalibration of policy regulation in an attempt to market the city as an international hub/global city (Brenner, 1998; 2009; Smith, 2002); and the creation of postmodern "spectacular development initiatives" which perpetuate systematic gentrification and socioeconomic polarization (Swyngedouw, 
Moulaert \& Rodriguez, 2002; Harvey, 1989a; 1989b; 1997).

Table \#1: The Shift from Traditional Government to Competitive Governance

\begin{tabular}{|l|l|}
\hline \multicolumn{1}{|c|}{ Traditional Government } & \multicolumn{1}{c|}{ Governance Under } \\
\hline 1. Coordination of economic activities & Entrepreneurialism/Competitiveness \\
2. Inter-sectoral relationships & 2. Market-hierarchy \\
3. Public vs. Private & 3. Public, private, and social actors \\
4. Transactional efficiency - processing & 4. Transformational efficiency - \\
information and adapting to external & continuous process of renewal and \\
signs such as prices and political & innovation, creating new resources and \\
pressures. & mobilizing under-utilized urban \\
5. Programs/agencies & resources. \\
& 5. Governance tools \\
\hline
\end{tabular}

Source: Chatterjee \& Lakshmanan, 2009

The latter example is most appropriate for the case study under review here, and is reflective of Harvey's assertion of a changing political economy more concerned with place rather than territory (Harvey, 1989a). The upgrading of an area's image through "flagship projects" enhances a locale's appearance while concomitantly attracting place-mobile capitalists (MacLeod, 2002). Thus, conventional entrepreneurial flagship projects have traditionally focused on the utilization of public-private partnerships (Harvey, 1989a), while more contemporary ones use tools such as tax increment financing schemes and business improvement districts (Weber, 2002) to develop "glittering office and hotel atriums...gentrified housing and aesthetically enchanting cultural districts" (MacLeod, 2002, p.605). The exploitation of postmodern design over comprehensive urban planning creates image over substance; the production and marketing of this urban image attracts other forms of development, providing the capacity to increase property taxes, local revenues, and employment growth (Harvey, 1989). Definitive entrepreneurial downtown regeneration projects include Harbor Place in Baltimore, Central Station in Chicago, Canary Wharf in London, and the renewal of New York City's Lower East Side (for an exhaustive list, see MacLeod, 2002, p.605). 
Building upon urban entrepreneurialism during the 1980s and 1990s is the competitive city model. Not entirely detached from urban entrepreneurialism, the competitive city reflects a shift in ideology that consolidates different forms of urban politics over the last three decades. Urban entrepreneurialism is not simply an interlude between the Keynesian-Fordist era of managerial city politics and that of global competitiveness, but rather a reflective part of urban competitiveness which acts as both a driver and catalyst toward creating dynamic governance structures. Kipfer and Keil's (2002) composition of the competitive city in Toronto consists of three ideological "axes": the entrepreneurial city, the revanchist city and the city of difference.

The entrepreneurial city largely reflects the economic, supply-side oriented accumulation strategies for inter-city competition outlined above. The revanchist city, derived from the French word revenche (literally meaning "revenge") reflects Smith's (1996) identification of the similarities between the perceived threat of the French bourgeoisie at the end of the $19^{\text {th }}$ century ${ }^{3}$ and the disturbing urban conditions in New York City in the mid-1990s. Created by neoliberal policy shifts, Smith's New York Cases study posits that governments had enacted revenge against the working class, feminists, immigrants, and environmental activists to create a "cleaner" New York City. Since then, revanchism has shifted from a political anomaly to that of a regulatory municipal policy, enacting ordinances which perpetuate crime control, the militarization of space, and sharper forms of socio-spatial segregation (Kipfer \& Keil, 2002). ${ }^{4}$ Smith states that urban revanchism is largely due to the effects of neoliberal globalization, and that such a phenomenon is not restricted to only American cities, but to all restructured urban geographies across capitalist states (Slater, 2009). Since Smith's initial thesis, researchers have identified the rise of urban revanchism in areas such as Glasgow (MacLeod, 2002), Britain (Atkinson 2003), and Rotterdam (Uitermark \& Duyvendak, 2008). Finally, the city of difference 
includes municipal policies which aestheticize difference (e.g. a vibrant multicultural city, a lively visual arts/music scene, or a self-professed "high tech capital) to support place-marketing, gentrification, and reformed land use and urban design policies into urban development strategies and economic competitiveness (Kipfer \& Keil, 2002, pp.235-237; see also Hall \& Hubbard, 1998; Smith, 1996).

The agents of the competitive city in many ways parallel the always-in-flux nature of neoliberalism, as the components are highly reflective of tighter global-to-local connections within capital accumulation. Smith's (2002) assertion that nationalist activities and functions are being dispersed to other scales (i.e. the global and local) reflects the manifestation of urban competitiveness. This shift has led to the restructuring of urban governments and continued restructuring of the urban scale due to changing forces of production. Urban centres have now become the leading incubators of the global economy through new urban forms and identities: first, through the development of new forms of social and economic restructuring largely influenced by neoliberal policy (i.e. entrepreneurialism, revanchism, and the city of difference); and second, through the rise of gentrification as a systematic, global urban strategy. As Kipfer and Keil (2002) succinctly summarize, "competitive city governance is...not reducible to the economic and social politics of neoliberalism. It represents a broader project of cementing and reordering the social and moral landscape of the contemporary urban order" (p.235, emphasis added). Thus, as Smith (2002) alludes to, Kipfer and Keil's ideological axes of the competitive city reflects a contemporary urban order through physical and social restructuring.

What is presented here is a reimagining of Harvey's (1989a) conjecture of place over territory; if the uprising of urban entrepreneurial governance structures in the 1970s and 1980s encouraged place-making, "flagship projects" and the attraction of globalized capital, the added 
ideologies of urban revanchism and the "city of difference" create the contemporary urban competitiveness regime, which represent a convergence of social and physical (re)production in attracting capital. The competitive city ideology is not so much a paradigm shift as it is a "significant novelty... (that) consolidates, formalizes, and magnifies trends in urban politics that have been operating in different forms over the last two decades" (Kipfer \& Keil, 2002; p.235). It is a transnational constitution or global systematic strategy which influences and perpetuates class differences through geographical restructuring.

While both Smith (2002) and Kipfer and Keil (2002) provide a concrete theoretical background to the rise of the competitive city, Chatterjee and Lakshmanan (2009) offer a pragmatic outlook that outlines the convergent factors leading to the rise of urban competitiveness outlined above. According to the authors, competitive governance transpires through material (knowledge-rich transportation and production technologies) and non-material (neoliberal ideologies, open trade regimes such as NAFTA, and financial innovations) technologies which shape the private, public, and social agents that contribute to urban restructuring. The process of capital accumulation is economically feasible through material technologies and institutionally feasible through non-material technologies (p.372-373). Such incidences are amplified by the continued weakening of Keynesianism, combined with the phenomenon of what Chatterjee and Lakshmanan outline as the "growing consumer demand for variety" (i.e. the growing demand for high quality goods; see p.373).

Such collective forces set the stage for a new economic arena in which the public (government), private (i.e. large development corporations/consortiums), and social (non-profit, non-governmental) sector design policies for, capitalize upon, and identify failures of, the competitive urban order, respectively. The consequential outcome of this contemporary order is 
the global organization of production systems driven by a knowledge-based economy, whereby globalized capital accumulation becomes ephemeral due to changing market prices, thus leading to municipalities engaging competitively with each other for such capital (Chatterjee \& Lakshmanan, 2009; see Fig.2). The agents of the competitive city must acquire new policy regimes (the entrepreneurial city), functions and identities (the city of difference), and human capital (the revanchist city) in order to promote itself on the world stage. The capacities to do so are largely dependent upon how a municipality uses and organizes space. This may be through infrastructure investment, earmarking sites for intensification and knowledge-based employment, systematic gentrification, and the assembling of land for lease in order to enable municipalities to "negotiate with international capital...to serve (sub)urban objectives" (Chatterjee \& Lakshmanan, 2009, p.382).

\subsection{Neoliberalism as Demonstration Project}

Although the manifestation of urban competitiveness through development projects and precedents is widespread and ubiquitous, the neoliberal transformation of governance structures have perpetuated development projects of various sizes and scope which seek to accumulate globalized capital. Drawing from Brenner and Theodore's theory of "actually existing neoliberalism", Swyngedouw, Moulaert, and Rodriguez (2002) provide extensive research on thirteen large-scale urban development projects (UDPs) in Europe. Their findings suggests that a convergence of macroeconomic policy combined with a new-state apparatus (i.e. competitive governance) has led to the planning and design of UDPs (see Fig.3). This phenomenon is outlined by the authors as the "new urban policy" (p.545), categorized as a response to the associated transformations of production and demand through both physical and socioeconomic 
development objectives: physical reconstruction and economic recovery work in tandem and are perceived as a simultaneous process; economic regeneration is achieved through spatially targeted schemes that promote private development; and capital has been mobilized to replace diminishing national funding and incentives.

The 12 UDPs outlined within Swyngedouw et al's research - which include mixed use areas, waterfront regeneration, business parks, and residential developments ranging in size from $345,000 \mathrm{~m}^{2}$ to over $1 \mathrm{~km}^{2}$ in cities such as Naples, Dublin, Athens, Bilbao, Berlin, London, and Rotterdam (see pp.549-551 \& pp.557-560) - represent a concerted effort by local and regional municipalities to reinforce their competitive position within the global economy. Three findings from Swyngedouw et al's research are particularly important to this paper. First, the development of UDPs act as a catalyst for implementing the new urban policy by establishing exceptionality measures within planning practice. They are developed toward upper- and middle-classes, appear less democratic and more elite-driven, accentuate socioeconomic

Figure \#2: The Forces, Agents, and Outcomes of Urban Competitiveness

\begin{tabular}{|c|c|c|}
\hline Change Factors & Change Agents & Outcomes \\
\hline 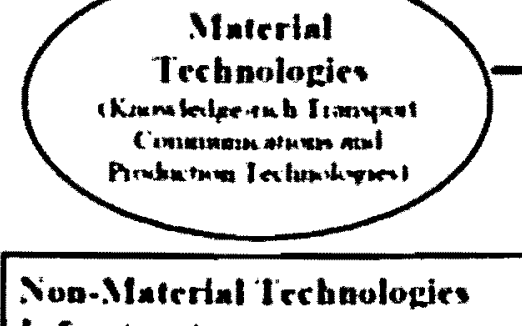 & & 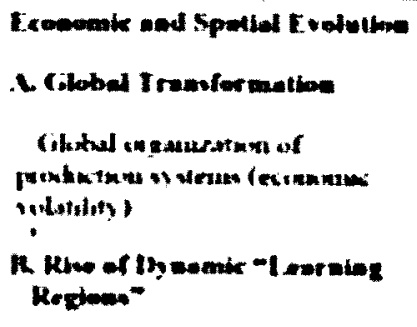 \\
\hline 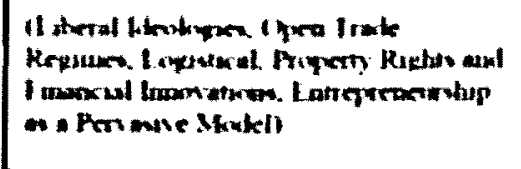 & orertial At & 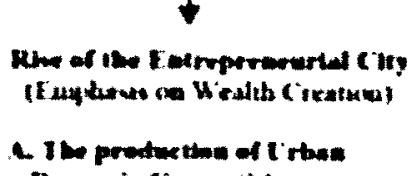 \\
\hline 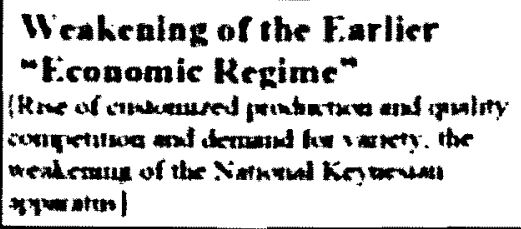 & & 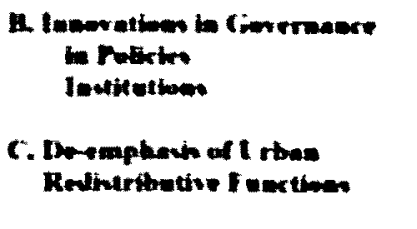 \\
\hline
\end{tabular}

Source of figure: Chatterjee \& Lakshmanan, 2009 
polarization through the working of real estate markets (i.e. systematic gentrification), and reflect a fundamental shift in the scale of governance. Second, the physical design of UDPs does not fit within the existing physical fabric or urban process of the city; their impact and connections to other areas within the city is considerably ambiguous despite their postmodern form and predominant size. And third - despite the generalized assumption of UDPs being market-led investments - a majority of the UDPs ( 10 of 13$)$ were state-led and state-financed, thus solidifying Weber (2002), McGuirk (2005), and Chatterjee and Lakshmanan's (2009) accounts that local governments - although contemporarily represented as one actor of change within the complex structures of neoliberal governance - have reoriented to become the organizers and facilitators of capital accumulation. Therefore, Swyngedouw et al's research represent the contextual embeddedness of neoliberal ideology (Brenner \& Theodore, 2002) while concomitantly representing the outcomes and political processes of competitive governance structures. As the authors succinctly proclaim:

UDPs are the very catalysts of urban and political change, fuelling processes that are felt not entirely locally, but regionally, nationally, and internationally as well. It is such concrete interventions that express and shape transformation in spatial political and economic configuration. They illustrate the actual concrete process through which postmodern forms, post-Fordist economic dynamics, and neoliberal systems of governance are crafted and through which a new articulation of regulatory and governmental scales is produced. UDPs are productive of and embody processes that operate in and over a variety of scales, from the local to the regional, the national, the European, and the global scale. (Swyngedouw et al., 2002, p.546)

The case studies represent the path-dependent and destructive nature of neoliberal ideology, leading to the production of "spaces of neoliberalization (Brenner \& Theodore, 2002). Moreover, the seemingly unassuming connotation of an urban development project represents a shift in planning ideology due to impeding influences of 


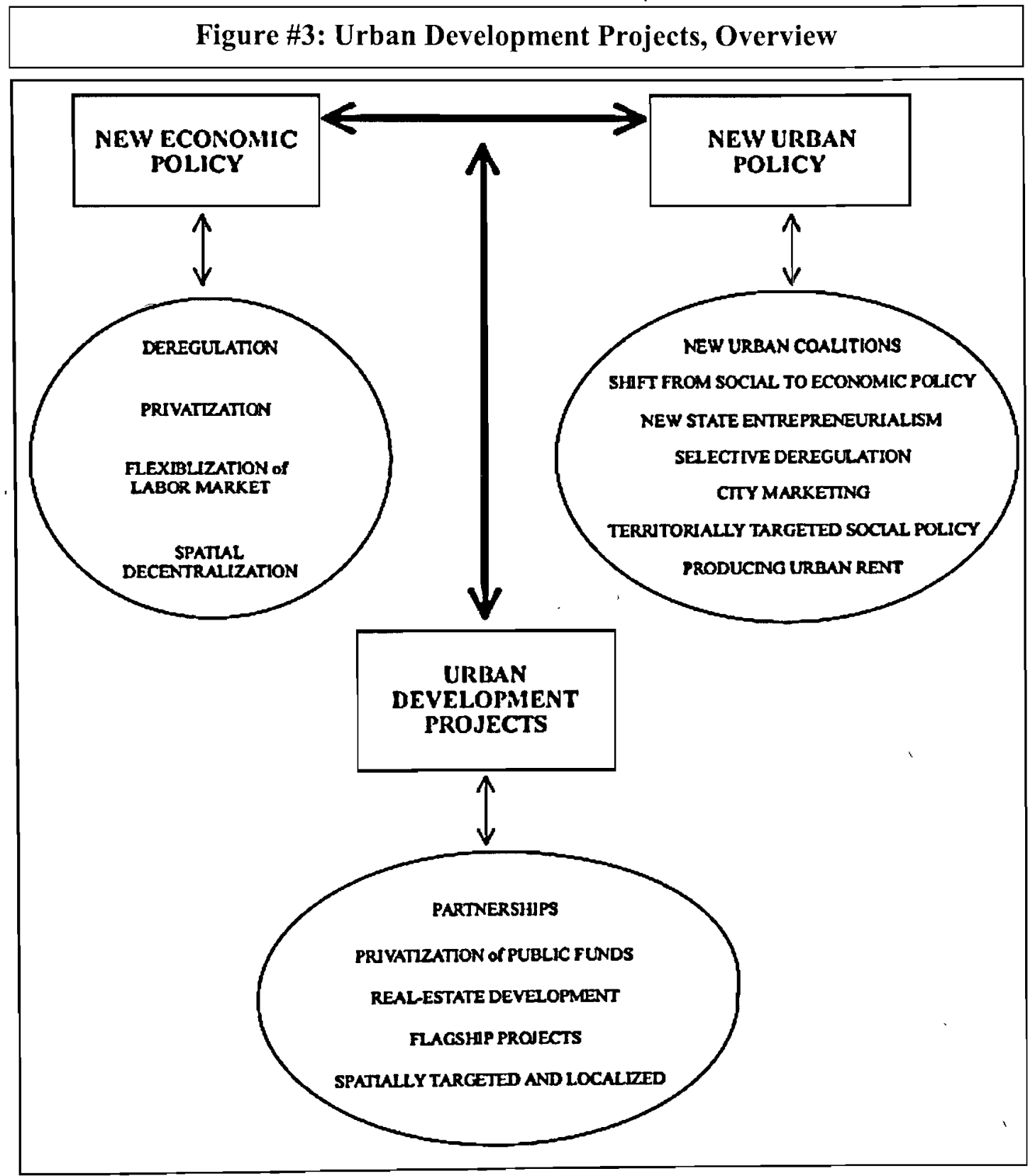

Source of figure: Swyngedouw et al., 2002

neoliberal localization and governmentality (Larner, 2000; Brenner \& Theodore, 2002), competitive governance systems (Kipfer \& Keil, 2002), and the rise of post-modern design and architecture that represents "symbolic" capital (Bourdieu 1977; 1984; Harvey, 1989b). As large scale development projects aim to represent the processes rooted in post-modernist urban design and architecture, they also reinforce Harvey's (1989a; 1989b) conjecture of place over territory through the ascension of post-modern urban 
design as an "anti-avant-gardist solution" (Harvey, 1989b, p.76). Symbolic capital is transformed into money capital, producing its proper effect and deployed deliberately to conceal the real basis of economic distinctions (Harvey, 1989). As Harvey states, "the production of symbolic capital serves ideological functions because the mechanisms through which it contributes to the reproduction of the established order and perpetuation of (class) domination remain hidden" (p.78-79). Harvey's stance rests on his conjecture that post-modernist architecture is "shamelessly market-oriented, because that is the primary language of communication in our society" (p.77). Thus, planning through postmodern "projects" has become the main strategy for economic growth - contrasting with the Fordist-inspired comprehensive plan - as the UDP case studies focus fundamentally on "design, detail, morphology, and aesthetics... (as it ) captures a segment of the city and turns it into the symbol of a new restructured/revitalized metropolis cast with a powerful image of innovation, creativity, and success" (Swyngedouw et al., 2002, p.562, emphasis added).

\subsection{But What about the Suburbs? The Rise of Neoliberal Suburban Governance}

As the North American suburb has typically been labeled as socially, culturally, and physically homogenous, its perceived secondary role is becoming increasingly problematic, as suburban expansion has outgrown some central cities since the end of World War II in areas of population, employment, and physical size (Addie \& Fiedler, 2008). Communication distances between suburb and city are increasingly shrinking through the "material technologies" of wired infrastructure, increased logistics, improved road systems, and increases built form and intensification within suburbia. Old city-suburb distinctions are breaking down into re- 
inventions of the simplistic notion of a city-suburb dichotomy (Bourne, 1996; Addie \& Fiedler, 2008). As Addie and Fiedler (2008) argue, "it is a recognition that with most Canadians now living in suburban areas...the suburbs form the essential backdrop for much of contemporary 'urban life', and therefore are widely discussed - without necessarily being the focus of analysis or discussion itself' (p. 3). Sieverts (2003) conceptualizes Addie and Fiedler's phenomenon through his concept of the "Zwischenstadt" (or, roughly translated to the "in-between city"), in which cities and suburban communities have been blurred due to intensified global, technical, and transportation connections. The Zwischenstadt is a continued search for the "pastoral romanticism and the comforts of the city" (p.7), similar to the visionary works of Ebenezer Howard, Le Corbusier, and Frank Lloyd Wright.

The apparent overpowering of the "old city", as Sieverts argues, essentially clouds our view of the reality of modern urban areas, where the historical city-core only constitutes a small fraction of the larger metropolitan area; there is a one sided love for the old city, Sieverts argues, which represses any love for suburbia. Although Sieverts' postmodern romanticism for the suburbs is ultimately utopian in scope, the importance of suburban areas to an agglomeration's historical center is indeed profound. This notion is particularly imperative in regard to (urban) governance literature, as theoretical discourses on neoliberalism and global cities focus inherently on downtowns and central business districts, as the suburbs are regarded simply as occurring autonomously from the above-mentioned conditions within central city cores (Addie \& Fiedler, 2008). Indeed, relationships between city and suburb have become increasingly complex due to the political and economic misalignments between processes of the classic "urban center" and the contemporary geographies of "urbanized regions". This is particularly relevant in regard to recent planning legislation within the Province of Ontario, as outlined in 
later sections of this paper.

Therefore, while the above sections have provided a summary of the capacities to carry out neoliberalized policy regimes rooted in spatially-focused strategies, much of this literature is primarily urban focused. This paper will argue, however, that the ramifications of urban neoliberalism stated above is analogous to the suburbs, and can be applied to the suburban landscape particularly within large metropolitan areas (as is the case for Markham's Langstaff Gateway). One of the fundamental aspects of this research is to critically analyze the introduction of new development paradigms within suburban areas, which act as catalysts for capital accumulation and socioeconomic polarization while exploiting postmodern development as "symbolic capital". This phenomenon is executed through the implementation of the alwaysin-flux postmodern planning ideology of new urbanism combined with the systematic utilization of gentrification (particularly "new-build gentrification"; Cf. Davidson \& Lees, 2005; Smith, 2002).

An increasing body of literature has dedicated itself to the connections between suburbanization and the macroeconomic forces of neoliberalism. A majority of suburbanneoliberal discourse stems from the State of New South Wales, Australia, particularly within the Sydney Metropolitan Area (Cook \& Ruming, 2008; McGuirk, 2005; Ruming, 2005). This is useful for the case study under review here, as the political and geographical character of the Sydney Metropolitan Area is similar to that of the Greater Golden Horseshoe.

McGuirk's (2005) critique of Sydney's new regional strategy in 2004 outlines a "hybrid" approach to neoliberal governance; while the strategy is rooted in neoliberal tendencies (guided by a triple-bottom-line agenda of competitiveness, sustainability, and livability; see p.66), it is underpinned by a myriad of government interventions, including the normalization of market 
rules, development taxation, and regulatory restrictions. McGuirk, however, is quick to note the impeding challenges of the new strategy, proclaiming that a return to "corporatist" form should be avoided and that increased public participation is meaningful. Ruming's (2005) case study of the master planned Town of Warnervale is similar to McGuirk's hybrid governance conjecture. The policies of the Warnervale Town Centre Master Plan - a mixed use development which utilizes the planning and design principles of new urbanism - serve two seemingly contrasting objectives: to alter the residential market in order to support social democratic objectives; and to attract free enterprise provision of services for future residential population (p.88). Ruming outlines that, analogous to McGuirk's case study, the creation of a master plan and a local government interested in service provision and infrastructure represents an inherent opposition to neoliberal tendencies. Yet, through the constitution of partnerships with various private institutions and an increasingly neoliberal Government of New South Wales, the project represents a "contingent expression" of neoliberal policy. Ruming concludes that Warnervale represents a contextually specific expression of actually existing neoliberalism through varying scales of embeddedness (local, regional, state) and governance actors. The Wamervale case study represents "the multiple agendas and desperate trajectories pursued by localist and regionalist authorities that produce contingent forms of urban governance in interurban contexts" (Cook \& Ruming, 2008, p.220).

Cook and Ruming's (2008) research further perpetuates the findings in Ruming's initial case study (albeit at a broader scale) by comparing two large-scale residential property developments - the Warnervale Town Centre (as outlined in Ruming, 2005) and a former Commonwealth Department of Defense site in St. Mary's. The authors' findings suggest that each development offers vastly different translations in regard to the hybridity between state and 
market interaction. Thus, given neoliberalism's uneven path-dependency, each project outlined above - including that of Swyngedouw et al (2002) - is representative of the complexity between various (suburban) governance scales and structures. Furthermore, the above examples (particularly in Sydney) outline that neoliberalism is not an all-encompassing hegemony, but rather a constantly changing ideology with various outputs, rather it be at the state, regional, urban, or suburban level. Above all, through the various forms of neoliberalization outlined above, neoliberalism can be regarded as both a market and political project, although emphasis on the market is not always a foregone conclusion (Larner, 2005). As Larner (2005) states: "rather than analyses that continually re-inscribe the inevitability of marketisation and individualisation, we need to foreground contestation and contradictions (p.17). Thus, in following Larner's statement, this paper will outline two devices in which neoliberal policy manifests: the systematic use of ("new-build") gentrification and the planning ideology of new urbanism.

Following a summary of the above-mentioned processes, this paper will outline the planning, design, and development of the Langstaff Gateway. An argument is posited that the Langstaff Gateway utilizes aspects of competitive urban governance structures, the design principles of new urbanism, and the use of systematic gentrification, but also represents a "hybrid" form of neoliberal governance analogous to the Australian case studies.

\subsection{Gentrification: From Marginal Oddity to Systematic Strategy}

A large body of literature regarding the "traditional" forms of gentrification has developed extensively since Glass's (1964) coinage of the term over forty years ago (see Caulfield, 1994, 2005; Hamnet, 2000; Ley, 1987, 1996; Smith, 1987, 1996, \& 2002). However, 
the introduction of "new-build residential developments" (Davidson and Lees (2005; p.1165) where partially or completely vacant land is planned as a new residential neighbourhood - has led to a reimagining of the term within the context of $21^{\text {st }}$ century urban planning literature. "New-build gentrification", a mass-produced "planning blueprint" linked to global urban strategies and neoliberal urban policy, is described as gentrification through developer-led economic capital. This is opposed to the traditional middle- and upper-class upgrading of a single dwelling within a working-class neighbourhood (Davidson \& Lees, 2005; see also Boddy, 2007; Davidson, 2007; Smith, 2002). New-build gentrification also places a political-economic lens to the term. Elite actors, which include entrepreneurial politicians, planners, bankers, and developers, drive gentrification, with response from existing residents being met with either broad resistance or quiescence (Davison and Lees, 2010; Niedt, 2006).

Davidson and Lee's initial research on London's Riverside represents new-build gentrification's "renaissance", as designer apartment blocks built within the neighbourhood by corporate developers seemingly reflected the traditional gentrified landscapes of restored Victorian terraces. The authors argue that this is not simply a case of "residential rehabilitation", but rather a politically-motivated attempt to attract the upper-class elite into otherwise stagnant or derelict neighbourhoods. New-build gentrification is also largely utilized by competitive governments. Mills' (1988; 1993) case study on Vancouver's Downtown South neighbourhood during the mid- to late 1990 s is ultimately reflective of a new-build gentrification pattern that, although championed by architects and developers, was led by the local state (see Fig.4). The Vancouver case is essentially an early example of third-wave gentrification, as state intervention and the large scale deployment of capital ultimately led to the massive displacement of lower class residents In recent years however, as Davidson and Lees (2010) suggest, new-build 
gentrification has become even more intertwined with government interventionism, largely sold through the discourse of "mixed communities". Indeed, gentrification has become a positive public policy tool when linked to urban planning practice that champions socially mixed, mixedincome, and mixed-tenure neighbourhoods. This is most notable through the United States Housing and Urban Development's HOPE VI (Home Ownership and Opportunities for People Everywhere) Program, where urban policy has been used to socially mix public housing in order to break down any perceived notion of social isolation; the results of this program has essentially been significant displacement (Davidson \& Lees, 2010; see also Hanlan, 2010). This style of planning has also been given heavy credence within the City of Toronto, as past social housing projects such as Regent Park and Lawrence Heights are currently being revitalized analogous to the HOPE VI programs. Due to the Toronto developments being so recent, however, their ramifications have yet to be tested. The intent of this paper is not to critically analyze such developments. What such case studies do outline, however, is that the link between "positive" gentrification policy and best practices to urban planning largely go hand in hand. Therefore, a conjecture is made here that the ideology of new urbanism can certainly parallel with positive gentrification policy, particularly within suburban areas given that a majority of new urbanist projects materialize within such locales.

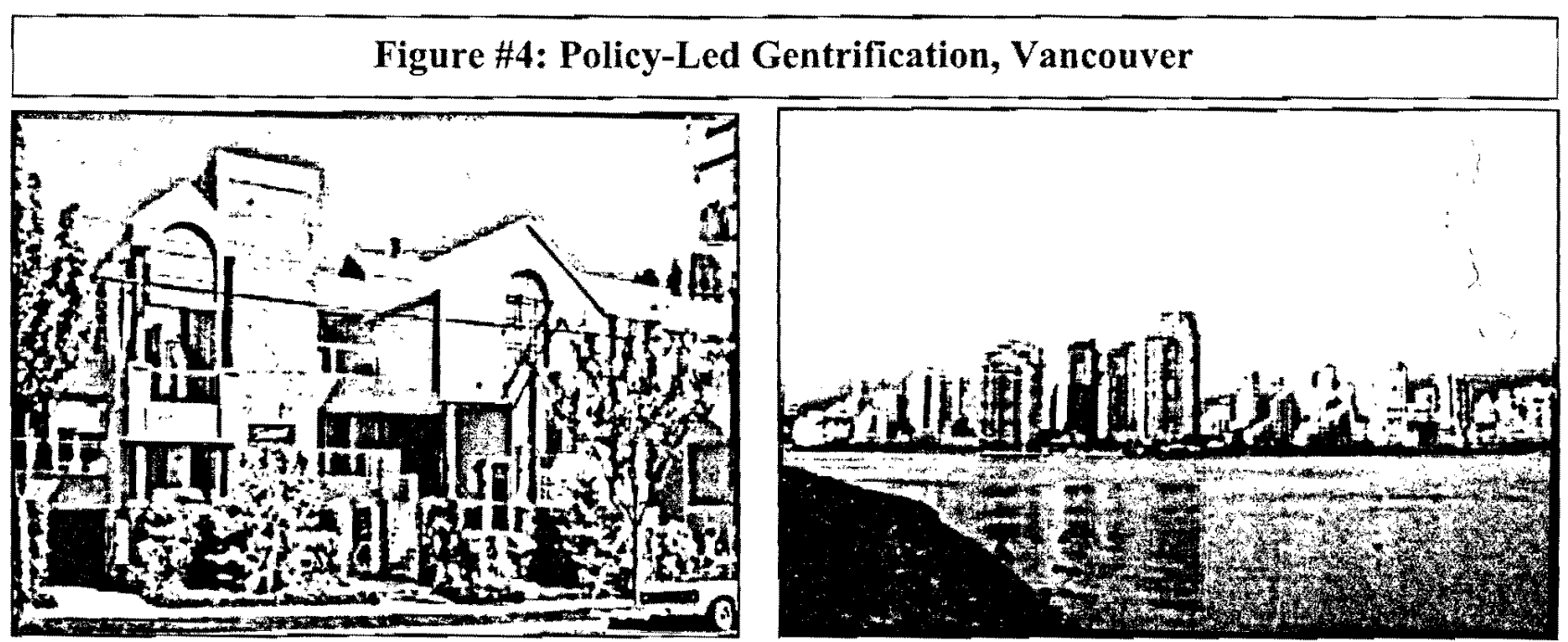


Thus, given the above examples, this phenomenon is logically tied to the emergence of third-wave or post-recession gentrification beginning in 1993 This term began to challenge the historical continuity of traditional gentrification patterns to facilitate a more contemporary approach, as development patterns began to take a myriad of forms not recognized with the traditional term (Hackworth \& Smith, 2001; Lees, 2003). Therefore, it seems natural that the term "new-build gentrification" has led to speculation as to whether the phenomenon of newbuild developments classify as "gentrification" at all (Boddy, 2007). The conventional term itself has never been consensual (Smith, 1996; Hamnet, 2000): "new-build gentrification" does not reflect the traditional single gentrifier who renovates old housing stock (Caulfield, 1994; Hamnet, 2000; Ley, 1996), nor fully reflect Smith's (1987) supply side (or "rent gap") theory (although if new-build gentrification were to be placed on a continuum between the two, it would certainly sit closer to the rent gap theory; see Davidson and Lees, 2010). ${ }^{5}$ Rather, new-build gentrification involves larger forces of global capital investment through development industries that have the capacity and capability to deploy such capital into vacant pieces of land - primarily through residential estates and high-rise condominiums. Such developments are sequentially marketed toward higher-earning income groups who buy into a commodified landscape branded as an alternative urban lifestyle, thereby exploiting the diversity of downtown living initially "pioneered" by first-wave gentrifiers (Lambart \& Boddy, 2002; Zukin, 1991). This phenomenon has been regarded by Boddy (2007) as "stretching the conceptual boundaries of gentrification" (p.97), and referred to as simply the remaking of an urban landscape through a complex process of global capital investment (Davidson, 2007; Smith, 2002).

Davidson (2007) however, argues that new-build developments are indeed gentrification by providing four indicators which are applicable to the traditional and "new-build" term. He 
argues that both forms: upgrade the social composition of the neighbourhood; result in a significant landscape change motivated by a demonstration of cultural identity; involve a significant reinvestment of capital into previously devalorised space; and generate processes of replacement and displacement (p.494). In regard to the final indicator, Boddy (2007) argues that the new-build process induces indirect replacement and displacement, and therefore does not constitute the core phenomenon of classic gentrification: direct physical displacement. This argument has since been contested by Davidson and Lees (2010) through their case research on the communities of Brentford, Wandsworth, and Thamesmead in London. The authors believe that although existing residents within the above neighbourhoods are perhaps not directly displaced, phenomenological understandings of "home" and "neighbourhood" have been dismantled through new-build gentrification, thereby mirroring the aspects of physical displacement: "the forced disconnection from familiar place and the (phenomenological) relocation into a new urban social context" (Davidson \& Lees, 2010, p.405)

Regardless of this dichotomy of definition and semantics, Boddy (2007), Davidson (2007) and Davidson and Lees $(2005 ; 2010)$ concomitantly agree upon Smith's (2002) assertion that "gentrification is now a revanchist, neoliberal urban policy agenda that has stretched around the globe" (in Davidson, 2005, p.490). Smith argues that investment in capital production has taken precedence over social reproduction (Keynesianism) in advanced capitalist cities, thereby "globalizing" the incidence of gentrification past the traditional small scale occurrences most notably recognized in the housing market of "command-center cities" (Smith, 2002, p.427). New-build developments, therefore, encapsulate the connection between gentrification and the larger forces of globalization and neoliberal urban restructuring quite intrinsically. Traditional gentrifiers, who have been speculated as the sole subjects to foster this connection between 
gentrification and globalization (Butler, 2002; 2007; Rofe, 2003), have in turn transformed into the active agents, shapers, and consumers of globalized capital facilitated by real estate (i.e. major developers) and bureaucratic (i.e. governments) actors. This has led to the indirect displacement of adjacent neighbourhoods of lower classes and income groups (Davidson, 2007; Niedt, 2006).

Returning to Brenner and Theodore's (2002) assertion of "actually existing neoliberalism", new-build gentrification reflects the contextual embeddedness of neoliberalism, as metropolitan regions, the authors argue, have become significant areas for neoliberal policy experiments which include place-marketing, urban development corporations, public-private partnerships, property redevelopment schemes, city boosterism, and social control. Such policy experiments conceptualize city spaces as an area for market-oriented economic growth and the division of social classes in localized areas. Gentrification is one of many "mechanisms" of neoliberal localization outlined by the authors (p.23-25), as the destruction of working class neighbourhoods make way for speculative development including the "construction of largescale megaprojects intended to attract corporate investment and reconfigure local land use patterns" (Brenner \& Theodore, 2002, p.24). While perhaps not explicitly referring to the process of new-build gentrification, Brenner and Theodore's explanation of embedded neoliberalism certainly builds upon the assertions made by Davidson and Lees (2005; 2010), Smith (2002), Davidson (2007), and Boddy (2007).

Literature regarding new-build gentrification has typically focused on UK cities (Boddy, 2007; Davidson, 2007; Davidson \& Lees, 2005), although Mills' (1988; 1989; 1993) earlier Vancouver case study and the American HOPE VI program, among others (see Warde 1991), were regarded as watershed moments in regard to new-build literature (Davidson \& Lees, 2010). 
Furthermore, although conventional gentrification patterns have been studied under suburban (Hackworth \& Smith, 2001; Robson \& Butler, 2001) and even rural (Phillips 1993; 2002) landscapes, new-build gentrification, much like the rhetoric of competitive governance, has yet to be fully analyzed under such land forms. Boddy's (2007) Bristol case study touches on the subject, while Davidson and Lees (2005) go so far to argue that the "gentrification blueprint" connected to new-build development encroaches into "first world suburban and rural areas" (p.1167) as the dichotomy between the urban and rural continually diminish. There is, however, a small yet important amount of research regarding new-build gentrification in the suburbs; Niedt's (2006) case study of Dundalk Maryland represents a key piece of research in regard to suburban new-build gentrification. Findings suggest that developers and the neoliberal state will find popular support for policy-led gentrification within politically divided deindustrialized municipalities like Dundalk. Although Niedt's case study focuses on the racial undertones associated with Dundalk, ${ }^{6}$ his research also outlines an important conclusion that is relevant to this paper: the rebirth of suburban neighbourhoods provides evidence of new-build gentrification's success as it relates to neoliberal ideology and competitive governance. Niedt states that, "as a private-sector strategy, (gentrification) is compatible with reductions in government spending that have become broadly popular in the American suburbs; the state intervention of third-wave gentrification is acceptable insofar as it facilitates private development" (p.104). Thus, similar to the urban-based case studies outlined above, there is certainly speculation to suggest that new-build gentrification is or will be occurring within suburban locales; this is especially true when coupled with (sub)urban planning paradigms such as new urbanism. Indeed, its applicability will be analyzed and tested through the case study outlined below. 


\subsection{New Urbanism: Context and Criticisms}

The planning and design movement of new urbanism reflects one of the leading social and material contemporary paradigms within suburban planning theory and practice. Stemming from the work of Jacobs (1961), Krier (1978), and Lynch (1960), new urbanism encapsulates old forms and principles of town development reimagined within the $21^{\text {st }}$ century. With the establishment of smart growth 7 principles in Canada and the United States by the late 1990s, new urbanism became the panacea for ailing all that was wrong with suburban development (Grant, 2005; Harvey, 1997). Correspondingly, the development of the Congress for New Urbanism $(1993)^{8}$ - led by new urbanist planners Andres Duany, Jeff Speck, Elizabeth Plater-Zyberk, and Peter Calthorpe - brought the ideology of new urbanism to the forefront of North American suburban planning practice. The common principles of the new urbanist movement, according to the Charter of New Urbanism (1996), include the allocation of mixed land uses and mixed housing types, compact form, an attractive public realm, pedestrian-friendly streetscapes, defined centres and edges, and a variety of transportation options (Grant, 2005; Hirt, 2009). Furthermore, new urbanism typically - but not always - favours the use of traditional architectural style, design patterns, and street layouts. New urbanism claims to address the physical and social failures of modernist styles of planning (particularly that of Urban Renewal and the Garden City movement), as well as the homogenous, standardized style and design of post-World War II suburbs (i.e. sprawl, auto-dependency, and gridlock) through the use of "premodern" forms (Hirt, 2009).

The rise of new urbanism coalesced through a multitude of "new urban" development paradigms which have since shaped the Charter of New Urbanism: traditional neighbourhood design (i.e. "neo-traditional" design), which focus on vernacular or classical architecture; transit- 
oriented development (TOD), which focus on public transit hubs linked to regional systems; and the urban villages movement in Europe, which place emphasis on self-sufficiency (i.e. mix of housing and employment) and brownfield (re)development (Grant, 2005).

Yet, although new urbanism is considered widely as the major postmodern paradigm in planning theory and practice - the cultural metanarrative which represents the historic shift away from the doctrine of modernism - many have critiqued otherwise (Sorkin, 2007; Harvey, 1997; Hirt, 2009). The tenets which outline new urbanism seemingly represent a shift from the comprehensively planned, scientifically prepared, and technologically efficient master plan embraced by modernist thinkers such as Le Corbusier and Ebenezer Howard. This postmodern logic embraces a multiplicity of views, spontaneity, and choice - yet this is ultimately where new urbanism falls short. Hirt (2009) outlines the "pre-industrial" tenets proclaimed by Krier in which new urbanism follows: ideals of maturity such as historicism and contextualism; proximity and connectivity through mixed use and planning at the pedestrian scale; and complex dialogues of form and inclusiveness. The implementation of such tenets, however, is inherently based on modernist perspectives such as hierarchy of form, imposing limits on growth, and strict architectural guidelines. Lee and Ahn's (2003) research solidifies Hirt's conjecture through a comparison of the garden city-inspired Radburn, New Jersey and Kentlands, Maryland, one of the first new urbanist developments within the United States. Their findings suggest that, while their prescriptions may be inherently different, they are comparable in terms of walkability, mixed land uses, and pedestrian connectivity. Sorkin (2007) outlines the ideological convergence between new urbanism and utopianism, as both: invest in a correct and universal architecture; are hostile to anomaly; present extremely constrained relationships to human subjectivity; and have an agenda that embraces the idea of social justice yet has no theory in 
providing it (p.176). Similarly, Forsyth and Crewe (2009) outline many correlations between the Charter of New Urbanism and the CIAM-inspired Athens Charter (1933), as both criticize sprawl, advocate regional approaches to planning, and propose multifunctional cities. The differences are in the particulars, however, as new urbanism reverts back to the importance of locality and extrapolation rather than the use of contemporary, universal design guidelines. Hirt summarizes the above statements quite succinctly:

The new urbanist plurality of styles and uses has an almost paradoxical quality to it. It is required, yet restrained. Regulations are put in place to mandate it, but also to control it. Design codes postulate it, yet limit it to a few acceptable styles; zoning codes ordain it, yet prevent it from spreading beyond the few preselected areas. The outcome does not look quite like modernist no-frills architecture, but it has little to do with the "medley of the [traditional] neighborhood." It is premised on rejecting modernist homogeneity but reflects a modernist dedication to certainty and predictability. (Hirt, 2009, p.267)

Thus, new urbanism can be regarded as a "soft" form of urban renewal, wholly entrenched within modernist-utopian viewpoints in tandem with exploiting the urban design schema of post-modernist architecture (Sorkin, 2007). One factor that may separate new urbanism from its modernist paradigms is simply the processes of postmodernist urban design. As outlined by Harvey (1989b), the use of "symbolic capital" is utilized to create "communities" which revert back to the locality of eighteenth and nineteenth century neighbourhoods, yet are rooted within the cultural realm of neoliberal localization and the embodiment of "family values" (see Sorkin, 2007, p.174). The fact that new urbanism relies solely on the aesthetic of a community reinforces and proliferates the dogma of physical determinism, where ideologies such as urban renewal - which had the best of social intentions - have since been belligerently critiqued and thus proven not to work (either realistically or ideologically). Thus, the process of (sub)urbanization should reflect "a group of fluid processes in a dialectical relation to the 
spatial forms which they give rise and which in turn contain them" (Harvey, 1997, p.3). Focusing on such a process, as Harvey argues, will proliferate the struggle for the socially just and politically emancipatory city, rather than complying with the imposed notion of uncontrolled capital accumulation. As the case studies outlined below will prove, this ideology has yet to take form.

Multiple critiques on the implementation of new urbanism are also quite myriad, particularly in regard to the affordability, authenticity, diversity, and equitability of the projects (for a comprehensive list, see Grant, 2005, pp.180-192). While new urbanism claims to represent a "social synthesis" approach (Krier, 1991) - and not merely another project ultimately reliant on physical determinism (Harvey, 1997) - Grant, among others (see also Gause, 2002) have reported that very few new urbanist communities include affordable housing, and that most reveal a premium for new urbanist developments. This is perhaps notable once again through the American HOPE IV Program, where troubled affordable housing projects have been razed in order to usher in a renewed sense of optimism via new urbanism (Hanlan, 2010). Although generally championed by policy makers and public officials, the HOPE IV case studies outlined in Hanlan (2010) have seemingly yielded to private redevelopment initiatives, leading to (newbuild) gentrification pressures at the expense of areas initially planned for lower socioeconomic demographics (see Davidson \& Lees, 2010). In doing so, HOPE IV perpetuates the dynamics of neoliberal (competitive) governance, and ultimately raises further doubts about the program's success.

The authenticity of new urbanism has also been challenged. Grant suggests that new urbanist projects lack the social and physical diversity of "real" towns. The aesthetic and manufactured touches of new urbanism ultimately mask the social homogeneity within the larger 
urban environment, leading exclusively to residential, car-oriented, and class-uniform urban patterns. What perpetuates this urban form is developers "cherry-picking" some of the easier-toimplement design elements of new urbanism (i.e. lane-based housing), while purposely excluding the radical ones (i.e. mixed use, mixed housing, mixed class and race) in order to conform to the wider market and reduce financial risk (Grant, 2005; Hirt, 2009; see Fig.5). Perhaps most importantly, however, is how the paradigm of new urbanism frames a social ideology of defining "community", which caters exclusively to a middle- and upper-class agenda that is ultimately suburban, with no regard to urban impoverishment (simultaneously excluding social, women, and LGBT rights, to name a few). The irony here is that the desire for "community" is traditionally rooted in class devaluation, racism, and ethnic chauvinism, thereby signaling and defining other groups as simply that: the other. Thus, the utilization of the communitarianism ethic for the basis of new urbanism acts "as a barrier rather than facilitator of progressive social change" (Harvey, 1997, p.3), thereby further dividing the lower class from the upper- and middle-class through mobilizing ("symbolic") capital toward the latter. As Sorkin (2007) suggests, the problem is fundamentally rooted in the Western ideal of "having too much"; it is a mismatch between existing economic privilege and inappropriate spatial organization. And as Harvey (1997) concomitantly states, "new urbanism builds an image of community and a rhetoric of place-based civic pride and consciousness for those who do not need it, while abandoning those that do to their 'underclass' fate" (p.3).

Grant's review of new urbanism suggests that democracy in regard to public consultation is inherently weak, as the visioning process for new neighbourhoods are often represented by converts and believers of new urbanism, thus not fully representing the community at large. One ideological paradox within new urbanism is also the designers' reluctance (and oftentimes 
hostility) to embrace change in urban form or character from public consultations or elsewhere. This reinforces Sorkin's and Hirt's inference that, although new urbanism is meant to reflect the postmodern metanarrative, it is ultimately entrenched in the modernist ideal that the professional knows best. Furthermore, from a strictly Marxist perspective, new urbanism is regarded as the latest incarnation of (sub)urban capital accumulation, fueling the capitalist growth machine when production lags, thus sustaining economic activity and the market.

In terms of equitability, new urbanism ostensibly rejects modernist urban renewal housing projects by integrating the poor into the wider urban fabric. Quality design and architecture is used to de-stigmatize poor households, as new urbanism is regarded as a social project as much as a physical one, which allows the poor to assimilate into the culture of middle classes (Grant, 2005). The often perverse notion, however, is that the integration of the middleclass with the poor acts as a civilizing agent through which new urbanism is its device (Duany, Plater-Zyberg, \& Speck, 2000). To exacerbate this statement, the major proponents of new urbanism seemingly encourage the use of systematic gentrification, which is viewed upon as a sign of positive renewal and revival for neighbourhoods (cf. Niedt, 2006).

The above critiques outline the disjuncture between new urbanism's theory and practice. Given that the Langstaff Gateway is one such manifestation of new urbanism which has yet to be built, the above-mentioned ramifications are indeed possible. However, The Town of Markham has witnessed such ramifications in prior new0urbanist communities. Thus, the following section will outline the various new urbanist paradigms that Markham has built, which simultaneously serve as useful examples in regard to new urbanism as an ideology, as well as a fundamental background leading up to the case study under review here. 


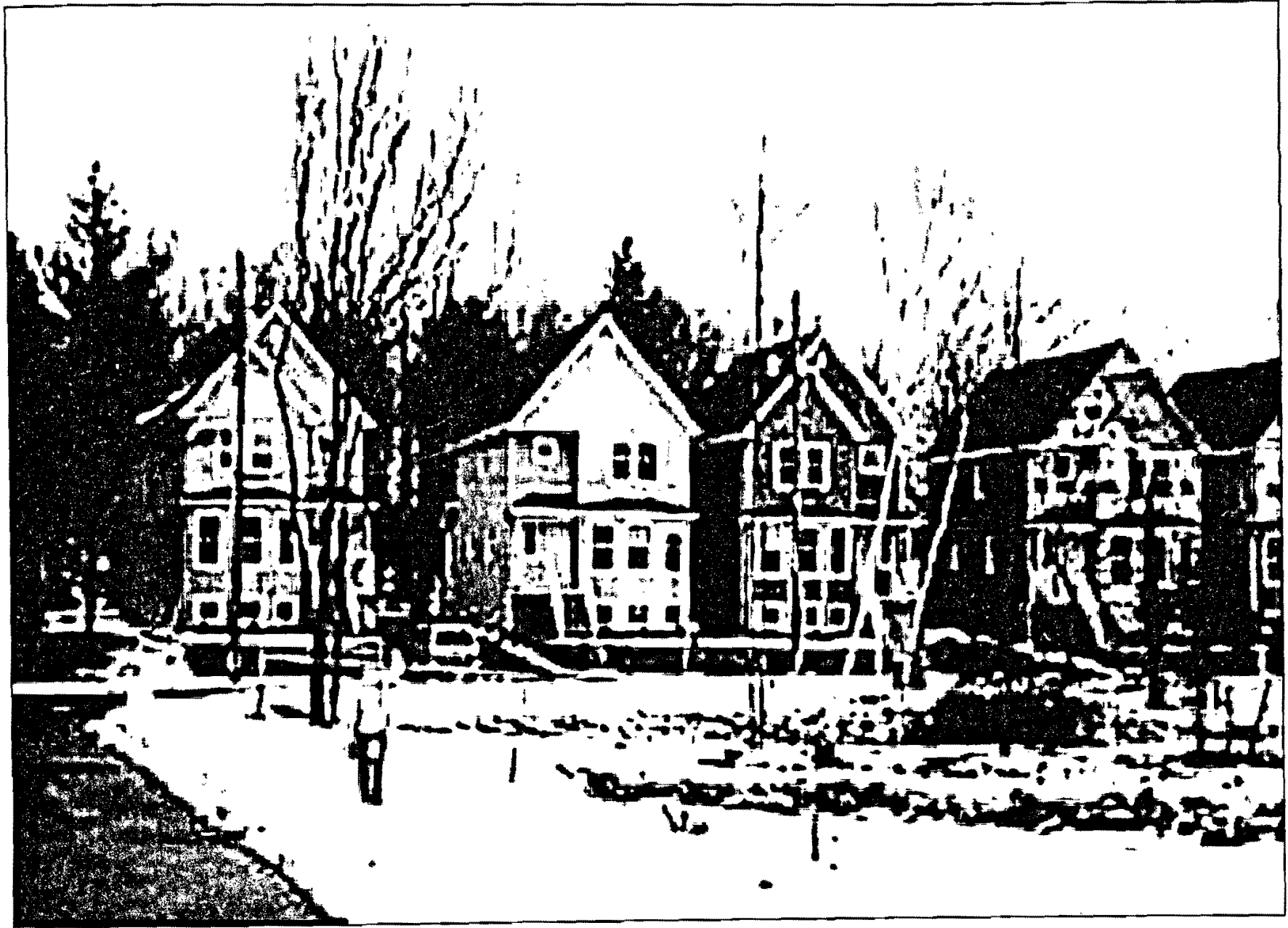

This Halifax subdivision reflects some aspects of new urbanism such as front porches and rear-based garage doors, but ultimately encompasses typical post-war suburban development. (Source of image: Grant, 2005) 


\section{Chapter 4: Background and Context}

\subsection{Markham's New Urbanist Demonstration Projects}

With the apparent success of Seaside, Florida and Kentlands, Maryland - two precedentsetting new urbanist projects in the United States - the concept of new urbanism grew in Canada during the 1990s. Professional organizations continued to promote new urbanism as the overarching discourse for contemporary planning practice and sustainable development (Grant, 2005), while earlier successes of postmodern neighbourhood designs like the St. Lawrence Neighbourhood in Toronto had already gained credibility during the 1970s (see Hulchanski, 1990). Canadian new urbanism has generally followed the American model, as new urbanist proponents such as Duany and Calthopre have played major roles in offering advice and guidance to Canadian municipalities, thus shaping the Canadian perspective. However, unlike the United States - where new urbanism relied upon developers to apply covenants - new urbanism in Canada was largely influenced by shifts in municipal planning policy (Grant, 2005).

This is perhaps best represented in the Town of Markham, one of the fastest growing municipalities in Ontario. Located within the upper-tier municipality of York Region, the Town of Markham covers $212 \mathrm{~km}^{2}$ and abuts Toronto to the northeast. The Town has a population of roughly 300,000 and a rather large employment base of company headquarters (approximately 400). The Town also consists of over 900 high-technology and life science companies, selfproclaiming itself as "Canada's High-Technology Capital" (Town of Markham, 2011). Eleven secondary plans incorporating the principles of new urbanism were approved in Markham between 1994 and 1997, making the Town North America's largest concentration of neotraditional design projects, all of which trump Seaside and Kentlands in size and character (Gordon \& Temminga, 2002; see Fig.6). The Cornell neighbourhood - the first planned new 
urbanist community in Markham - has been regarded as one of two precedent-setting new urbanist neighbourhoods in Canada (the other being McKenzie Town in Calgary; see Grant, 2005, pp.157-164). The 980 hectare (2,400 acre) swath of land was once owned by the Province of Ontario after it expropriated the land in 1973 for a potential airport (Gordon \& Temminga, 2002; Skaburskis, 2006). Planned in 1989 as an affordable housing demonstration project spearheaded by the Province to showcase what private developers could do to improve affordability of housing types and tenures, the project was not well-received, and prompted a new search for competitive design ideas. Planned in consultation with Duany and Plater-Zyberk (1992) and supported by the Region of York (Markham's regional planning authority), Cornell was draft approved for 10,000 units and a population of 30,000 . However, due to deregulation and undercutting of public assets in 1995 by the newly elected Progressive Conservative provincial government, the lands were sold to a private development consortium in 1996 (Moore, 2010). Although the first phase of Cornell was viewed as a financial and structural disaster (Moore, 2010), it has since been regarded as a successful test site to both developers and the municipality at developing and marketing new urbanist housing products. Thus, Markham began its endeavour as a new urbanist municipality, making new urbanism a codified strategic planning approach and promoting itself as "Canada's Centre of Excellence for New Urbanism".

The branding of new urbanism in Markham was largely a conscious political decision in an attempt to influence market actors (i.e. developers and builders) to accept and adhere to such principles (Moore, 2010). As Moore (2010) states, "Cornell has the power to in part, influence everything else that gets built in the GTA" (pp.105-106). What is particularly important to note, however, is the diversification and alteration of new urbanist projects and principles throughout the Town. While the formulaic characteristic of Cornell (particularly that of rear-lane based 


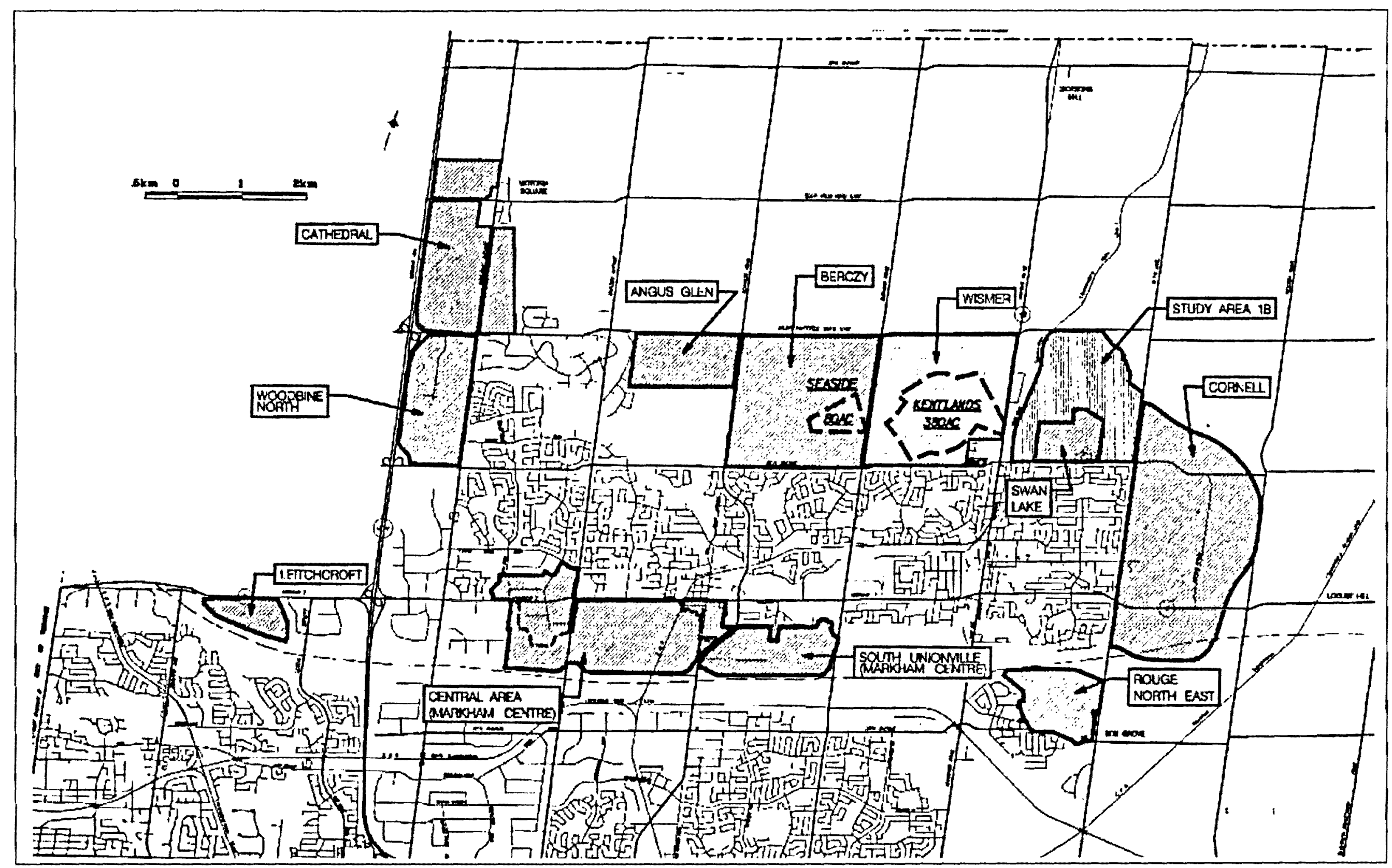


design; see Fig.7) was what maintained its uniqueness and price premium within the local marketplace, "developments and builders were cognisant of the need to diversify the Cornell 'product' to maintain competitiveness in an increasingly normalizing market for new urbanist inspired design features" (Moore, 2010, p.106, emphasis added). While the political framework embraced the new urbanist doctrine presented within Cornell, market actors have been hesitant to fully embrace the design schema of new urbanism as seen within the Cornell development, even with a rather prescriptive new urbanist by-law for Markham's "urban expansion area" passed in 1996 (Grant, 2009). Neighbourhood developments after Cornell - which include projects with names such as Berczy Village, Angus Glen, Cathedraltown, and Wismer Commons (see Fig.6) were built adjacent to conventional suburban neighbourhoods) circa the 1980 s (i.e. traditional loops, cul-de-sacs, and single-detached housing). However, a mantra of "post-war suburbia" exists between the successive new urbanist projects after Cornell, as such developments have manifested into a hybrid of new urbanist and conventional styles of suburbanization. Figure \#8 compares the new urbanist neighbourhood of Wismer Commons to its southern adjacent "conventional" subdivision built in the early 1980s. Although there are clear differences in street pattern as well as the use of rear-lane based housing on the arterial roads of the Wismer Development (inset photo \#1), the majority of the housing remains consistent to conventional post-war suburban neighbourhoods (i.e. single detached with large driveways and front lawns; see inset photos \#2 \& \#3) while a majority of land use for Wismer is allocated for low density residential uses (see Fig.1, Appendix A). Thus, developments since Cornell consist of handpicked design and land use elements of new urbanism that are suited toward the market while perhaps purposely - omitting significant elements which play a key role in "urbanizing" the suburbs, particularly that of mixed use and neighbourhood-scaled retail. The private market had 


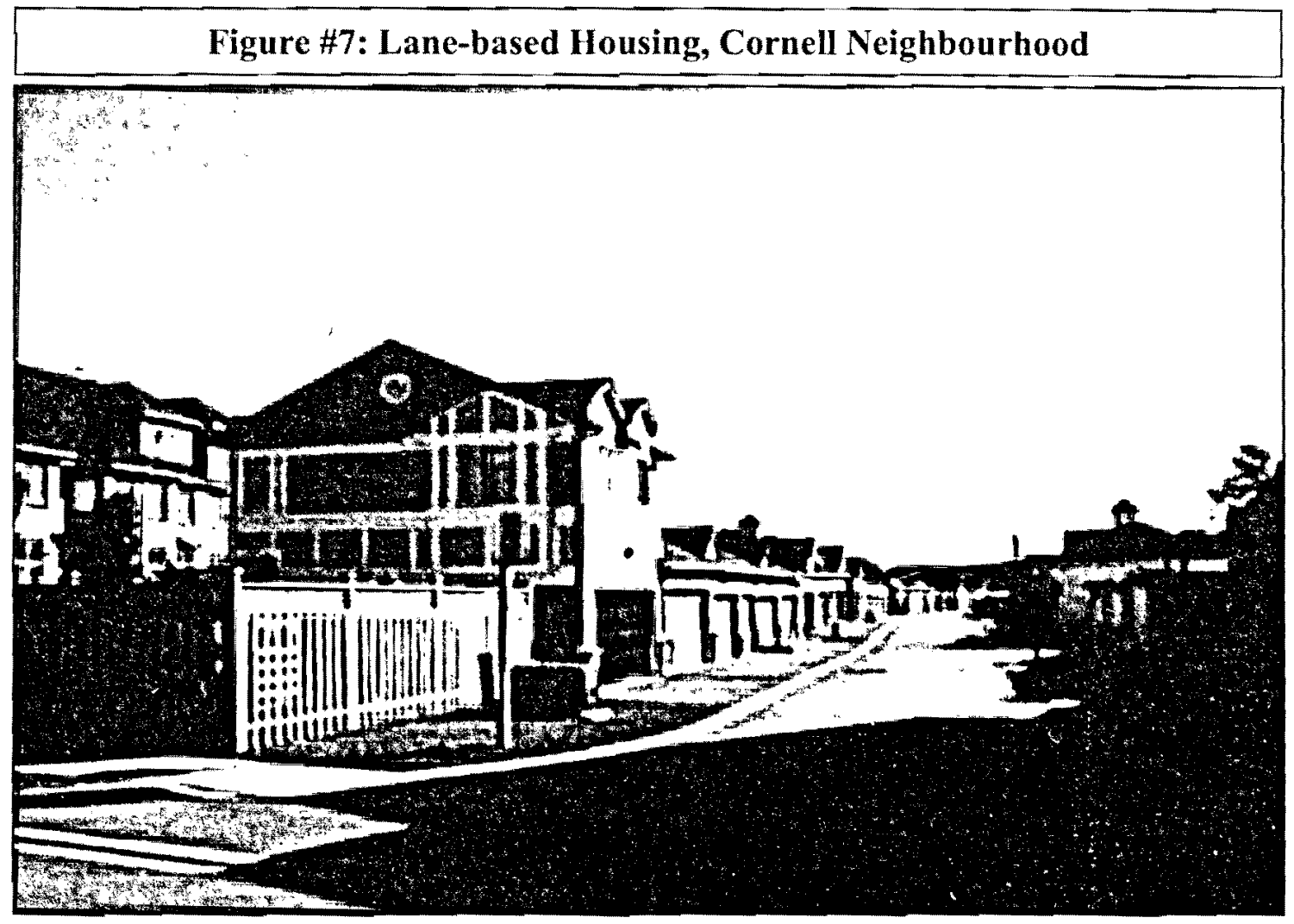

Source of image: Moore, 2010

also made affordability of housing an issue within the Town, as Grant (2009) outlines in her research with Markham planners. A recurring theme throughout most neighbourhood developments was the attempt in encouraging affordable housing, which was met with heavy resistance from local residents. Moreover, the issues of transit and funding have been constant barriers to each development's success. With the apparent lack of funding from senior levels of government for transit infrastructure, the new urbanist developments within Markham are still highly auto-dependant. However, this point may seem moot, given the fact that although some of the new urbanist neighbourhoods are transit-supportive, they are merely self-contained entities within a larger region ultimately reliant upon (obsessed with?) the automobile. Therefore, the new urbanist experience in Markham has brought to light four insights in regard to the research under review here. Frist, it is the convergence of the political will of Markham's bureaucrats to 
implement new urbanist development combined with market actors' hesitancy in applying new urbanist principles that has created most of Markham's new expansion over the last fifteen years. Secondly, while Markham champions itself as a new urbanist municipality, research suggests that many of the key elements which make a community "new urbanist" are ultimately missing from the newly planned communities. Instead, these new developments represent a hybrid of the conventional post-war suburb combined with selective aspects of new urbanism which caters to market forces. Thus, regardless of the prescriptive nature of zoning and land use which champions new urbanism, market forces combined with lack of political will have established developments uncannily familiar to post-war suburbia. Third, Grant's (2009) research suggesting residents' contestation toward affordable housing combined with the apparent agreement between developers and bureaucrats to not implement affordable housing within the newly built communities suggests systematic, new-build gentrification. Finally, regardless of its best intentions to promote new urbanism as Markham's new development paradigm, a competitive governance structure has constantly manifested new urbanism into something that is not. These converging points are placed at the crux of the argument for the Langstaff Gateway, yet have been ultimately perpetuated further by prescriptive planning legislation from higher levels of government, as the next section will briefly outline. 
Figure \#8: New Urbanist versus Conventional Neighbourhoods, Markham
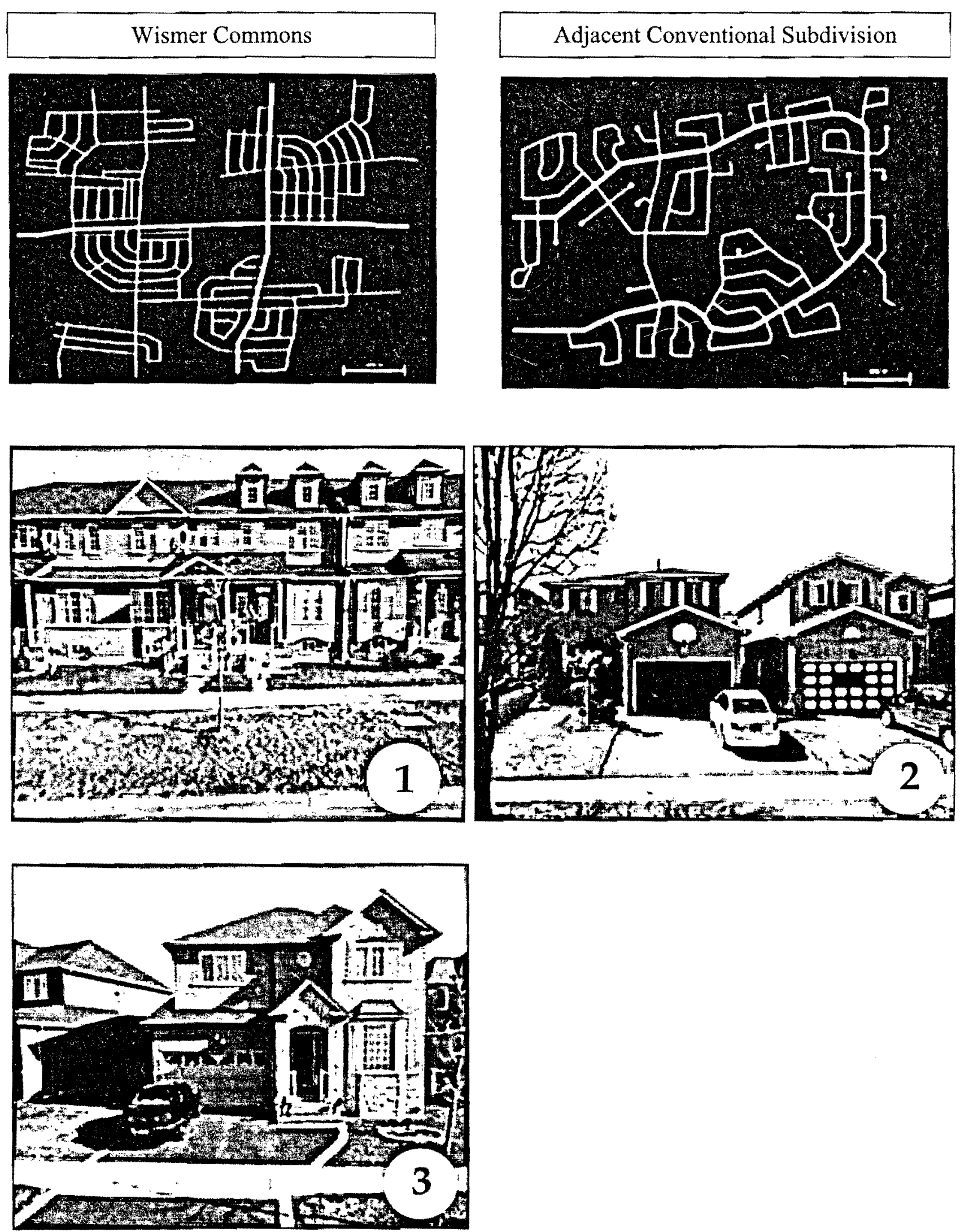

Source of maps and photos: Author 


\subsection{Planning the Greater Golden Horseshoe (GGH)}

Neoliberal urban restructuring intensified in Ontario beginning in 1995 under the provincial government of Mike Harris. Ultimately reminiscent of Thatcherism and Reaganism, the Harris government's Common Sense Revolution (CSR) was "a textbook case of a neoliberal policy strategy and project (which) arguably became one of the most interventionist governments the province has seen" (Keil, 2002, p.588). The amalgamation of Metropolitan Toronto ${ }^{9}$ amongst many other municipalities - was met with uncertainty and opposition most notably from middle-class urban dwellers who believed a bigger city would "dilute the power of downtown reformists against pro-growth suburbs" (Addie \& Fiedler, 2008, p 10). The effects of the CSR and amalgamation of Toronto are too myriad to introduce here (for a comprehensive list, see Keil, 2002, p.588-589) but official reasons include the reduction of elected officials (106 to 58), a streamlined improvement to efficiency, and the simultaneous realignment of provincialmunicipal responsibilities (City of Toronto, 2000). Although the effects of the CSR and amalgamation were generally met with apprehension and opposition, the same government enacted populist environmental protection policies during its second term, eventually leading to the re-appearance of regional planning within the GGH when a more interventionist government - the Liberal Party under Dalton McGuinty - took over provincial duties in $2003 .^{10}$ Indeed, as the Harris government was regarded as ostensibly neoliberal and anti-government, this was a surprising legacy (White, 2007).

In 2006, the Provincial Government ushered in a regional plan for the GGH with the creation of the Growth Plan for the Greater Golden Horseshoe (hereinafter the "Growth Plan"). The GGH is a rapidly growing metropolitan area with an expected population of 11.5 million and an additional 1.8 million new jobs by 2031 (Growth Plan, 2006). The Growth Plan promises to 
allocate this population through Smart Growth principles by intensifying downtowns, protecting farmland, curbing sprawl, and improving regional transportation within the GGH by 2031 (Growth Plan, 2006; White, 2007; see Table.2). The Growth Plan is legislated under the Places to Grow Act, 2005 and planned in conjunction with the Greenbelt Act, 2005, the corresponding Greenbelt Plan (2005), and Metrolinx's The Big Move regional transportation plan for the Greater Toronto and Hamilton Area (2008). ${ }^{11}$ Indeed, after many years of non-planning at the metropolitan level, the provincial government had once again entered into the playing field that is regional planning.

At the root of the Growth Plan is a policy framework which directs a minimum of 40 per cent intensification within the current "built up area" of municipalities within the GGH, combined with the delineation of 25 "urban growth centres" throughout the region (see Fig.1, Appendix B). ${ }^{12}$ The delegation and delineation of urban growth centres by the Province, in conjunction with upper-, lower-, and single-tier municipalities, are the focal points for intensification within each jurisdiction. Through various density targets (150 to 400 jobs and residents per hectare), the planning and design of urban growth centres act as "municipal downtowns" that:

- Attempt to attract a significant portion of population and employment growth;

- Act as focal points for investment in institutional and region-wide services, as well as commercial, recreational, cultural, and entertainment uses;

- Provide a diverse and compatible mix of land uses, including residential and employment uses to support vibrant neighbourhoods;

- Accommodate and support transit, walking, and cycling;

- Serve a high density of major employment centres that will attract provincially, nationally, or internationally significant employment uses; and

- Achieve higher densities than the surrounding area while creating an appropriate transition of built form to stable neighbourhoods (Growth Plan, 2006, s.s. 2.2.4).

Although seemingly prescriptive in nature, the Growth Plan does not aggressively implement any direct standards to urban growth centres, with the exception of some general 
guidelines (see Growth Plan, 2006, p. 16, 19, 32, \& 47). This is consciously executed, as the ideology behind the Growth Plan is to provide as much direction needed to municipalities without aggressive top-down intervention (White, 1007). Thus, the general principles, policies, and design of urban growth centres are implemented by local planning authorities, not by the provincial body.

Five of the 25 provincially-mandated urban growth centres are located within the City of Toronto proper, while the remaining 20 are located in municipalities traditionally regarded as suburban or exurban in nature. Two urban growth centres are located within the Town of Markham: Markham Centre and the Richmond Hill/Langstaff Gateway. Both urban growth centres are inspired by the principles of new urbanism - Markham Centre by Duany-PlaterZyberk and the Langstaff Gateway by Calthorpe and Associates. Furthermore, both urban growth centres represent the newest form of "demonstration project" for the Town of Markham. Yet, as discussed in the next chapter, the sheer magnitude of planned density, combined with the physical landform of the Langstaff Gateway site, creates an interesting case which encapsulates the forces of competitive governance, new urbanism, and new-build gentrification.

Table \#2: Growth Plan for the Greater Golden Horseshoe, Policy Backgrounder

- A minimum $40 \%$ of all residential development to occur within the built up area for upper- and single-tier municipalities by 2015

- The creation of 25 "urban growth centres" within the GGH, acting as focal areas for investment, intensification, and mixed land uses

- A framework for transportation, water, and community infrastructure through multiple investment strategies

- A balance approach to the use and management of natural resources including natural heritage, agriculture, and mincral aggregates Source: Growth Plan, 2006 


\section{Chapter 5: Markham's Latest New Urbanist Paradigm: The Langstaff Gateway}

\subsection{Site Analysis}

The Langstaff Gateway is a 47 hectare (116 acre) swath of land situated in the Town of Markham, representing approximately one half of the Richmond Hill/Langstaff Gateway Urban Growth Centre (MPIR, 2008). The site is situated between Yonge Street to the west, Bayview Avenue to the east, Highway 407/Richmond Hill Centre to the north and the Holy Cross Cemetery to the south (see Fig.9). At the time of writing this paper, a majority of the land consists of scattered small industrial and seemingly derelict residential lots. Initially developed as a residential neighbourhood in the 1920s, industrial uses began to evolve in an ad-hoc manner starting in the 1950 s, with initial land ownership characterized mostly by small, single-use owners who acquired the land for their own purposes (LDFS, 1995; LGMP, 2009). The use of land for industrial purposes includes concrete and stone products, automotive repair shops, open storage uses, landscape operations, and crane/heavy equipment storage (see Fig.10). Some of these uses are still in operation today.

The Langstaff Gateway is uniquely positioned at the convergence of three lower-tier municipalities within the Region of York: the Town of Markham, the City of Vaughan to the west and the Town of Richmond Hill to the north. From a planning and physical perspective, the site represents a nexus in which the three municipalities are linked; the Town of Markham and Richmond Hill share the boundaries of the Richmond Hill/Langstaff Gateway Urban Growth Centre, while a cooperative approach is required between all three municipalities to implement any form of regional transit system (see Section 5.3). The site itself, however, is largely disconnected from its municipal neighbours and adjacent neighbourhoods located in Markham. 


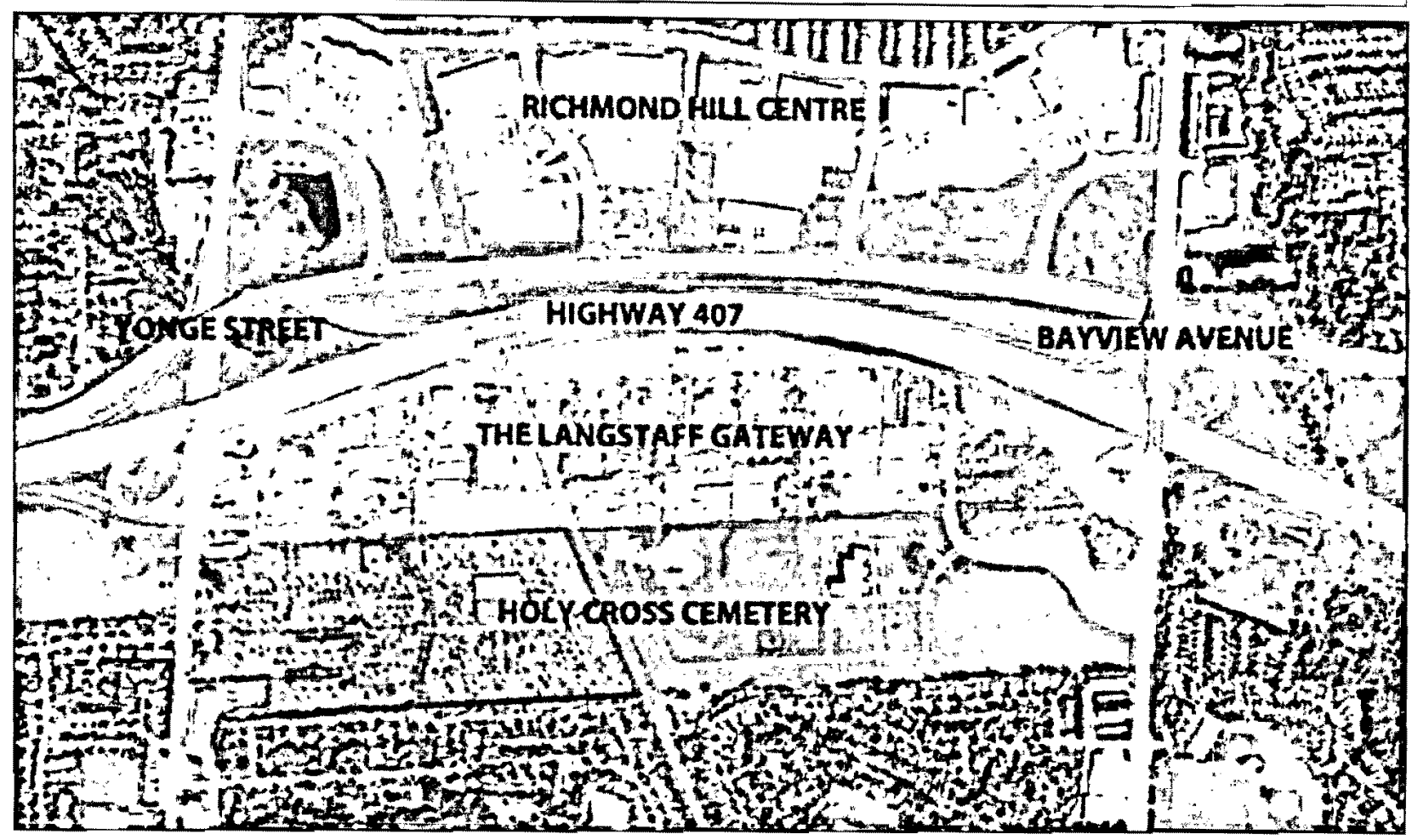

Source of background image: Digital Globe, 2011

A series of edges and barriers present a number of constraints for future development.

Although the western- and eastern-most parts of the site front onto the arterials of Yonge Street

and Bayview Avenue, on- and off-ramps to Highway 407 present connectivity barriers for future land use or transportation development. A large hydro transmission corridor also abuts the west side, further obstructing any connections to the Yonge Street arterial. Connections to the future Richmond Hill portion of the urban growth centre to the north is restricted due to Highway 407, Highway 7 (a regional arterial), and the above-mentioned hydro corridor. The 53 hectare (132 acre) Holy Cross Cemetery spans the southern border of the site, disconnecting it from the residential neighbourhood further to the south. Finally, a rail corridor owned by the Canadian National Railway (CNR) which also serves GO Transit operations bisects the site internally. If connections within the Langstaff Gateway are to be successful, grade-separated crossings must be employed. In addition, connectivity and accessibility constraints due to the above physical 
barriers pose the biggest challenge for the development of the Langstaff Gateway. It is important to also note that many of these barriers (i.e. the hydro corridor, railway, and Highway 407) require unique setback distances anywhere from 14 meters (Highway 407) to 30 meters (the CNR corridor) due to safety, noise, and vibration concerns (LGMP, 2009). Therefore, supplementary to the connectivity issues, future development must also respect the myriad of special setback provisions.

As mentioned above, current land uses within the Langstaff Gateway largely consist of small scale industrial and residential lots. Land uses within the general vicinity, however, are quite different than those on-site. Typical of outer suburb form and morphology, stable low density residential neighbourhoods (i.e. single detached dwelling) are directly adjacent to the east, west, and south sides of the site. Small-scale commercial uses are primarily present along Yonge Street, while the lands that encompass the Richmond Hill portion of the urban growth centre currently contain a large suburban-style (i.e. "big box") retail complex.

The Pomona Mills Creek, a tributary of the Don Watershed that encompasses 0.36 hectares ( 0.9 acres) of the Langstaff site, bisects the west end, while the 4.7 hectare (11.61 acre) Langstaff Woodlot encompasses the east (see Fig.11). Although low densities predominantly surround the site, the major barriers north and south of the Langstaff Gateway (i.e. Highway 407 and the cemetery, respectively) act as buffers which provide an opportunity to increase density levels and alternative built forms (i.e. multiple-storey residential housing). Therefore, the site presents an opportunity for intensified infill development without necessarily negatively impacting the stable residential communities adjacent to it. This development, however, must encompass a series of mixed uses, proper services, and adequate transit and transportation provisions. 
Due to the relatively stable land uses of the cemetery, the highway, and the low density housing, combined with the lack of connections adjacent to the site, vehicular traffic and circulation is extremely limited. The main east-west corridor through the site is Langstaff Road, which connects Yonge Street and Bayview Avenue, while north-south road connections are nonexistent due to the highway and cemetery. The current number of trips to the Langstaff Gateway via automobile per day is 10 , 000 , mostly due to the presence of the Langstaff GO Station, a regional train and bus station that connects to the Toronto core (LGMP, 2009). If development is to succeed on the site, it must successfully integrate with proposed and current transit systems, while providing additional transit amenity that is coordinated and userfriendly as population and employment increase.

Current transit providers serving the site include GO Transit, an inter-regional bus

\section{Figure \#11: Existing Land Uses Adjacent to Langstaff}

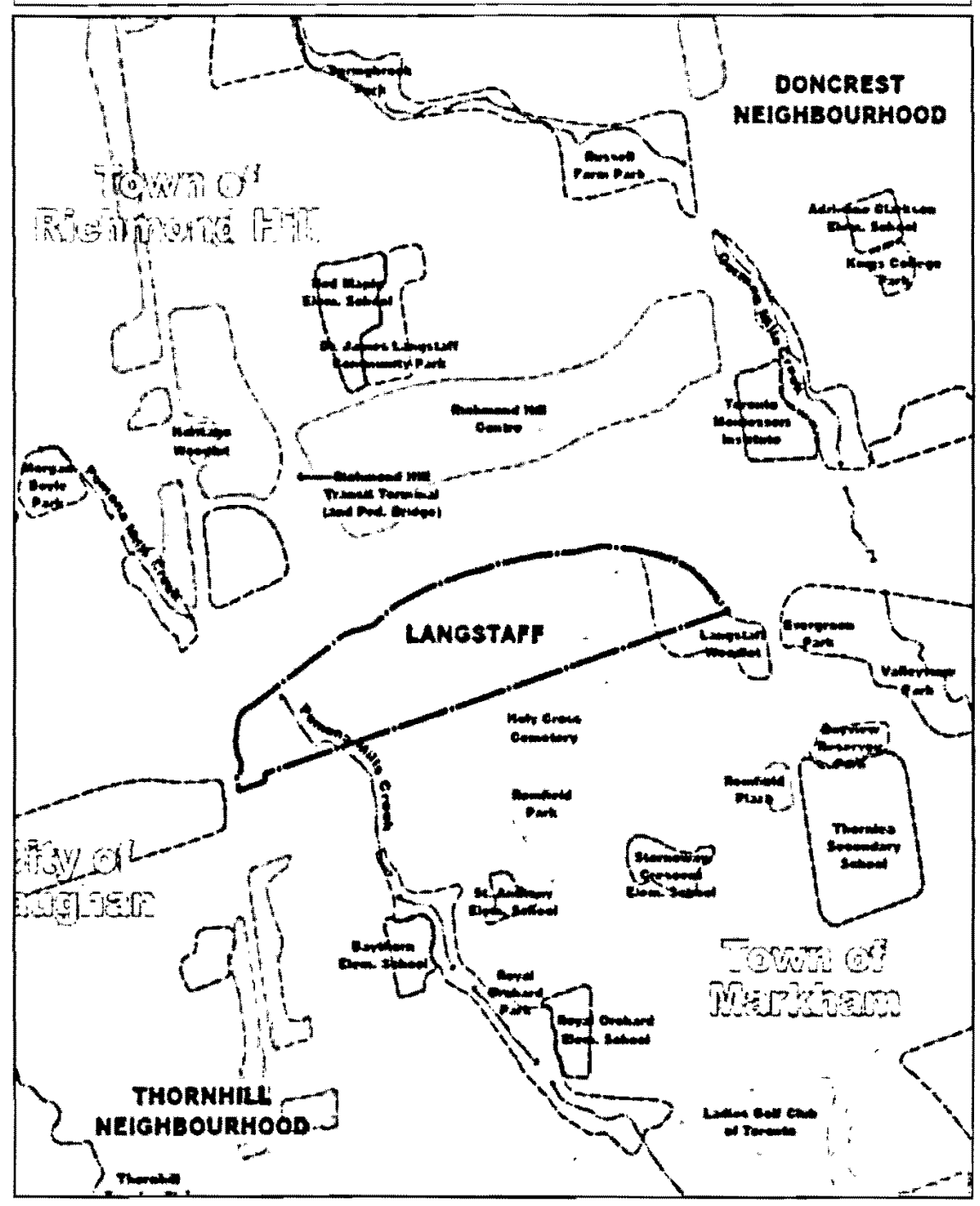

Low density residential housing (yellow) encompasses most of the area surrounding the Langstaff Gateway, while commercial land uses (red) are primarily located along Yonge Street and within the current Richmond Hill Centre in the form of retail and big-box style development. The Pamona Mills Creek bisects the west half of the site, while the Langstaff Woodlot is situated to the east (Source of image: LGMP, 2009) 
and train service run by the Province of Ontario, and Viva, a bus rapid transit system in the Region of York. Additionally, the Richmond Hill Centre Terminal is located north of the site within the Richmond Hill Urban Growth Centre; currently, a majority of this terminal is occupied by Viva service.

Due to the traditionally small scale uses within the Langstaff Gateway - current density is approximately 15 jobs and residents per hectare - water, wastewater, and stormwater servicing is limited to non-existent dependent on location. Current utilities within the site include regional and local water mains that parallel the existing roads and sanitary sewer lines located solely on the western end. Additionally, on-site stormwater servicing infrastructure is non-existent, with stormwater runoff currently following a southwest direction due to topography and slope (LGMP, 2009). Road-side ditches and culverts divert and convey captured stormwater to the Pomona Mills Creek and a pond located on the cemetery property. Future development would require the provision of an advanced servicing scheme due to minimal or non-existent sewer and water allocation.

Thus, the Langstaff Gateway is principally a self-contained entity given its stagnant physical barriers and adjacent land uses. The Town of Markham must continually be cognizant of such anomalies, particularly recognizing that redevelopment must institute a series of elements that are considered a necessary precondition for success: conventional suburban development (as outlined in section 4.3) will not suffice. Given these constructs, the following sections will outline the history, background, and planning process for the proposed redevelopment of the Langstaff Gateway. 


\subsection{History and Background}

The lands now known as the Langstaff Gateway were initially frozen for redevelopment due to provincial legislation under the Parkway Belt West Plan (1978) - an open space land reserve stretching from Markham to Hamilton delineated initially as an urban buffer and facility corridor, which worked in conjunction with the Toronto-Centered Region Plan (1970), the Greater Toronto Area's regional plan at the time. However, given the forecast of transportation changes abutting the site in 1986 , particularly that of the now built Highway 407 within the Parkway Belt, the Langstaff Gateway was regarded as an underutilized site with considerable development potential (LDFS, 1995). Official plan amendments initiated by the Town commenced in 1986 which designated the Langstaff site as part of the Town's urban boundary.

The amendment was approved in 1988 , the same time at which the site was incorporated into the newly drafted Thornhill Secondary Plan. Land uses within the Thornhill plan designated a majority of the properties for industrial uses, save for the cemetery to the south, the easterly woodlot (designated as an environmentally significant area) and a mix of low and medium density housing to the east. The Thornhill Secondary Plan also listed a number of constraints limiting development potential for the Langstaff site, with the most obvious being a lack of transportation capacity given the restricted number of road links and hard boundaries to the north and south (LDFS, 1995).

The first comprehensive redevelopment plan for the Langstaff Gateway outside of the Town-initiated Official Plan amendments occurred in 1995 under the Langstaff Development Feasibility and Urban Design Study. The recommended land use concept from the report suggested a new residential community to the east of the site, largely based upon the zoning and neighbourhood design principles of Cornell, while the west side consisted of a mix of retail 
warehouse and office uses to the west (LDFS, 1995, p.65; see Fig.1 - Appendix C). The report further outlined densities between 37 to 101 units per hectare and a maximum height of four storeys for the residential zone, with floor space indexes of 0.40 to 0.75 within the commercial zone. In addition, the report recommends that the Town of Markham pre-zone the land in order to provide additional incentive for land assembly and redevelopment, as well as to facilitate developers' interest. What is particularly important to note, however, is the realization of the obvious physical challenges of the site due to its structural boundaries. As the report states:

The strong boundary conditions (the highway interchanges to the north, west and east) as well as the cemetery to the south and woodlot to the east have created a unique condition that demands an approach to planning and urban design that allows for the development of an almost freestanding neighbourhood concept. What we have, in fact, is almost an island of development surrounded by these large buffering elements. The approach to planning and urban design must . capitalize on the unique conditions and not try to dissolve these realities. (LDFS, 1995, p.33)

Policies for the Langstaff site were updated in 1997 to reflect the findings from the Langstaff Development and Feasibility Report. However, these policies would never materialize due to changes in proposed infrastructure development and land use brought forth by the Growth Plan. The following sections will outline the provincial, regional, and municipal context in which the Langstaff Gateway is currently being planned.

\subsection{Current Planning Framework}

\subsubsection{Provincial Context}

The Langstaff Gateway is designated as an urban growth centre within the Growth Plan. Its total size - which includes the Richmond Hill component - is 175 hectares (432 acres) (see Fig.2, Appendix B). The Langstaff Gateway is centrally located within the Region of York, and is one of four urban growth centres earmarked by the Province for York Region. The Province 
anticipates that planned transit investments will generate future demand for intensification in the centre, and that "new development in the Langstaff Gateway portion of the urban growth centre presents opportunities for transit-oriented development" (MPIR, 2008, p.46). Indeed, the success of the site is largely reliant upon future transit proposals.

In order to further connect regional land use planning with the provision of transit, the Province created Metrolinx in 2006 (formerly known as the Greater Toronto Transportation Authority), a governmental organization intended to manage both long range transportation planning within the GGH and the Province's GO Transit system. The Big Move, Metrolinx's regional transportation plan, is a capital and investment strategy for transit that includes 15 and 25 year projections for transit allocation within the GGH. The Big Move works in tandem with the Growth Plan to allocate higher order transit connections with high-density urban growth centres such as the Langstaff Gateway within the GGH. This is through the delineation of "anchor mobility hubs" - intermodal terminals intended to coalesce local and regional transit with active modes of transportation (Metrolinx 2006, p.46; see Fig, 3, Appendix B). The Langstaff Gateway has been identified as an anchor mobility hub for its proximity to current and future local and regional transit operations. The most pressing issue for the development of the Langstaff Gateway, however, relies fundamentally on the extension of Toronto's Yonge Street subway system into the Region of York. The current subway system runs under Yonge Street from Toronto`s downtown core to Finch Station - a major transit node approximately two kilometres away from Markham's municipal borders. The planned six-station subway extension spans 6.8 kilometres north and ends at the Richmond Hill component of the urban growth centre (see Fig.12). Additionally, the subway extension is outlined as one of Metrolinx's top priorities within the first 15 years of the Regional Transportation Plan's implementation, with a proposed 
date of service beginning in 2017 (York Region, 2008). It is assumed that the appropriate form of higher order transit infrastructure is needed to create suburban communities that are transitoriented, mixed use, and sustainable.

Indeed, the subway extension is certainly a necessary precondition for the Langstaff Gateway; if the site is not in proximity to rapid transit, development on-site will not materialize into any substantial development vis-à-vis the Growth Plan. As a recent Viva (2008) report states, "less intensification within (the Langstaff Gateway) will probably mean more sprawl elsewhere in the Greater Toronto and Hamilton Area - perpetuating traffic gridlock" (p.4). In April 2009, the Ontario Ministry of Environment unconditionally approved the initial Environmental Assessment for the proposed extension. This was followed by the approval of conceptual designs and engineering elements later that year. The problem, however, boils down to funding; necessary funding from senior levels

Figure \#12: Proposed Yonge Subway Extension

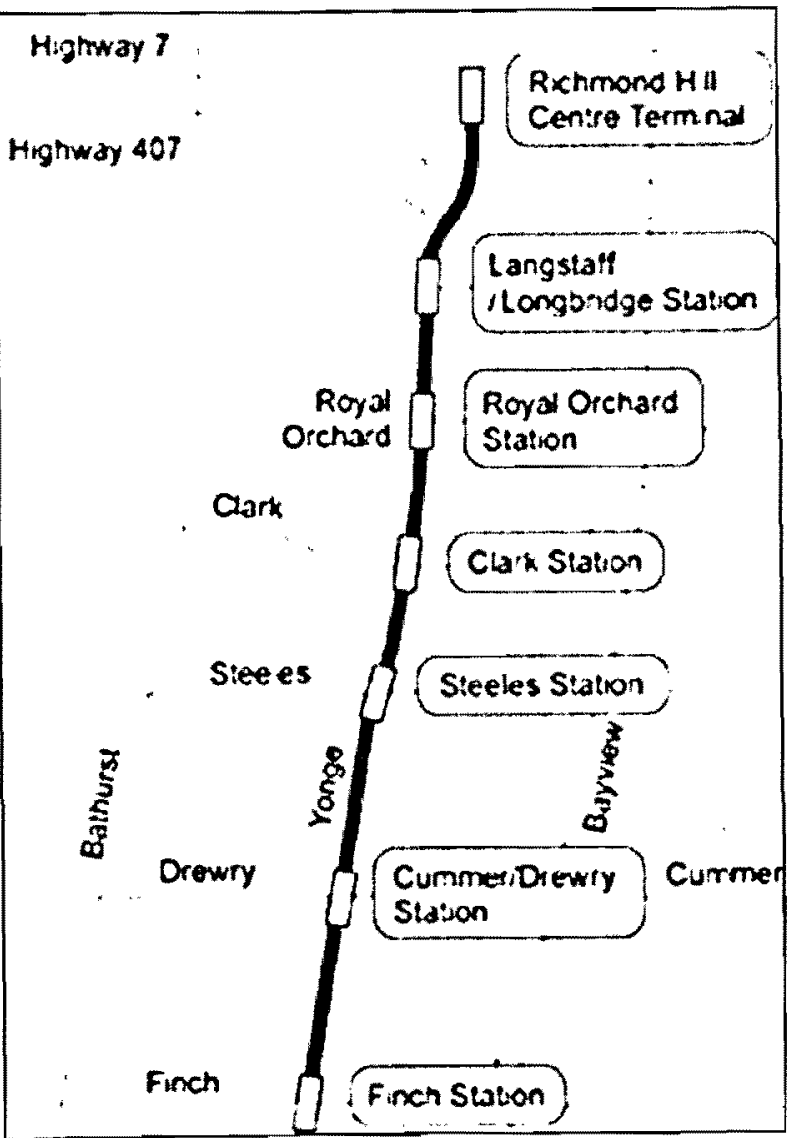

Source of image: Viva, 2008 of government (i.e. the Province) is required, given the expected capital cost of $\$ 2.4$ billion to build the subway (Metrolinx, 2009). Funding for this project has yet to be secured, with Metrolinx making a clear statement that they are not in a position to currently fund the work for the foreseeable future (Fleischer, 2009). Indeed, if the 
subway extension does not materialize, the built form and character of the Langstaff site will undoubtedly digress from its current vision.

\subsubsection{Regional Context}

The Region of York is the upper-tier planning authority for the Town of Markham. The Region's Official Plan designates the Langstaff Gateway as one of four "Regional Centres" located within the Region. Regional Centres are strategically located areas which act as regional hubs of business, government, and social activity (Region of York, 2010). The four Regional Centres are also designated urban growth centres within the Growth Plan, generally following the same policy framework (see Fig.4, Appendix B). Additionally, specific design and built form policies for Regional Centres follow a new urbanist perspective, as the Official Plan outlines Regional Centres as compact, welldesigned, transit supportive, and pedestrian friendly areas (p.54). It is also important to emphasize the importance of transit for Regional Centres; many of the Region's policies either allude to the delivery of public transit as a key driver for a Regional Centers' success (Sections 5.3.9(vi); 5.3.14) or outlines specific transit projects like the Yonge subway extension (Section 5.3.11) as necessary projects to support the implementation of Regional Centres like the Langstaff Gateway.

\subsubsection{Municipal Context}

Beginning in 2008, Town of Markham planning staff earmarked the Langstaff Gateway as one of the densest neighbourhoods within the GGH outside of the Toronto central business district, with an average density of 1,000 jobs and residents per hectare. 
Overall, the site is planned to accommodate 15,000 residential units (resulting in a population of 32,000), 340,000 $\mathrm{m}^{2}$ of commercial space, 10,000 jobs, and over 12 hectares ( 30 acres) of open/park space. The proposed density of 1,000 residents and jobs per hectare is four times higher than the Provincial mandate of 200 jobs and residents per hectare, and double the density of Toronto's central core (Fleischer, 2010; LGMP, 2009; MPIR, 2006).

The Langstaff Gateway site was officially legislated as an urban growth centre in 2005 , as Town planning staff began to explore new development opportunities with a cognizance toward the obvious physical boundaries of the site. The policies outlined within the 1997 Thornhill Secondary Plan were deemed unfit for redevelopment (Town of Markham, 2008). Thus, a technical Official Plan amendment was drafted in 2008 to delete the Langstaff Gateway site from the Thornhill Secondary Plan and re-designate it into the "Langstaff Urban Growth Centre Study Area" (Town of Markham, 2008, p.11). In doing so, the technical amendment outlines that the Langstaff Gateway "will provide some of the highest densities in York Region to support the transit and transportation hub" (Town of Markham, 2008, p.12). The technical amendment also outlines the need for a comprehensive community master plan that incorporates policies from the Growth Plan and The Big Move. This plan came to fruition in 2009 through the Langstaff Gateway Land Use and Built Form Master Plan (2009) designed largely under new urbanist proponent Peter Calthorpe. A subsequent Secondary Plan which lends heavy credence to the Master Plan was approved by the Town's Council in 2010. The following sections will outline the major components of the Master Plan and Secondary Plan. 


\subsubsection{1: Design and Land Use Framework - The Langstaff Gateway Land Use and Built}

Form Master Plan

The Calthorpe-inspired Master Plan largely utilizes the ideology of new urbanism through four design principles: diversity and balance; conservation and restoration; human and pedestrian scale; and connection and interdependence (p.22). The principle of diversity and balance establishes a vision for the Langstaff Gateway to be an inclusive and mixed-use community. This is through a mix of civic, commercial, and residential land use combined with variable housing units that meet the needs of seniors as well as students. Indeed, at the crux of diversity and balance is new urbanism's primary notion of a complete community through various land uses, housing types, and housing tenures. As previous case studies in Markham have shown, this is no easy challenge; although a harmonious balance of the above components may indeed determine and strengthen the neighbourhood's character (as the Master Plan suggests; see p.23), achieving this harmony while satisfying market forces is a key challenge, particularly within a municipality that consists of mostly single-detached dwellings isolated from other land uses.

Conservation and restoration pays homage to the current natural and historic features of the Langstaff site. Key natural features located on-site include the Pomona Mills Creek to the west and large woodlot to the east. A total of seven structures have been designated heritage sites, with a majority situated just west of the railroad tracks. The Master Plan envisions the adaptive reuse of the heritage sites while concurrently maintaining its historical relevance (p.15). Key natural sites follow the traditional principles of preservation and restoration, thereby reinforcing the axiom of nature versus culture (p.23). The intent to preserve and restore is a respectable principle to follow, yet 
to truly sustain the natural environment in which development will encroach, the conflation of ecology and infrastructure with a de-emphasis on simply preserving is perhaps a more sustainable approach (see Waldheim, 2006). Enhancing and naturalizing the environmental landscapes of the Langstaff Gateway may prove costly in the short term, but ultimately provides limited long term operation and maintenance, thereby becoming adaptable to environmental uncertainty and complexity (see Lister, 2007).

The third principle of planning for the human and pedestrian scale represents the key focal point for the site (p.24). Given the obvious physical barriers outlined above, the main driver for success relies upon creating an interdependent pedestrian-scaled environment, while achieving a level of municipal and regional connectivity via public transit and limited automobile access. According to the Master Plan, walking will be ideal through a number of design-related goals: building facades will be scaled appropriately for the human environment; inter-modal transit will be provided to increase human mobility; traffic calming devices will be utilized to slow down the automobile; parking lots will be buried underground or stacked above grade via a parking structure; mixed use development will increase the pedestrian shopping experience through atgrade retail along the major "spine" of the site; and key destinations will be located within a five-minute walk of transit. Indeed, the focus is seemingly always on the pedestrian.

Finally, the principle of connection and interdependence is an obvious indicator of the complexities related to the site. Cognizant that the Langstaff Gateway is a selfcontained entity, the Master Plan outlines the importance of making regional, district, and neighbourhood connections, both physically and socially. This layered understanding of 
the area is supplemented with a mandate to conceive land use elements of the Langstaff Gateway as one unit; every piece of the neighbourhood element (i.e. housing, shops, open space, civic institutions, and businesses) must be present within the Langstaff Gateway in order for it to succeed. Thus, unlike many past new urbanist neighbourhoods built in Markham, the residential uses within the Langstaff site must be supplemented with appropriate commercial amenities, employment opportunities, and civic institutions.

At the crux of built form policies is the inherently new urbanist ideology of residential blocks, transit nodes, and retail/employment centres (p.34). This hierarchical order through blocks, nodes, and centres is predominant throughout the entire plan, as a majority of planned blocks measure $70 \times 85$ metres and incorporate residential housing between 4-storey low rise apartments and 50-storey point towers (see fig.13). Ground floor retail and non-residential uses are a requirement along the site's main east-west arterial. Employment uses abut the northern boundary to buffer the noise and vibration of Highway 407. The stagnant physical barriers outlined above are still very much an issue; the proposed neighbourhood is largely a self-contained entity - indeed, an "island of development". Therefore, connectivity, accessibility, and the provision of social and civic services are key characteristics to the overall success of the site. Furthermore, the obvious barriers present an opportunity to attain such planned densities. Although a relatively large amount of land use surrounding the Langstaff Gateway is single-detached residential, the neighbourhoods are set back far enough for the Langstaff Gateway to accommodate mid- and high-rise housing (see Fig.2 - Appendix C).

The Master Plan relies heavily upon the extended subway system for the overall plan and vision to be implemented. Designed over three phases, the Master Plan outlines 
various development benchmarks, which are internal and external to the site, before each subsequent phase can begin to be developed. With the exception of phase one, each subsequent phase requires the proposed Langstaff Gateway Subway Station to be operational before development can begin (see Fig.3, Appendix C).

\subsubsection{2: Municipal Policy Framework - The Langstaff Gateway Secondary Plan}

The Langstaff Gateway Secondary Plan (2010) supplements the Master Plan through a regulatory framework of municipal planning policy. The policies outlined within the Secondary Plan are also consistent with the intensification policies of the Growth Plan and transportation policies of The Big Move. In keeping with the notion of Markham as "Canada's Centre of Excellence for New Urbanism", the new urbanist principles found within the Master Plan are re-established within the Secondary Plan, combined with supplementary objectives that lend credence to sustainable development, the natural environment, mixed land uses, transit-supportiveness, and the public realm (pp.13-15). Established land use designations are parallel to the development and design concepts of the Master Plan; the majority of land use within the Langstaff Gateway is designated residential, while the main east-west corridor is designated for mixed use. Office uses are maintained as a buffer between the highway and residential uses (see Fig.4, Appendix C).

The Secondary Plan establishes residential neighbourhoods as the fundamental structural elements of the Langstaff Gateway, offering housing options to allow for a diverse mix of household sizes, lifestyles, and incomes (p.18). Additionally, the 
provision of affordable housing is mandated by allocating 35 per cent of all units to be "affordable"; a term that has yet to be defined by the Secondary Plan (p.4).

The development contemplated by the Secondary Plan is expected to mature past 2031 (the year current Growth Plan targets end), with benchmarks and triggers parallel to the Master Plan. What is important to note, however, is the lack of pre-zoning provisions for the site. While the 1997 feasibility study encouraged the use of pre-zoning, the current Secondary Plan implies that an amendment into the Town's urban expansion bylaw be established to implement the policies and provisions outlined (p.85).

The provision of transit is also considered an essential element to the Secondary Plan. To prioritize transit, the utilization of transit oriented development is employed to shape the built form and character of the proposed neighbourhood (p.16). Retail, highrise residential, and offices are largely focused around the west (the proposed Langstaff Subway station) and east (the existing GO Transit station) transit nodes of the site. These areas are serviced by an internal transit circulation system through the establishment of a "transit spine" along the linear park system that links the east and west nodes (see Fig.5, Appendix C). Furthermore, transit-dependent development is promoted and implemented through a series of implementation benchmarks and design features: the assurance that all parts of development are within a 5-10 minute walking distance to public transit; the provision of transit waiting areas in major buildings adjacent to transit stops; on-site parking positioned away from the front of buildings; and the establishment of pedestrian walkways and waiting areas that are attractive and weather protected (p.57). Emphasis is also placed on active transportation with the establishment of a comprehensive pedestrian and bicycle path system (p.61). 
Lastly, the Secondary Plan relies upon the use of architectural determinism to implement the major principles and policies outlined. A range of building densities (through floor space index measures) and heights (through maximum and minimum storeys) provide firm guidelines to ensure the desirable urban form outlined within the Master Plan. Floor space index is at its highest on the east (CNR) and west (Langstaff Gateway Subway Station) transit nodes. FSIs range from 10.1 to 15.9 on the east node and 10.2 to 15.5 on the west node. In addition, all buildings within the Langstaff Gateway are to have a minimum of three storeys (p.52), with the highest storeys (15-50) secluded to proposed point towers surrounding each transit node, and the employment district abutting Highway 407 (see Fig.6-7, Appendix C). Emphasis is placed upon the pedestrian through at-grade retail along the spine of the Langstaff Gateway. The Secondary Plan also provides policies for weather protected pedestrian walkways, arcades, and landscaped courtyards to promote walkability during all seasons (p.51). 
Figure \#13: Langstaff Gateway Land Use, Massing, and Proposed Housing Types
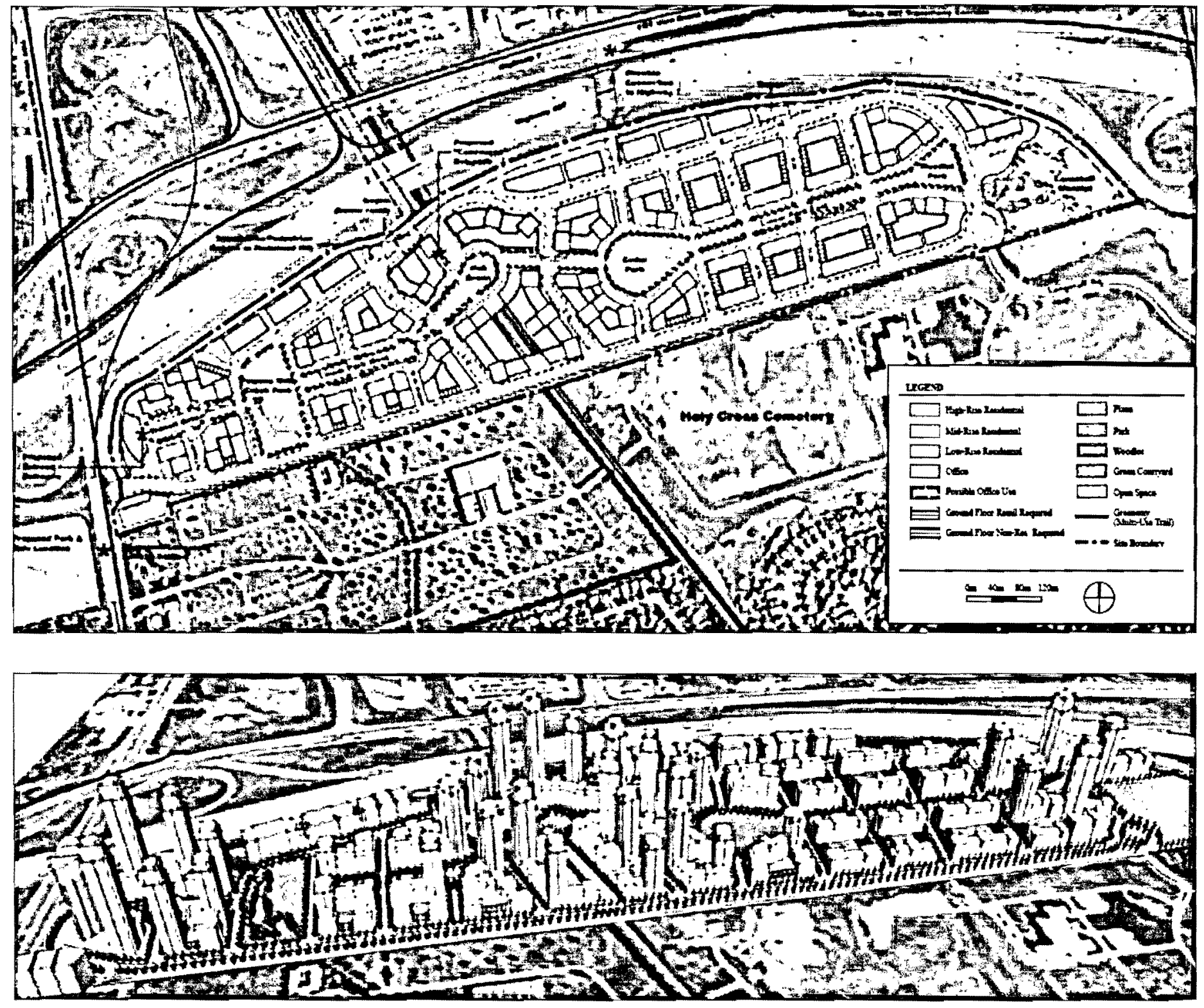

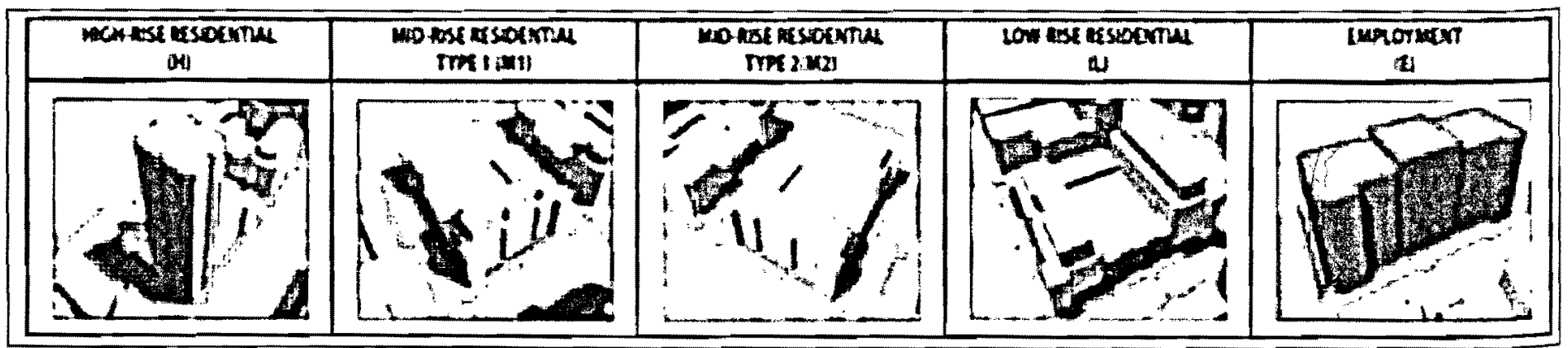

Source of images: LGMP, 2009 


\section{Chapter 6: Analysis and Recommendations}

\subsection{Analysis}

Given what is known about the policies and provisions regarding the Langstaff Gateway, the following section will analyze the three major constructs outlined throughout this paper as it relates to the site. Specifically, this section will address if the site represents the culmination of neoliberal and competitive governance forces at work, if it is reflective of a contemporary new urbanist design that will set a precedent for the GGH, and if it perpetuates the forces of newbuild gentrification.

\subsubsection{Competitive Governance}

The Langstaff Gateway has been planned under a multitude of political and economic forces. At its broadest and most regional level, the site has been earmarked as an urban growth centre in order to facilitate population increases through infill development. At its local level, it is representative of a competitive municipal government willing to implement new design and development trends that have yet to be tested on the ground. This has materialized into regional (the York Official Plan) and municipal (The Langstaff Gateway Secondary Plan) policy that has followed the new urbanist mantra of complete communities, mixed use, and density, as encouraged in the Calthorope-inspired Master Plan. Concomitantly, while senior levels of government has stepped back into the regulatory role of metropolitan planning - quite possibly the antithesis of neoliberal ideology - they also lend credence to market forces that perpetuate the political, economic, and cultural complexities inherent with North American suburban development. The delineation of urban growth centres spread across the GGH maintains the notion of local municipalities competing for capital accumulation; the end result is development 
of neighbourhoods which set precedents in design, development, and density. Indeed, the development of the Langstaff Gateway certainly reflects this consequence.

This report posits that current planning legislation and policy within the GGH represents a new scaled-hybridity of neoliberalism similar to the Australian case studies outlined above. It does not fully reflect the urban development projects as outlined in Swyngedouw et al's (2002) research and certainly does not revert back to the Keynesian-welfare ideology. Instead, it represents a contextually specific expression of actually existing neoliberalism constructed by both state and market interaction. The regulatory framework of the Growth Plan represents topdown principles and guidelines to ensure the appropriate amount of residential and employment development within each municipality. These guidelines however, are ultimately dependent upon the local municipality to materialize. Thus, the key driving force will rest in the hands of local bureaucrats who will control what the Langstaff Gateway will develop into. Yet somewhat paradoxically, despite this ostensible local power, the success of the Langstaff Gateway relies fundamentally on the commitment of senior levels of government to fund the extension of the Yonge Subway: if the proposed densities of the Langstaff Gateway are to occur, higher order transit must first be constructed. Therefore, the Langstaff Gateway represents a scaled neoliberalism (McGuirk, 1997) which is dependent on the unique interactions between the various levels of state and private sector involvement. The local is vitally important, but it is contextualized and empowered by scaled neoliberal policy tendencies. Thus, the new urbanist initiatives championed by the Town of Markham are resigned to the fact that the success or failure of the Master and Secondary Plan rests upon the operation and negotiations of state agencies (i.e. Metrolinx to provide funding) and their budget constraints and priorities. It is essential, then, to bridge this scaled disjuncture by working collaboratively with all levels of 
government. The relationship between various levels of government indeed has profound impacts on social and economic issues at the local level. Effectively addressing major local matters often requires the coordination and cooperation of multiple levels of government. The establishment of such coordination is essential for the Langstaff Gateway to succeed.

\subsubsection{Contemporary New Urbanism}

In many ways, the Langstaff Gateway represents one part in a series of successive new urbanist demonstration projects located in Markham. The design fundamentals of the Langstaff Gateway are inherently urban in nature yet aimed to succeed within a suburban locale. Unlike past new urbanist projects built upon swaths of open greenfields, the Langstaff Gateway is resigned to its unique physical barriers while boasting a density and built form unprecedented within the GGH. This has perpetuated neither a contemporary style of development that represents traditional suburban new urbanist developments (e.g. Markham) nor new urbanism's seemingly natural extension of built form when implemented in urban areas (e.g. the Toronto Beach Neighbourhood; see Moore, 2010).

Although this has as much to do with the sheer ambiguity of new urbanism, the demonstration project that is the Langstaff Gateway produces a new benchmark for suburban infill development across the GGH. The site is inherently unique due to its location and physical barriers - a definite anomaly in the GGH - yet its design and development principles will undoubtedly be transferred to other suburban-based infill areas within the region, particularly given current provincial planning framework. The self-contained nature of the site provides exceptionally large setbacks to any adjoining neighbourhoods, allowing the proposed height, massing, and density to occur within the Langstaff Gateway without having significant negative 
physical ramifications. In addition, the proposed subway extension is attributable as a necessary precondition for such densities and heights to materialize. Given these factors, the Langstaff Gateway represents a key opportunity to make use of underutilized land, yet simultaneously establishes a precedent that may only succeed in areas with similar physical characteristics and political-economic frameworks.

Therefore, the ramifications of this paradigm are progressive yet ominous. The Langstaff Gateway represents a perfect storm of elements: a municipality willing to implement new design and development fundamentals to remain competitive; a site constrained by stagnant physical barriers; reformed provincial planning policy that promotes suburban intensification; and a development market cognizant of the need to diversity traditional new urbanist design fundamentals. Much like its formulaic characteristic of Cornell, the Town of Markham has established a new formula under contemporary planning legislation that maintains a uniqueness and price premium within the local marketplace. If developed and implemented correctly, the Langstaff Gateway has the chance to become a successful mixed-use community; in its own right, this is a positive outcome. Yet, if market actors are hesitant to fully embrace this design schema when applied to other areas of the GGH (due to a myriad of social, economic, and physical factors), the region will continue to witness fragmented new urbanist communities similar to Markham's post-Cornell neighbourhoods (i.e. the continued perpetuation of sprawl). Furthermore, if developers continue to cherry-pick housing types and designs appropriate to the wider market in order to reduce economic risk, the current state of unsustainable, autodependent, and class-homogenous development within the suburbs will undoubtedly continue. Thus, it is imperative moving forward to remain cognizant that the development principles of the Langstaff Gateway represents a contemporary paradigm in new urbanist planning, yet also an 
anomaly that may only succeed on the given site, or sites that are inherently analogous to it.

\subsubsection{New-Build Gentrification}

Given that the Langstaff Gateway has yet to be developed, it is difficult to gauge the possibility of direct or indirect displacement by new-build gentrification. However, certain factors may suggest new-build gentrification is indeed a pre-determined policy tool. Although current land use policy in both the Master Plan and Secondary Plan for the Langstaff Gateway allocate affordable housing targets of 35 percent on-site, there is a very real possibility that this may never materialize. As recent literature suggests, a series of neoliberal phenomena - through public private partnerships (Hanlan, 2008), suburban revanchism (Niedt, 2006), or the coupling of new urbanism and pro-gentrification policy via competitive governance (Davidson \& Lees, 2010; Hanlan, 2008) - may indeed manifest the Langstaff Gateway into an elitist neighbourhood, thereby indirectly displacing residents looking for affordable housing. Additionally, the Langstaff Gateway is reflective of Davidson's (2007) four principles of new-build gentrification stated above: the Langstaff Gateway development upgrades the social composition of the neighbourhood, results in a significant landscape change, involves a significant reinvestment of capital into previously devalorised space, and generates processes of replacement and displacement.

Subsequently, it is simply myopic to believe that Markham's relative affluence (the Town's average household income is well over $\$ 100,000$ per year; see Town of Markham, 2010a) should have an influence on where (and even worse, if) affordable housing should be placed within new communities (see Grant, 2005). The allocation of affordable housing is certainly needed; many residents in Markham earn less than $\$ 30,000$ per year and are in need of 
affordable housing. Moreover, the GGH as a region is continually plagued by affordable housing waiting lists lasting $12-15$ years, with over 70,000 applicants in the neighbouring City of Toronto alone (Toronto Board of Trade, 2010). Indeed, continued NIMBYism ("Not in My Back Yard") against affordable housing has traditionally been an issue in the Town, as planners repeatedly struggle with resistance from local residents in regard to the allocation of affordable housing (Grant, 2009). Therefore, the seemingly unassuming regulation of 35 per cent affordable housing certainly has the potential to be trumped by competitive development policies and resistance from local residents. This is combined with the fact that the Town has yet to fully establish a Town-wide affordable housing strategy (Town of Markham, 2010b). Appropriate measures can be made, however, to ensure the 35 per cent policy is implemented (see below), but it will require the political will from current bureaucratic actors as well as the realization by local constituents that affordable housing is not analogous to the ghettoization of existing neighbourhoods.

\subsection{Recommendations}

Given the above arguments, it is clear that the three constructs outlined throughout this paper are inherently tied in some form to the Langstaff Gateway development. Indeed, a plethora of physical and social implications, combined with the political-economic forces of competitive governance, have created a series of challenges and issues for planning the site. Thus, a series of recommendations for the Langstaff Gateway are outlined above. It must be noted, however, that although these recommendations are inherently tied to the Langstaff Gateway, they are also attributable to other suburban municipalities located within the GGH. 


\section{Pre-Zone the Site}

Zoning has largely been utilized as a regulatory tool for municipalities in regard to setbacks, height, densities, and permitted uses. Given the scope and importance of the Langstaff Gateway as a demonstration project that may very well significantly influence the rest of the $\mathrm{GGH}$, it is important for development to follow the goals and provisions outlined during the master planning process. Therefore, it is imperative for the Town to pre-zone the property in order to fulfill the necessary land use and social objectives needed for this development to succeed, particularly given its many physical barriers. Past development paradigms within the Town have witnessed the trend of succumbing to market forces through fragmented urban forms of new urbanism, with designs fit to meet the needs of the market. Pre-zoning land will ensure that appropriate land uses are implemented - specifically employment and institutional uses that have traditionally lacked within Markham's current new urbanist communities.

Pre-zoning provides a positive environment and incentive to the development and public by removing any uncertainties related to development. Developers will be able to design and build projects within the Langstaff Gateway in a straightforward and profitable manner while mitigating the inherent risks associated with traditional infill development projects (i.e. rezoning of land). Developers working within this regulatory framework will know how much they can build and the general timeframes for approvals. By forgoing the rezoning process, developers will experience a significantly reduced approval time frame if development is built within the asof-right permissions.

Current policy within the Langstaff Gateway Secondary Plan is to amend properties onsite into the Town's urban expansion by-law once development is proposed ( $\mathrm{p} .85)$. The amendments, as the Secondary Plan states "shall incorporate, where appropriate, elements of the 
Langstaff Gateway Land Use and Built Form Master Plan" (p.86, emphasis added). Given the track record of the Town of Markham manifesting the policies of new urbanism to fit a competitive agenda - combined with Provincial planning policy perpetuating capital accumulation through intensification - the assurance of a true mixed-use community rests on preordained zoning ordinances - as applicable law - through a comprehensively planned zoning by-law explicitly for the Langstaff community. In doing so the site will: manifest into a true mixed-use neighbourhood; maintain a built form fabric championed by developers, politicians, and local citizens; firmly provide the necessary benchmarks for appropriate phasing; and provide transparency to the development industry and public at large.

If a comprehensive pre-zoning model is not an option due to various bureaucratic or market forces, the utilization of contemporary planning tools supported by the Provincial government - such as the Development Permit System (DPS) - is perhaps the next best option. Utilizing the DPS would provide a more piecemeal approach to developing the Langstaff Gateway than the use of comprehensive as-of-right zoning. The DPS streamlines development by combining zoning, site plan, and (if necessary) minor variance processes into one application and approval process (MMAH, 2007). The DPS also permits municipalities to identify discretionary uses without a by-law amendment, flexible development standards, and the implementation of various conditions to approval. Although ostensibly a progressive development tool that allows flexibility for design and development, the DPS is clearly a second best option for the physical site and the political-economic environment in which it is being developed. The DPS ultimately has the potential of being steered to further perpetuate the status quo that is Markham suburbia. Therefore, the most appropriate measure to ensure proper land uses and densities is to pre-zone the site through a comprehensively planned by-law. 


\section{Implement Affordable Housing Targets Through Inclusionary Housing Tools}

Given recent literature on the ramifications of new-build gentrification, the assurance of affordable housing within the Langstaff Gateway is a key aspect to provide a range of affordable housing options for residents of all ages, incomes, and walks of life. As stated above, although the Town of Markham is a relatively affluent community with average yearly incomes of $\$ 130,000$, households in greatest need (i.e. the lowest 30 per cent of income distribution) are earning less than $\$ 23,000$ a year and can only afford $\$ 586$ per month on rent (Town of Markham, 2010b, p.5). While the Region of York requires a minimum of 35 per cent of housing to be affordable within the Langstaff Gateway (LGSP, 2010), the Town of Markham Official Plan presently does not have an affordable housing target or strategy.

According to the Town (2010b), the affordable rental threshold is $\$ 1,008$ per month for household incomes of approximately $\$ 39,880$, while the affordable ownership threshold is $\$ 2,568$ for household incomes of $\$ 103,453$. Based on these statistics, rental housing is considered affordable to households earning less than $\$ 39,880$, and ownership housing is considered affordable to households earning less than $\$ 103,453$. Unfortunately, Markham's current housing stock does not meet this demand for affordable rental and ownership, as over 15,000 households in Markham earn less than $\$ 39,880$. With the exception of small private rental units (i.e. one bedroom apartments), these households rely upon social, emergency, and supportive housing.

Given these factors, the following five recommendations to implement affordable housing within the Langstaff Gateway are as follows:

i. Use inclusionary zoning to meet the 35 per cent target: the use of inclusionary zoning is an influential tool that requires and encourages private developers to construct some portion of new residential development for affordable housing. In exchange, the Town 
gives cost offsets to the developer through density bonusing (which runs parallel to the Langstaff Gateway's density targets and design solutions);

ii. Encourage a mix of housing type and tenure within the Langstaff Gateway that will meet the needs of seniors, youth, and families, particularly in regard to ground-related dwellings on-site (i.e. low rise apartments and stacked townhouses), and examine the feasibility of lowering development charges for these dwellings to provide incentives to developers;

iii. Defer development charges and parkland dedication fees in exchange for the development of affordable ownership and rental housing. Deferment of these fees would remain in effect providing the property remains affordable;

iv. Address NIMBYism by local residents through healthy dialogue, negotiation, appreciative inquiry, and relationship building. It is also important, however, to outline the need for affordable housing in the Town and GGH as a whole; and

v. Provide housing choice vouchers: given the argument that the Langstaff Gateway may represent systematic gentrification, the use of housing choice vouchers to provide affordability to those who cannot afford market-based units is an alternative option. Utilized widely in the United States, housing choice vouchers give the opportunity to assist low income households to afford market-based housing. The participant is free to choose any housing that meets the requirements of the program and is not limited to units located in subsidized housing projects. A housing subsidy is paid to the landlord directly by the authorizing public housing agency (in Markham's case, the Region of York). The family then pays the difference between the actual rent charged by the landlord and the amount subsidized by the program (see HUD, 2011). Implementing this system would require all levels of government to cooperate, but would also provide an alternative option to integrate lower income households into market-based units, as opposed to building separate market-based and affordable units.

\section{Collaboratively Implement and Fund Transit Infrastructure}

The provision of transit infrastructure is the key element for the Langstaff Gateway to succeed. Given the site's proposed development densities and physical barriers, auto-oriented sprawl will not be a viable option for the site. Lack of north-south connections guarantees a reliance on the proposed east-west arterial to the south of the site, thus becoming the main connector between Yonge Street and Bayview Avenue. Given these circumstances, the allocation of 1,000 jobs and residents per hectare through auto-oriented development will look 
much different than the same target through transit-oriented development. Recent new urbanist developments within Markham such as Wismer Commons have had the luxury of zero physical barriers, utilizing $2 \mathrm{~km}$ by $2 \mathrm{~km}$ concession lots as a test site for new development trends (this includes the communities of Greensborough, Berczy Village, and Cathedraltown).

Unfortunately the outcome has been less than inspiring; major arterial roads surround the site in all directions, perpetuating an auto-oriented culture that flocks (via automobile) to the Town's arterials which, as expected, are already at overcapacity. Yet again, the mantra has been simple: submit to market forces and developers will build (see Grant, 2009).

The Langstaff Gateway does not have this luxury. It sits at the convergence of three municipalities, abuts a major urban corridor, and possesses a very specific boundary. Therefore, the implementation of inter- and intra-model transit is the basis in which the Langstaff site will succeed. Every level of government - provincial, regional, and municipal - has earmarked the Langstaff Gateway as a mobility hub in one form or another. The site is established as a convergence zone between local and regional transit combined with active modes of transportation. Simply stated, given the densities and physical barriers, the proposed development relies on the subway extension as a necessary precondition - a bus rapid transit system will not suffice. The proposed subway extension to the Richmond Hill/Langstaff Gateway will ostensibly facilitate increased densities while providing superior environmental, economic, and land development impacts (Metrolinx, 2009). This is undoubtedly the underlying ideology present in both the Langstaff Gateway Master Plan and Secondary Plan, as development phasing for the site is concisely attributed to the proposed subway extension (see LGMP, 2009, pp.171-180; LGSP, 2010, pp.81-85).

Yet, the growth factors due to the proposed subway extension possess a multitude of 
spillovers outside of the Langstaff Gateway. The additional ridership projected from the subway extension by 2021 is estimated to be 8,900 additional riders per hour (Metrolinx, 2009). This increase in capacity requires additional headway (from 141 seconds to 90 seconds) as well as the provision of added rolling stock. In addition, current subway trains are nearing full-capacity south of Bloor-Yonge Station (the subway systems' major nexus) with consistently longer dwell times. Cognizant of this, the City of Toronto has begun to explore options at solving such problems; this includes a six-platform concept upgrade from its current four platform model and the implementation of an automated signaling system (Metrolinx, 2009). Thus, a myriad of issues must be remediated before the extension can even be built. The catalyst from which any of these projects can materialize however, rests in the provision of funding.

Although outlined by Metrolinx (2008) as one of the most imperative initiatives for transit within the GGH, the Yonge subway extension is currently unfunded. The total capital cost of the six-station subway extension is estimated at $\$ 2.4$ billion with an annual operating cost of $\$ 11.4$ million (Metrolinx, 2009). Given these cost estimates, it is clear that funding from senior levels of government (i.e. provincial and federal) is required. At the time of writing this paper, however, the project is virtually in limbo. With a recent provincial shortfall and a looming provincial election in the fall of 2011, it does not seem likely that the Province will commit funding any time soon to transit infrastructure.

Given this scenario, there are a number of tools available to provide funding, but it requires the political will of all leaders within the GGH to commit to new funding tools and taxes that will provide adequate transit infrastructure. Indeed, given the neoliberal character of municipalities within the GGH vying for capital accumulation via large scale (new-build) developments, the time is now to think regionally at how an asset like transit can be implemented 
to further strengthen the GGH on the global scale. In doing so, derclopments like langstaft would not be in limbo if appropriate funding is secured early.

It is outside the scope of this paper to outline such tinancial tools and incentives, but some may include a regional sales tax, gas tax, road tools, or less regressive forms of tinancing that utilize land value capture tools such as tax-increment financing and tax increment-liascd grants (although such schemes do perpetuate neoliberal governance; sce Dyc \& Mcrriman, 2000; Weber, 2002). The latter may be an appropriate option for the Langstaff Gateway, given that the land value uplift is estimated to be from $\$ 482$ million to $\$ 1.2$ billion if the subway extension is indeed built (Metrolinx, 2009). If the growing trend in suburban development within the GGill is via the Langstaff Gateway model - as provincial and municipal competitive governance systems advocate - concerns over infrastructure funding will continually plague the region. Therelors, moving forward, it is in the best interest of all partics to collaboratively work logether at sceuring appropriate funding measures to build transit infrastructure. 


\section{Chapter 7: Conclusion - Lessons Learned From the Langstaff Gateway for Future}

Development in the GGH

The Langstaff Gateway represents the newest paradigm on a long list of development precedents championed by the Town of Markham. Although the site runs the risk of following its predecessors by manifesting into sprawl due to market forces, the land use and built form is reflective of what contemporary neighbourhoods within the GGH may represent moving forward. In addition, the implementation of regulatory planning frameworks via senior levels of government through the Growth Plan reflects a new hybridity of neoliberal governance in the GGH. The simultaneous facilitation and control of capital accumulation through urban growth centre policy may perpetuate developments analogous to the Langstaff Gateway, producing a new physical and social landscape currently unparalleled within the region. Given this notion, it is important to conclude this paper with a reflection upon how the Langstaff Gateway will significantly change the landscape of the GGH.

As the GGH has witnessed a plethora of new urbanist communities that are seemingly progressive, they have manifested into the status quo that is, ironically, suburban sprawl. The Town of Markham is at the forefront of this phenomenon, as the establishment of Cornell in the 1990s has perpetuated a new urbanist mantra for all new large-scale developments. Thus, the Town has established itself as a playground for new urbanist precedents, yet the outcome has been less than spectacular. Concession lots of land reflect cherry-picked design principles of new urbanism that suit the market, manifesting into automobile-dependent communities that exacerbate the growing traffic congestion problem in the GGH. Therefore, market actors, government bureaucrats and planning officials must not only lend credence to the core principles of new urbanism but ensure they are implemented on the ground.

Correspondingly, if the proposed densities and built form of the Langstaff Gateway do 
indeed become contemporary development benchmarks for similar municipalities, heavy reliance on the facilitation of transit infrastructure in the GGH will continually grow. Although an argument can be made that the Langstaff Gateway's physical boundaries and adjacent land uses further perpetuate the need for transit, similar developments analogous to Langstaff's density and population projections will also require some form of higher order transit. Given this notion, it is imperative for municipalities in the GGH to work collaboratively at implementing and funding the transit vision outlined by Metrolinx, without ultimately relying on financial contributions from senior levels of government.

The socioeconomic polarity that exists in regard to household income is continually perpetuated by higher housing demand in key locations throughout the GGH (i.e. the Toronto downtown core and outer suburbs), thus driving the price of housing beyond any form of affordability. Although new-build gentrification is a relatively new and highly contestable term that has yet to be fully studied under a North American, suburban context, its applicability to the GGH is certainly relative. The UK case studies have provided indicators of how large-scale development projects can perpetuate similar ramifications of traditional gentrification (albeit at a much large scale); the Langstaff Gateway is no different. Therefore, given that the Langstaff Gateway indeed represents a demonstration project for the GGH, policy must circumvent newbuild gentrification through appropriate affordable housing provisions by controlling market demand to allow inclusivity to lower income households, as well as youth and seniors. In doing so, the site will set a standard for other developments that follow in its footsteps.

Finally, the recommendations stated above are not solely relegated to the Langstaff Gateway. Municipalities across the GGH should employ the use of more progressive provisions such as pre-zoning and inclusionary housing strategies to remain transparent. In addition, it is 
imperative for municipalities to work collaboratively with each other to further streamline largescale infrastructure projects such as transit. The hybrid neoliberal governance structure that is present within the GGH currently lends credence to this collaborative notion, yet it also perpetuates municipal competitiveness through earmarked sites attributable to intense capital accumulation. Thus, it is imperative that planners and the planning profession continue to champion regulatory frameworks which produce social equity while facilitating economic competitiveness. Indeed, planning is politics; yet, if the two forces work together collaboratively, progressive and pragmatic changes on the ground can occur within the current political-economic framework that is embedded in local municipalities throughout North America and beyond. 
APPENDIX A: General Documents

Figure\#1: Wismer Commons, Land Use Map

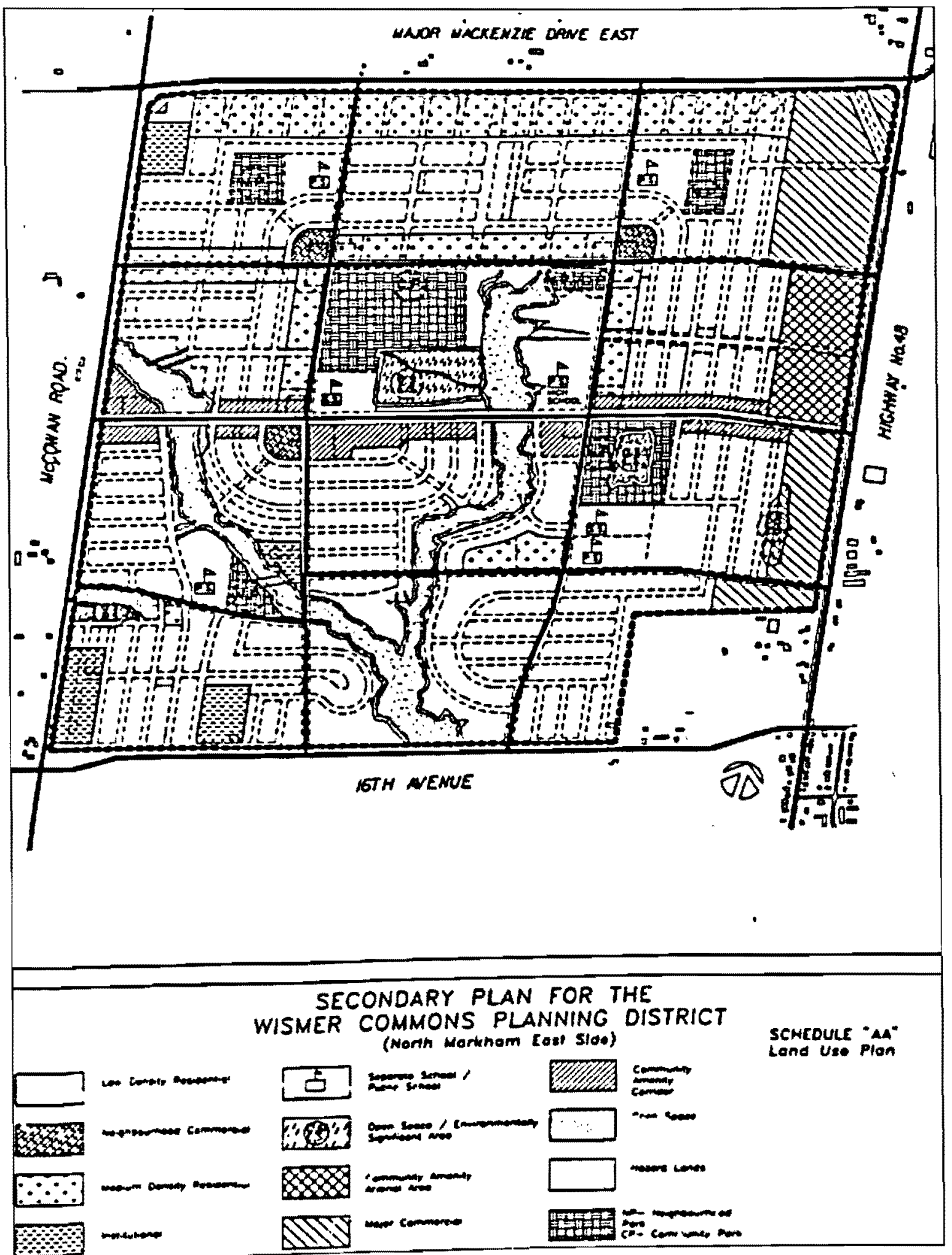

Source of image: Town of Markham, 1996 


\section{APPENDIX B: Provincial and Regional Documents}

\section{Figure \#1: Places to Grow Concept}

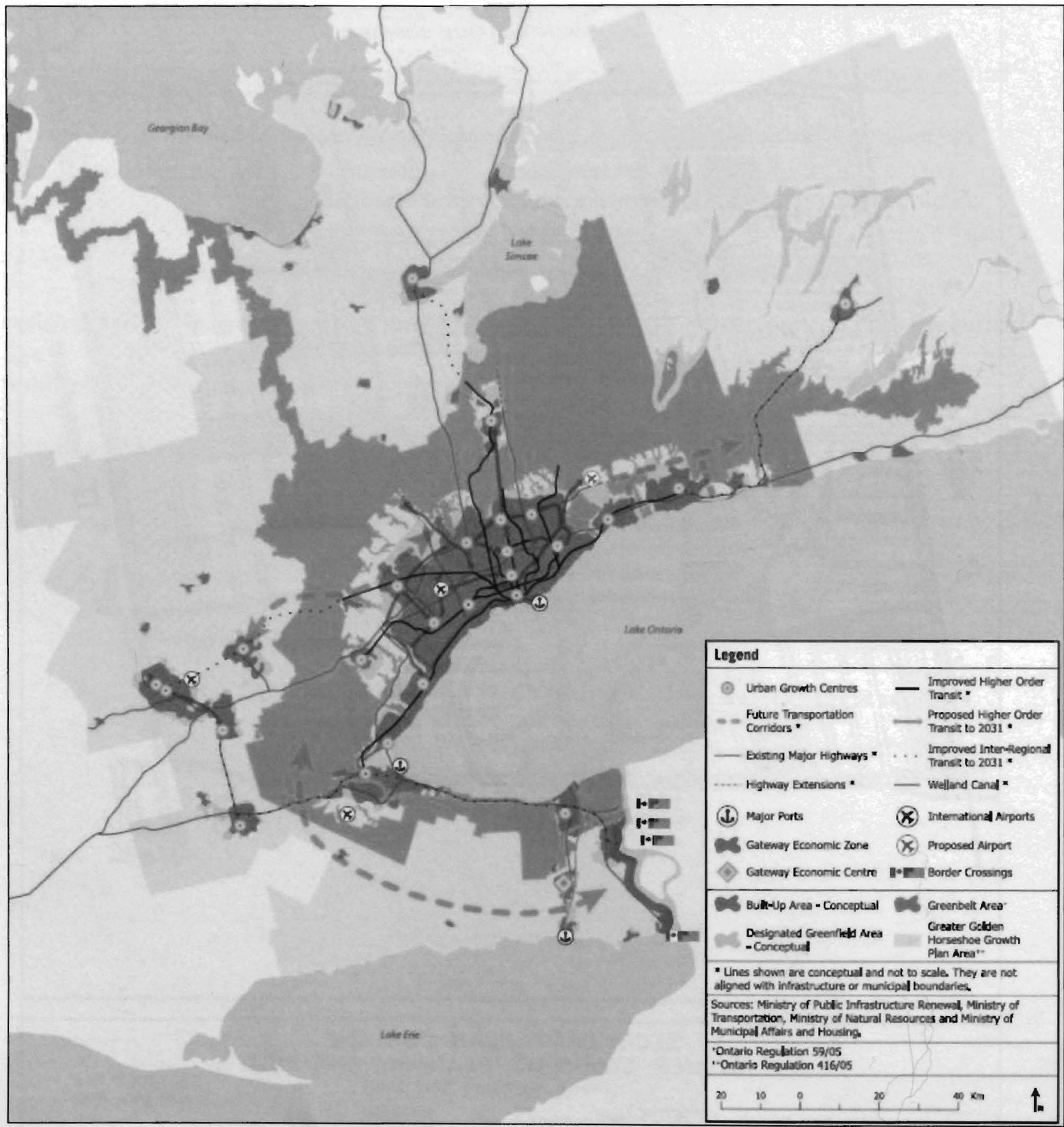

Source of image: Growth Plan, 2006 


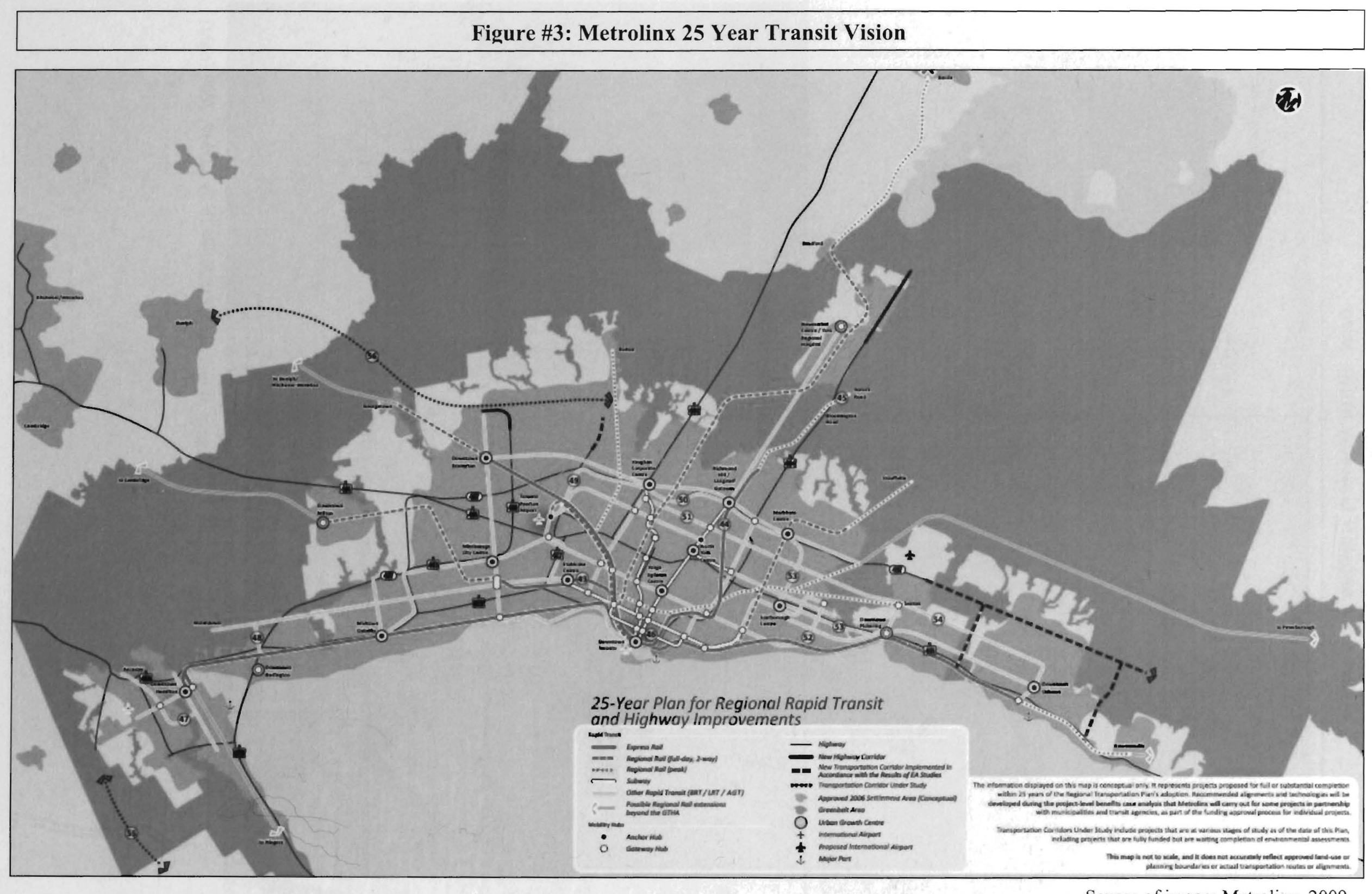

Source of image: Metrolinx, 2009 


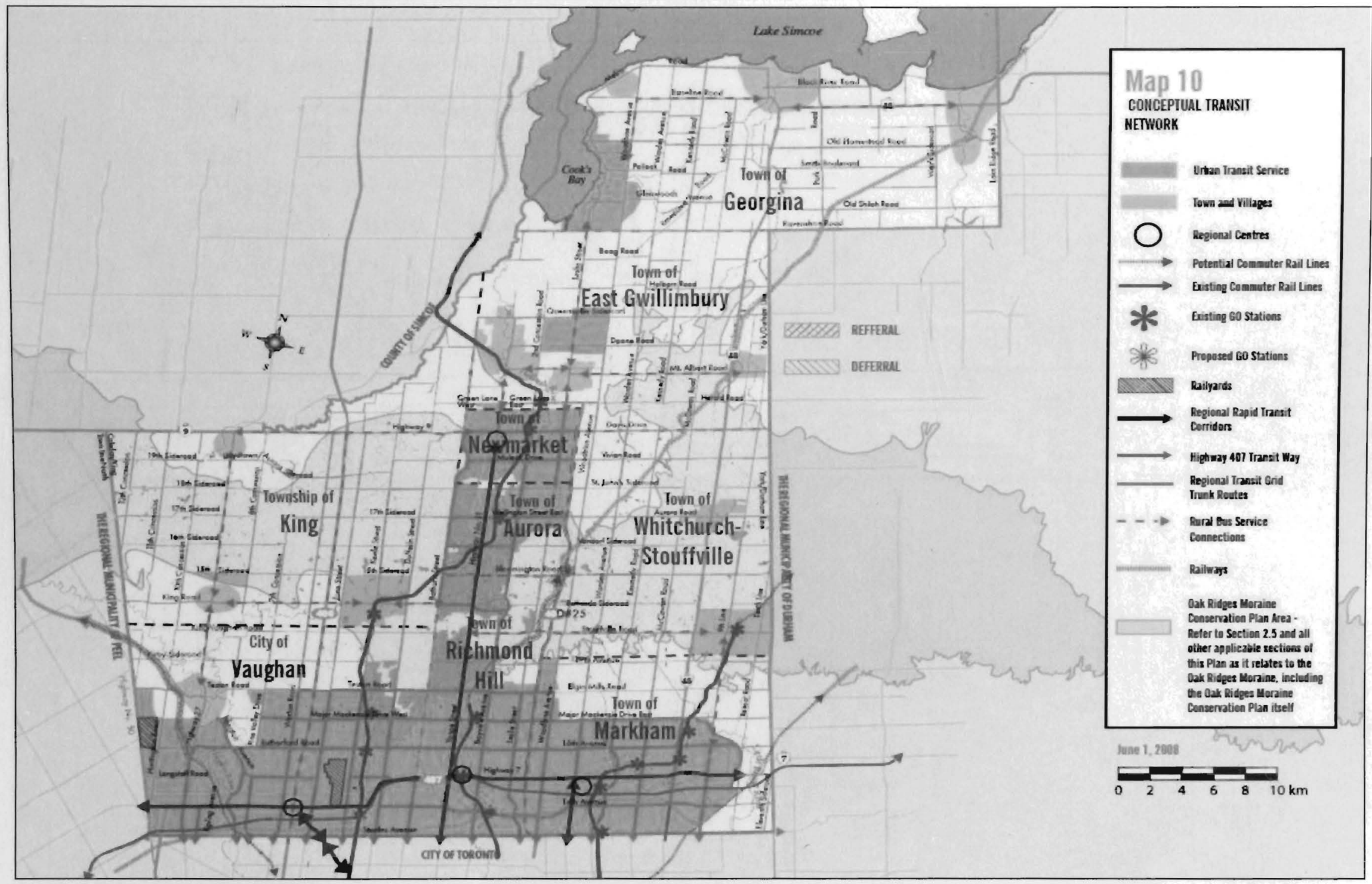




\section{APPENDIX C: List of Langstaff Gateway Documents}

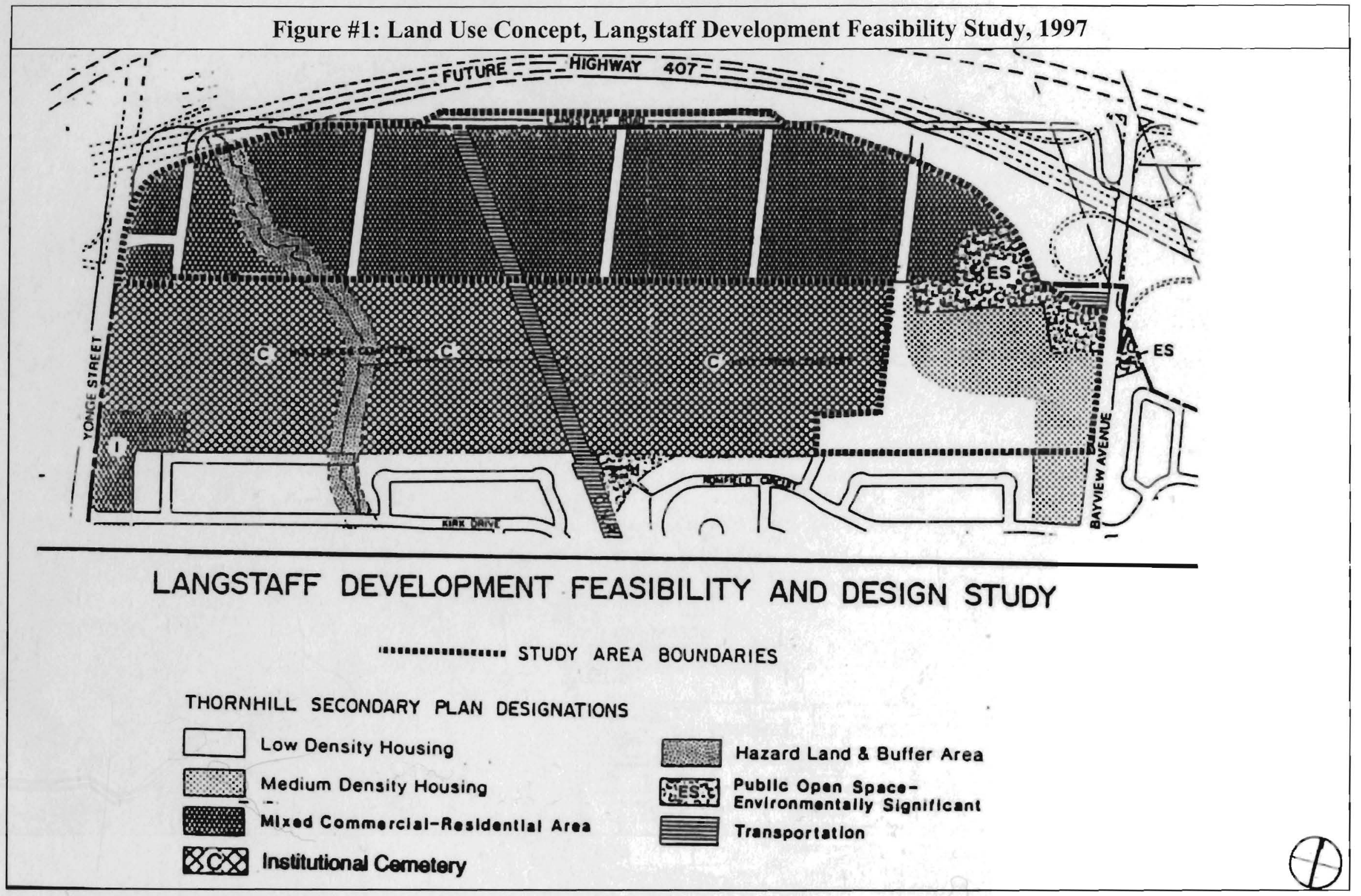




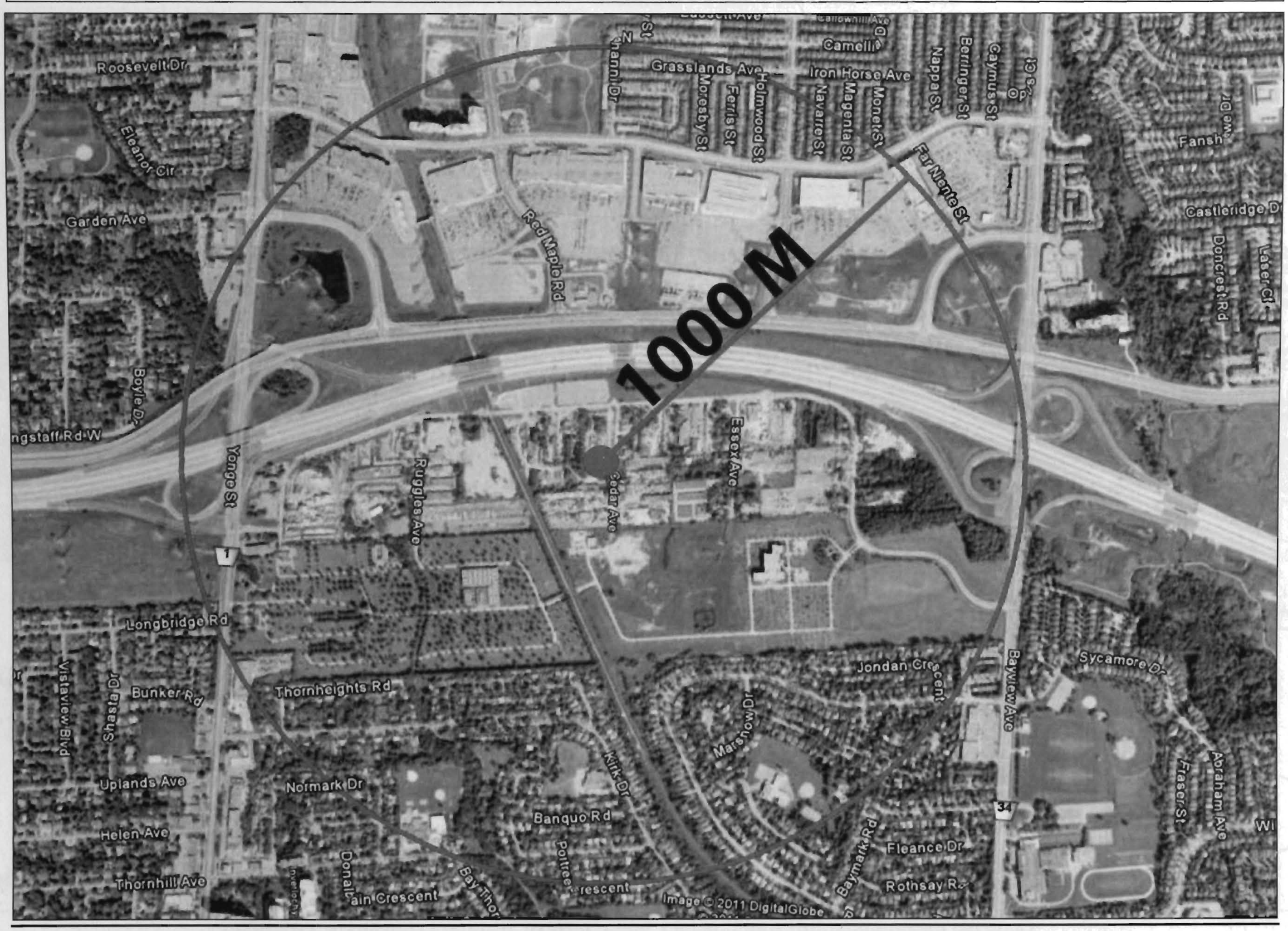


Figure \#3: Langstaff Gateway Master Plan, Phasing and Implementation Strategy

\section{PHASE ONE}

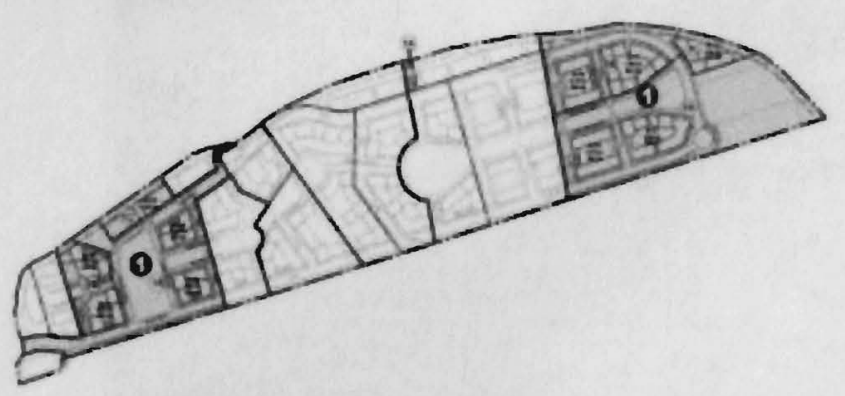

PHASE TWO

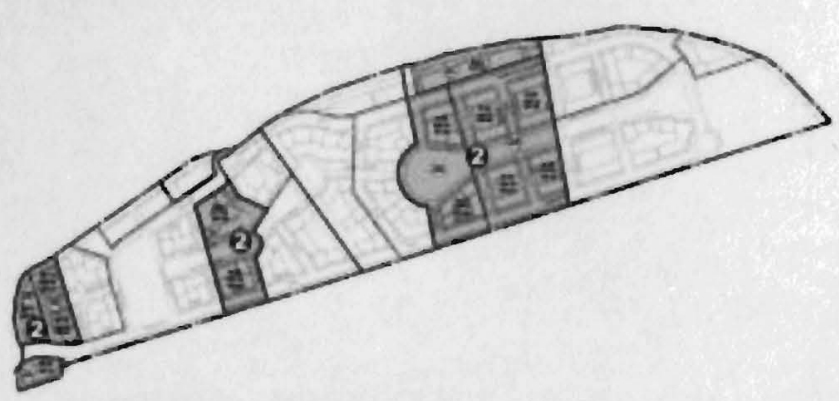

PHASE THREE

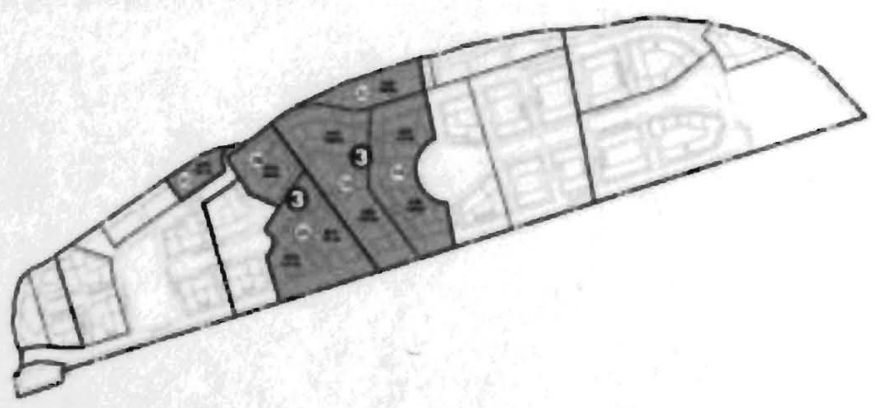

\begin{tabular}{|c|c|c|c|c|c|c|c|c|c|c|c|c|c|c|c|}
\hline & \multirow{2}{*}{\multicolumn{10}{|c|}{ Inemi Chiteria }} & \multirow{2}{*}{\multicolumn{3}{|c|}{ 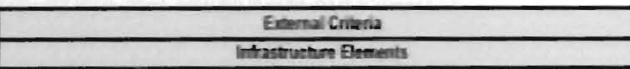 }} \\
\hline & & & & & & & & & \multirow[b]{2}{*}{ Petiomance } & \multirow{2}{*}{\multicolumn{3}{|c|}{ 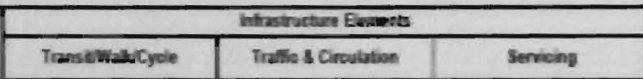 }} & & & \\
\hline & & & Amisentsy & Residential Semices & 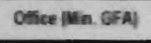 & Metal & ane & Open Sproces & & & & & \multicolumn{3}{|c|}{ 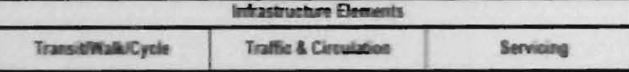 } \\
\hline \multirow{2}{*}{ 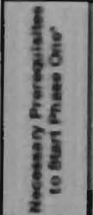 } & & & None & $=$ & mone & $\infty$ & sune & woen & $=$ & 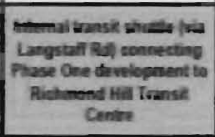 & 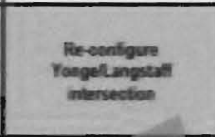 & Hose & moot & & Nome \\
\hline & & & & & & & & & & & 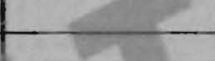 & & & & \\
\hline \multirow{10}{*}{ 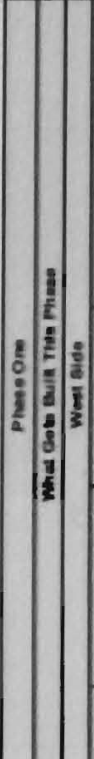 } & \multirow{3}{*}{ 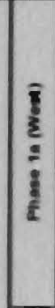 } & \multirow{3}{*}{$\begin{array}{l}\frac{1}{5} \\
\frac{3}{1} \\
\frac{1}{3} \\
\frac{1}{8} \\
\frac{1}{8}\end{array}$} & sat wis & 2000 с & & & ms se & $\begin{array}{l}\text { menclient } \\
\text { Pati }\end{array}$ & 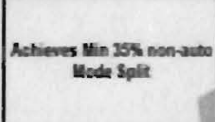 & & 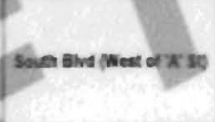 & 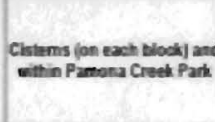 & 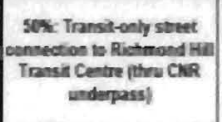 & None & 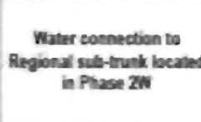 \\
\hline & & & & & & & & 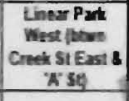 & & & 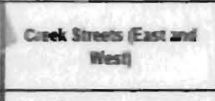 & 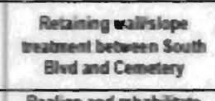 & & & 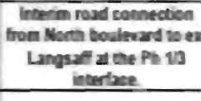 \\
\hline & & & & & & & & & & & 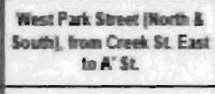 & 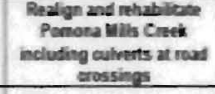 & & & 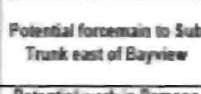 \\
\hline & \multirow{3}{*}{ 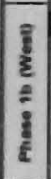 } & \multirow{3}{*}{ 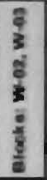 } & Lall unts & $20 \times x=$ & & 2.195 squ & $300 \mathrm{Ma}=$ & 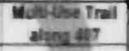 & 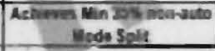 & Hone & Subsery Lane & 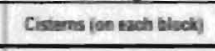 & some & None & 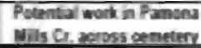 \\
\hline & & & & & & & & & 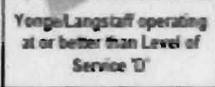 & & 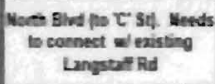 & 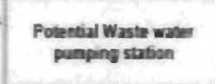 & & & \\
\hline & & & & & & & & & 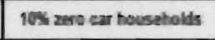 & & West Hain Sreet & 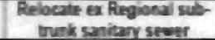 & & & \\
\hline & \multirow{3}{*}{ 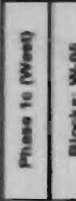 } & 8 & & & $30 \mathrm{com} \mathrm{sq}=$ & & & 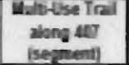 & 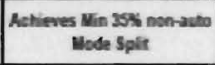 & Nome & Th Sunet & 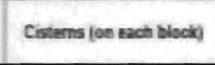 & None & Noon & Mose \\
\hline & & $\frac{8}{4}$ & & & & & & & 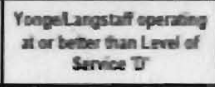 & & & 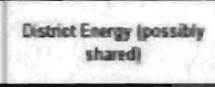 & & & \\
\hline & & & & & & & & & 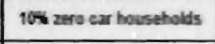 & & & 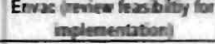 & & & \\
\hline & $\frac{3}{2}$ & & 2007 unts & $1,70 \mathrm{sq}=$ & $30.00 \mathrm{san}$ & ians squ & $1501 \mathrm{sem}$ & & & & & & & & \\
\hline
\end{tabular}


Figure \#4: Langstaff Gateway Secondary Plan, Proposed Land Use

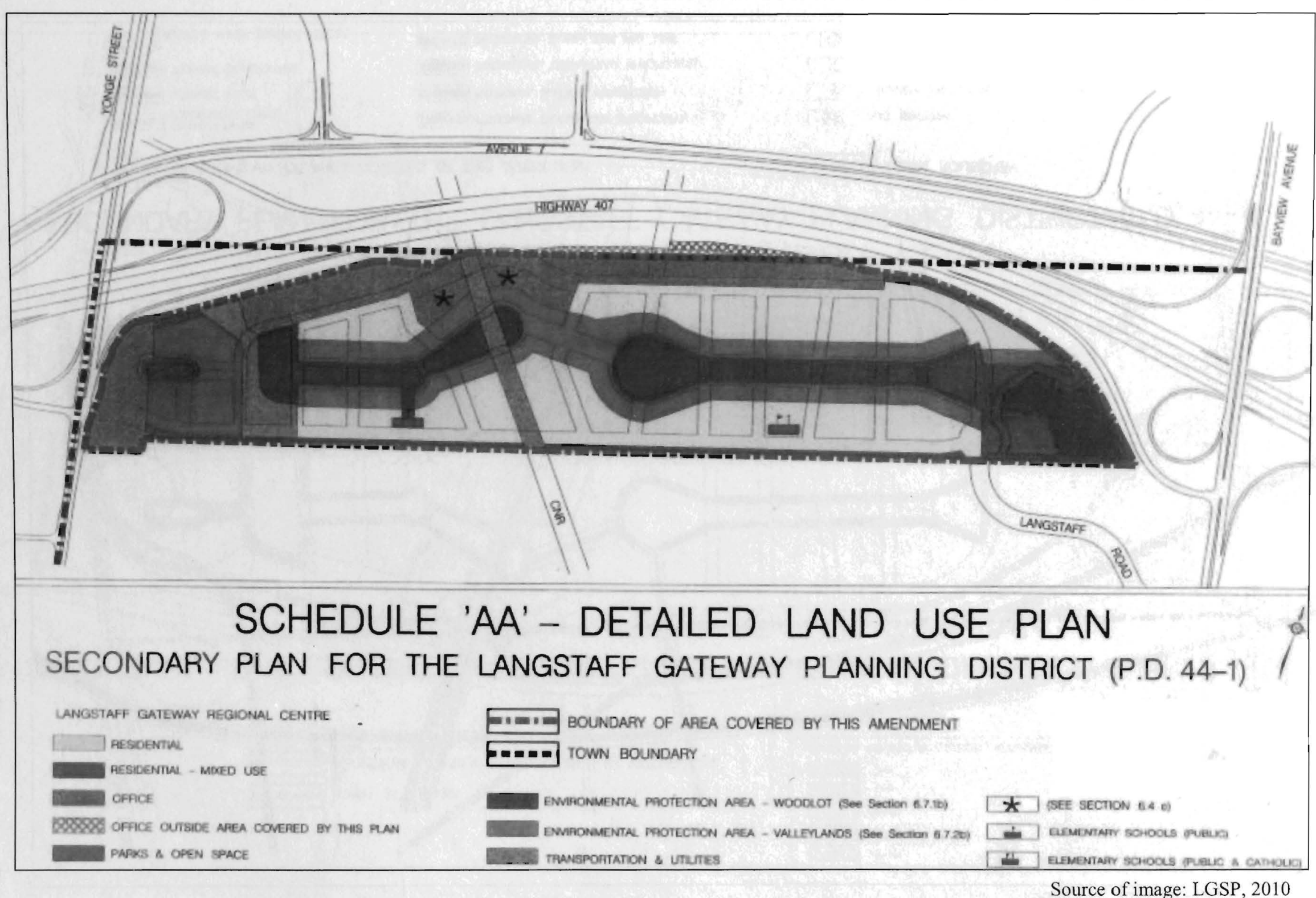




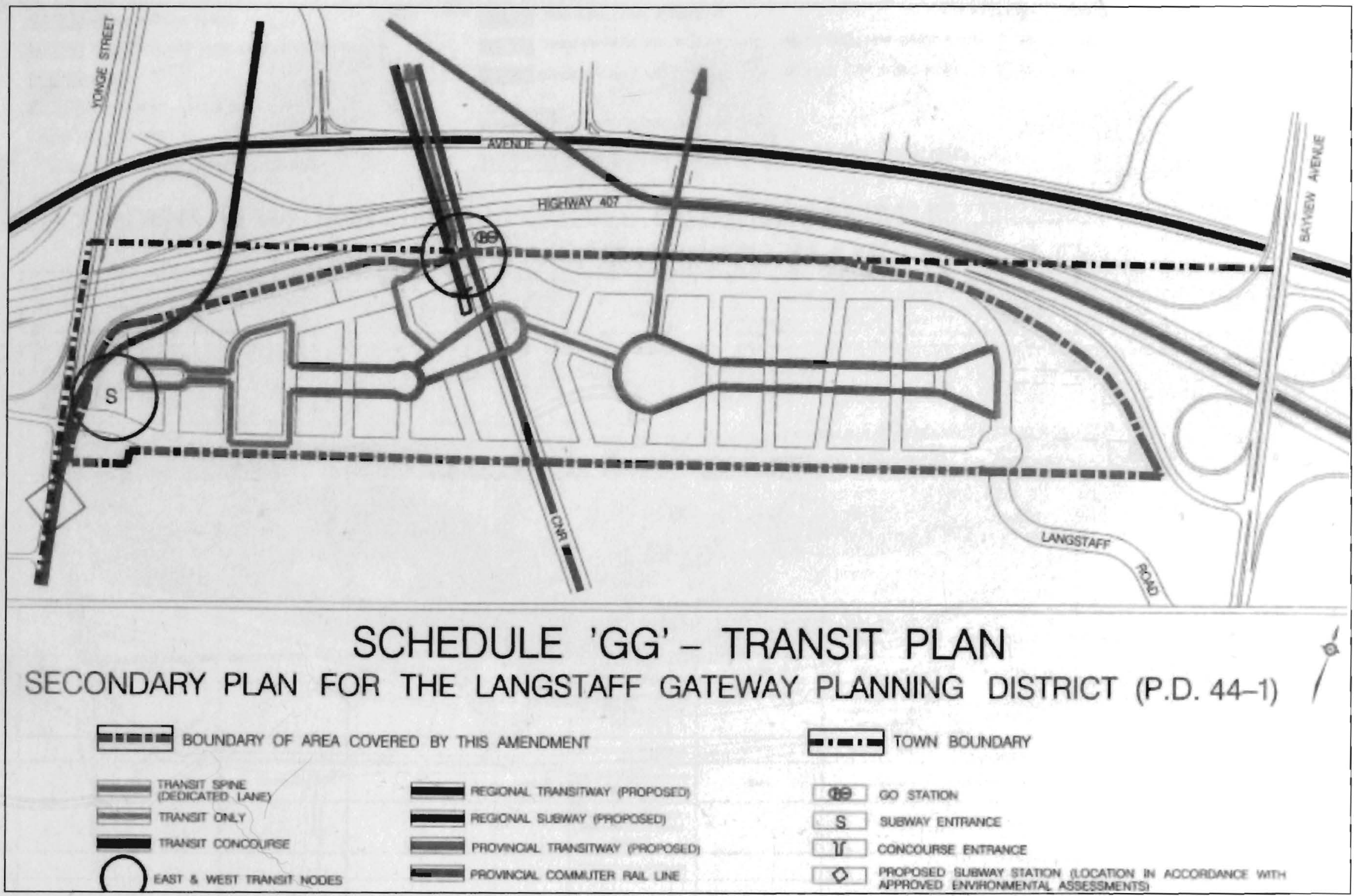




\section{Figure \#6: Langstaff Gateway Secondary Plan, Height Control Plan}

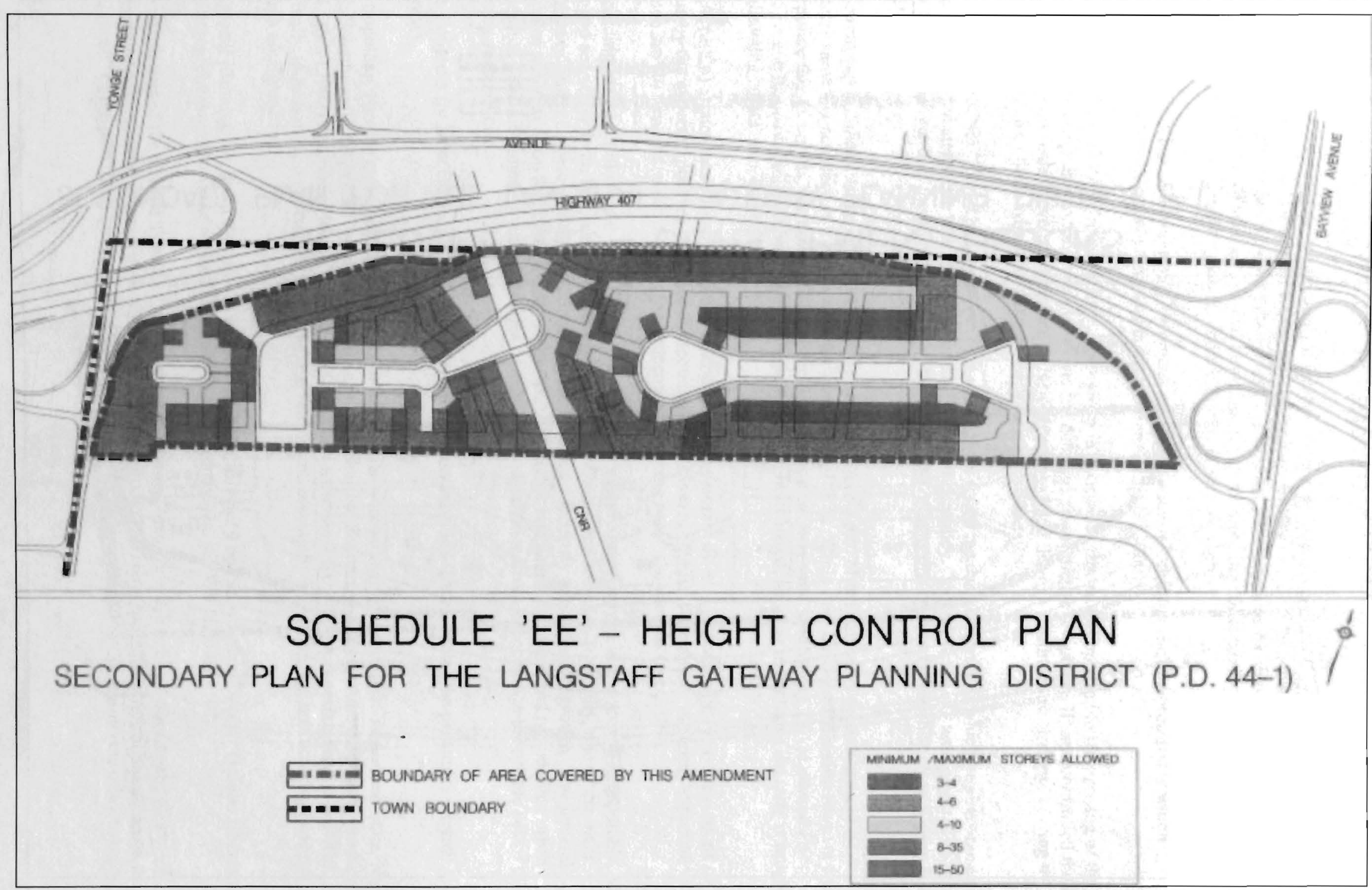


Figure \#7: Langstaff Gateway Secondary Plan, Development Blocks and FSI

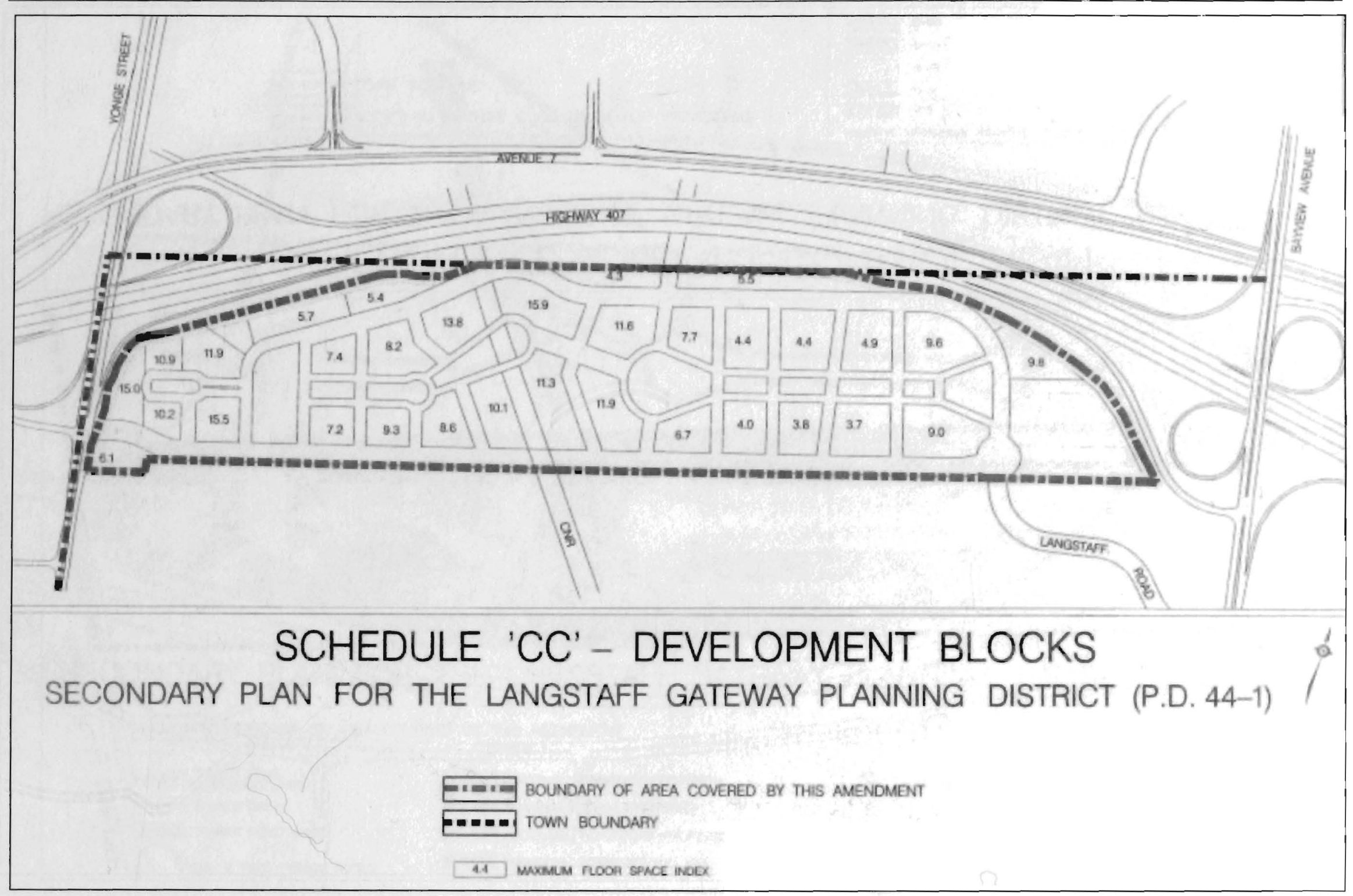




\section{$\underline{\text { Endnotes }}$}

'The Washington Consensus most commonly refers to a reform package of neoliberal principles meant to adjust structural inefficacies within the global south. Coined by John Williamson in 1989 and backed by institutions such as the World Bank and International Monetary Fund, the Washington Consensus incorporated key aspects for macroeconomic stabilization such as minimal government intervention, the elimination of government subsidies, fiscal austerity, privatization, deregulation, and well-defined property rights.

${ }^{2}$ Governmentality refers to the how of government, and its mechanisms, techniques, and procedures which bureaucrats deploy to implement policy and enact programs (Lamer, 2000)

${ }^{3}$ According to Slater (2009), "revanchists" were a group of bourgeois nationalists opposed to the uprising of the Paris Commune, where the working class took over the defeated government of Napolean III and controlled the city for months. The revanchists were determined to restore order to Paris through a militaristic strategy, vowing to enact revenge on all of those who "stole" their vision of French Society.

${ }^{4}$ As stated above, New York City under Mayor Rudy Giuliani forms the basis of Smith's, which had become an arena for concerted attacks on affirmative action and immigration policy. Indeed, the newly amalgamated City of Toronto under Mayor Mel Lastman at the end of the 1990s also reflects that of urban revanchism (see Kipfer \& Keil, 2000).

5 The rent gap is defined as the space between the actual value of a plot of land given its present use and its potential value characterized as a higher or better use (Smith, 1987). While new-build gentrification may very well incorporate this theory (as, for example, brownfield redevelopment may raise land value), Davidson and Lees (2005) argue that new-build gentrification is singular and corporate based, and that many times the state is involved at redirecting capital to achieve its own goals.

${ }^{6}$ Niedt (2006) argues that pro-gentrification discourse enables current owners to avoid simplistic accusations of racism by the expected positive attributes of incoming upper-class residents. He employs the term "suburban revanchism" to describe white middle-class homeowners "taking back" the suburbs (see p.104).

${ }^{7}$ According to Grant (2005) and White (2007), the ideology behind Smart Growth is that growth is inevitable, and if managed correctly, it can become healthy economically, physically, and socially. Ironically, one of the main premises of Smart Growth was that planning controls should not seriously impede urban growth. The general principles of Smart Growth include transit-supportiveness, higher residential densities, and maintaining urban . boundaries. The movement involved the idea of using government incentives to encourage the private sector at adopting such policies.

${ }^{8}$ The Congress for New Urbanism is the leading non-profit organization that promotes the principles of new urbanism.

${ }^{9}$ Metropolitan Toronto consisted of the city of Toronto and its inner municipalities of East York, Etobicoke, North York, Scarborough, and York. Toronto's amalgamation of the above municipalities became official on January $1^{\text {st }}$, 1998. Keil (2002) describes Metro Toronto as the political-institutional fix within Keynesian-Fordist growth, eventually transitioning into "roll-out" neoliberalist reform and essentially beginning this restructuring process through amalgamation.

${ }^{10}$ Regional planning has had a tumultuous history within the Greater Toronto Area and Greater Golden Horseshoe. For a comprehensive history of regional planning in the Toronto area, see White, 2007.

"Formerly named the Greater Toronto Transportation Authority, Metrolinx is a public authority aimed at integrating multi-modal regional transit within the Greater Toronto and Hamilton Area. Metrolinx is seen as the "final piece" of the provincial government's three part approach for growth within the region (the other two pieces 
being the Greenbelt and Growth Plan). The provincial government passed legislation to constitute Metrolinx (the Metrolinx Act, 2006), and "to improve the coordination and integration of all modes of transportation in the region" (Metrolinx, 2009).

${ }^{12}$ The built up area and built boundary refer to the limits of a developed (or serviced) urban area, and is delineated by the province in conjunction with municipalities (Growth Plan, 2006). 


\section{$\underline{\text { References }}$}

Atkinson, R. (2003) "Domestication by cappuccino or a revenge on urban space?

Control and empowerment in the management of public spaces." Urban Studies 40 (9) pp1829-1843.

Addie, J-P, Fiedler, R. (2008). Canadian cities on the edge: Reassessing the Canadian suburb. The City Institute at York University. Occasional Paper Series. 1

Boddy, M (2007). Designer neighbourhoods: new-build residential development in nonmetropolitan UK cities - the case of Bristol. Environment and Planning A. 39: 86105

Boudreau, J, Keil, R, Young, D. (2009). Changing Toronto: Governing urban neoliberalism. University of Toronto Press: Toronto.

Bourne, L. (1996). Reinventing the Suburbs: Old Myths and New Realities. Progress in Planning, 46(3): 163-184.

Bourdieu, P. (1998). Acts of resistance. Cambridge, UK: Polity Press

Brenner, N. (1998). Global cities, 'glocal' scales: Global city formation and state territorial restructuring in contemporary Europe. in Brenner, N, and Keil, R (eds) the Global Cities Reader. Routledge.

Brenner, N \& Theodore N. (2002). Cities and the geography of "actually existing neoliberalism". Antipode. 34 (3): 349-379

Bunce, S. (2007). Gentrifying sustainability: Policy, planning, and the development of sustainability on Toronto's central waterfront. Toronto: York University.

Butler, T. (2002). Thinking global but acting local: the middle classes in the city. Sociological Research. Volume 7.

Butler, T. (2007). For gentrification? Environment and Planning A. 39: 162-81

Caulfield, J. (1994). Excerpts from City form and everyday life: Toronto's gentrification and critical social practice. Toronto: University of Toronto Press.

Caulfield, J. (2005). Toronto: The form of the city. In Harry, H (ed) Urban Canada: Sociological Perspectives. Oxford University Press. 312-342.

Chatterjee, L, Lakshmanan, T.R. (2009). New governance institutions in the entrepreneurial urban region. The European Journal of Social Science Research. 22 (3): 371-391

Chritstoforidis, A. (1994). New alternatives to the suburb: Neo-traditional developments. Journal of Planning Literature. 8 (4): 429-440. 
Cook, N, Ruming, K. (2008). On the fringe of neoliberalism: Residential development in outer suburban Sydney. Australian Geographer. 39 (20): 211-228

Craig, D, Porter, D. (2006). Development beyond neoliberalism? governance, poverty reduction, and political economy. Routledge: London.

Davidson, M, Lees, L. (2005). New-build 'gentrification' and London's riverside renaissance. Environment and Planning A. 37: 1165-1190.

Davidson, M, Lees, L. (2010). New-build gentrification: Its histories, trajectories, and critical geographies. Population, Space, and Place. 16: 395-411

Davidson, M. (2007). Gentrification as global habitat: a process of class formation or corporate creation? Transactions of the Institute of British Geographers. 32(4): 490-506.

Digital Globe. (2011). Langstaff gateway (coordinate: $43^{\circ} 50^{\circ} 06.31$ "N $79^{\circ} 25^{\circ} 7.44 \mathrm{~W}$ elevation: 0) Accessed via Google Earth (Version 6.0.1.2032) (Software). Mountain View, CA: Google Inc.

Duany, A, Plater-Zyberk, E, Speck, J (2000). Suburban nation: The rise of sprawl and the decline of the American dream. New York: North Point Press

Dye, R, Merriman, D. (2000). The effects of tax increment financing on economic development. Journal of Urban Economics. 47: 306-328

Fleischer, D. (2009). Metrolinx, region still working on subway extension goal. York Region online. Retrieved March $20^{\text {th }}, 2011$ from: http://www.yorkregion.com/YorkRegion/Article/550073

Fleischer, D. (2010). Markham aims to boost population, job density. York Region online. Retrieved March $16^{\text {th }}, 2011$ from: http://www.yorkregion.com/news/local/article/626812--markham-aims-to-boostpopulation-job-density

Forsyth, A, Crewe, K. (2009). New visions for suburbia: Reassessing aesthetics and placemaking in modernism, imageability, and new urbanism. Journal of Urban Design. 14 (4): 415-438.

Friedman, M. (1962). Capitalism and freedom. University of Chicago Press: Chicago.

Friedmann, J. (1986). The world city hypothesis. in Brenner, N, and Keil, R (eds) the Global Cities Reader. Routledge. 
Gause, J. (2002). Great planned communities. Washington: Urban Land Institute.

Glass, R. (1964). Introduction to London: Aspects of change centre for urban studies. London (reprinted in Glass R, 1989 Cliches of Urban Doom). Blackwell, Oxford.

Gordon, D, Tamminga, K. (2002). Large-scale traditional neighbourhood development and preemptive ecosystem planning: The Markham experience, 1989-2001. Journal of Urban Design. 7 (3): 321-340.

Grant, J. (2002). Mixed use in theory and practice: Canada's experience with implementing a planning principle. Journal of the American Planning Association. Winter 68 (1): 71-84

Grant, J. (2005). Planning the good community: New urbanism in theory and practice. Routledge: New York.

Grant, J. (2009). Theory and practice in planning the suburbs: Challenges to implementing new urbanism, smart growth, and sustainability principles. Planning Theory and Practice. 10 (1): 11-33

Greenbelt Plan - Ministry of Municipal Affairs and Housing. (2005). Greenbelt plan. available from: http://www.mah.gov.on.ca/Asset1277.aspx

Growth Plan - Ministry of Public Infrastructure Renewal (2006). Growth plan for the greater golden horseshoe. p. 1-48. Queens Printer for Ontario.

Hackworth, J, Smith, N. (2001). The changing state of gentrification'. The Dictionary of Human Geography. 22: 464-477

Hall, T, Hubbard, P. (1996). The entrepreneurial city: new urban politics, new urban geographies? Progress in Human Geography. 20: 153-174

Hamnet, C. (2000). Gentrification, postindustrialism, and industrial and occupational restructuring in global cities. In Bridge, $\mathrm{G}$ and Watson, $\mathrm{S}$ (eds) A Companion to The City. Blackwell, 331-341

Hanlan, J. (2010). Success by design: HOPE IV, new urbanism, and the neoliberal transformation of public housing in the United States. Environment and Planning A. 42: 80-98

Harvey, D. (1982). The limits to capital. Oxford: Blackwell

Harvey, D. (1989a). From managerialism to entrepreneurialism: The transformation in urban governance in late capitalism. Geografiska Annaler. Series B, Human Geography. 71 (1) 3-17. 
Harvey, D. (1989b). The Condition of Postmodernity. Oxford: Basil Blackwood.

Harvey, D. (1997). The new urbanism and the communitarian trap. Harvard Design Magazine. Winter/Spring

Harvey, D. (2005). A brief history of neoliberalism. Oxford University Press: Oxford

Hayek, F. (1944). The road to serfdom. University of Chicago Press: Chicago.

Hirt, S. (2009). Premodern, modern, postmodern? Placing new urbanism into a historical perspective. Journal of Planning History. 8 (3): 248-273

HUD. United States Department of Housing and Urban Development. (2011). Housing choice vouchers fact sheet. Retrieved April 3, 2011 from:

http://portal.hud.gov/hudportal/HUD?src=/program_offices/public_indian_housing/progr ams/hcv/about/fact_sheet

Hulchanski, D. (1990). Planning new urban neighbourhoods: Lessons learned from Torornto's St. Lawrence Neighbourhood. UBC Planning Papers. Canadian Planning Issues. 28.

Jacobs, J. (1961). The death and life of great American cities. Random House: New York

Keil, R. (2002). "Common-sense" neoliberalism: Progressive conservative urbanism in Toronto, Canada. Antipode. 34 (3): 578-601

Kipfer, S, Keil, R. (2002). Toronto inc? Planning the competitive city in the new Toronto. Antipode. 34 (2): 227-264

Krier, L. (1978). The reconstruction of the city. Rational Architecture. La reconstruction de la ville Europeanne, Bruxells: Archives d'Architecture Moderne, pp.38-42, 163-80.

Lambert C, Boddy, M. (2002). Transforming the city: post-recession gentrification and reurbanisation. Gentrification in the New Century. September. University of Glasgow.

Lamer, W. (2000). Neo-liberalism: Policy, ideology, governmentality. Studies in Political Economy. 63: 5-25

Larner, W. (2005). Neoliberalism in (regional) theory and practice: The stronger communities action fund in New Zealand. Geographical Research. 43 (1): 9-18.

Lee, C-M, Ahn, K-H. (2003). Is Kentlands better than Radburn? The American garden city and new urbanist paradigms. Journal of American Planning Association. 69 (1): 50-71. 
Lees, L. (2003). Super-gentrification: the case of Brooklyn Heights, New York City. Urban Studies. 40: 2487-2509

LDFS. (1995). Langstaff development feasibility and urban design study. The Butler Group.

LGMP. (2009). Langstaff gateway land use and built form master plan. Calthorpe and Associates/Ferris + Associates Inc. Available at: http://www.markham.ca/Markham/Departments/Planning/Studies/Studies_Langstaff + Ma ster+Plan+Project.htm

LGSP. (2010). Official plan amendment no.183 and secondary plan for the Langstaff Gateway planning district. Town of Markham Development Services Commission.

Ley, D. (1987) Reply: the rent-gap revisited. Annals of the Association of the American Geographers. 1987.

Ley, D. (1996). The new middle class and the remaking of the central city. Oxford University Press. Oxford.

Lister, N-M. (2007). Sustainable large parks: Ecological design or designer ecology? In: J. Czerniak \& G. Hargreaves (eds.), Large Parks. Princeton Architectural Press. pp. 31-51

Lynch, K. (1960). The image of the city. MIT Press. Cambridge.

MacLeod, G. (2002) "From urban entrepreneurialism to a 'revanchist city'? On the spatial injustices of Glasgow's renaissance." Antipode 34 (3): 602-624.

McGuirk, P.M. (1997). Multiscaled interpretations of urban change: the federal, the state, and the local in the Western Area Strategy of Adelaide. Environment and Planning D: Society and Space. 15: 481-498.

McGuirk, P.M. (2005). Neoliberalist planning? Re-thinking and re-casting Sydney's metropolitan planning. Geographical Research. 43 (1): $59-70$

Metrolinx. (2008). The big move: Transforming transportation in the greater Toronto and Hamilton area. The Greater Toronto Transportation Authority.

Metrolinx. (2009). Yonge north subway extension benefits case. Metrolinx. Retrieved March $6^{\text {th }}$ from: http://www.metrolinx.com/mx/docs/Yonge-North_BCA_Report_FINAL.pdf

Mills, C. (1988). Life on the upslope: the postmodern landscape of gentrification' Environment and Planning D: Society and Space 6: 169-189. 
Mills C. 1993. Myths and meanings of gentrification. In Duncan J, Ley D (eds.) Place/Culture/Representation: London: Routledge: 149-170.

MMAH. (2007). Key benefits of the development permit system. Ministry of Municipal Affairs and Housing, Online. Retrieved March $20^{\text {th }}, 2011$ from:

http://www.mah.gov.on.ca/Page4820.aspx

Moore, S. (2010). 'More Toronto, naturally' but 'too strange for Orangeville': De-universalizing new urbanism in Greater Toronto. Cities. 27: 103-113

MPIR - Ministry of Public Infrastructure Renewal. (2006). Places to grow. Better choices. Brighter future. Growth plan for the Greater Golden Horseshoe. Queens Printer for Ontario. 1-48.

MPIR - Ministry of Public Infrastructure Renewal. (2008). Proposed size and location of urban growth centres in the Greater Golden Horseshoe. Ministry of Public Infrastructure Renewal. 1-65.

Murphy, P.A, Wu, C. (1999). Governing global Sydney: from managerialism to entrepreneurialism. Urban and Regional Governance in the Asia Pacific. September: 1732 .

Neuman, L. (2006). Social research methods: Qualitative and quantitative approaches. University of Wisconsin. Pearson. Boston.

Niedt, C. (2006). Gentrification and the grassroots: Popular support in the revanchist suburb. Journal of Urban Affairs. 28 (2): 99-120

Owen, K.A. (2002). The Sydney 2000 Olympics and urban entrepreneurialism: Local variations in urban governance. Australian Geographical Studies. 40 (3): 323-336.

Peck, J, Tickell, A. (2002). Neoliberalizing space. Antipode. 34 (3): 380-404

Phillips, M. (1993). Rural gentrification and the processes of class colonization. Journal of Rural Studies. 9:123-140

Phillips, M. (2002). The production, symbolization and socialization of gentrification: impressions from two Berkshire villages'. Transactions of the Institute of British Geographers. 27: 282-308

Rofe, M. (2003). I want to be global: Theorising the gentrifying class as an emergent lite global community. Urban Studies. 40:2511-2526 
Robson, G, Butler, T. (2001). Coming to terms with London: middle-class communities in a global city. International Journal of Urban and Regional Research. 25: 70-86

Ruckert, A. (2006). Towards an inclusive-neoliberal regime of development: From the Washington to the post-Washington consensus. Labour, Capital and Society 39 (1): $34-67$

Ruming, K.J. (2005) Partnership, master planning and state provision: A case study of "actually existing neoliberalism" on the central coast. Geographical Research. 43: 8292.

Sassen, S. (1996). Cities and communities in the global economy. in Brenner, N, and Keil, R (eds) the Global Cities Reader. Routledge.

Sassen, S. (2002). Locating cities on global circuits. in Brenner, N, and Keil, R (eds) the Global Cities Reader. Routledge.

Sieverts, T. (2003). Cities without cities: An interpretation of the zwischenstadt. London: Spoon Press.

Skaburskis, A. (2006). New urbanism and sprawl: a Toronto case study. Journal of Planning Education and Research. 25: 233-248.

Slater, T. (2009) Revanchist city. in R. Hutchison (ed.) The Encyclopaedia of Urban Studies (Thousand Oaks: Sage)

Smith, N. (1984). Uneven development: nature, capital and the production of space. Basil Blackwell.

Smith, N. (1987). Gentrification and the rent gap. Annals of the Association of American Geographers. 77(3):462-465.

Smith, N. (1996). The new urban frontier: Gentrification and the revanchist city. Routledge. London.

Smith, N. (2002). New globalism, new urbanism: gentrification as global urban strategy'. Antipode. 34, 427-450.

Soederberg, S. (2005). Recasting neoliberal dominance in the global south? A critique of the monterrey consensus. Alternatives. 30:325-364.

Song, Y, Knapp, G-J. (2003). New urbanism and housing values: A disaggregate assessment. Journal of Urban Economics. 54: 218-238. 
Sorkin, M. (2007). The end(s) of urban design. Harvard Design Magazine, (Spring/Summer): 418.

Swyngedouw, E, Moulaert, F, Rodriguez, A (2002). Neoliberal urbanization in Europe: Largescale urban development projects and the new urban policy. Antipode. 34 (3): 519-540

Toronto Board of Trade. (2010). Lifting all boats: promoting social cohesion and economic inclusion in the Toronto region. Toronto Board of Trade.

Town of Markham. (1996). Official plan amendment and secondary plan - wismer commons. Town of Markham Development Services Commission.

Town of Markham. (2008). Official plan of the town of Markham planning area amendment no.171 (Langstaff urban growth centre area). Town of Markham Development Services Commission.

Town of Markham. (2010b). Economic profile, year end, 2010. Town of Markham Economic Development Department. Retrieved March $23^{\text {rd }}, 2011$ from: http://www.markham.ca/NR/rdonlyres/3A5704C2-14B8-4D87-BE6CD3F748A56D7B/0/economicprofile yearend10.pdf

Town of Markham. (2010b). Affordable and special needs housing strategy - draft discussion paper. SHS Consulting.

Town of Markham. (2011). Statistics and demographics . retrieved March 5th, 2011 from: http:/www.markham.ca/Markham/Departments/EDO/Stats.htm

TTC. (2008). Toronto transit commission report: Yonge subway extension - final report on transit project assessment process and future actions. Toronto Transit Commission. Retrieved March 6th from:

http://www3.ttc.ca/About_the_TTC/Commission_reports_and_information/Commission meetings/2008/Dec_17_2008/Supplementary_Reports/Yonge\%20Subway\%20Extensi.pd f

Uitermark, J. and Duyvendak, J.W. (2008) "Civilising the city: populism and revanchist urbanism in Rotterdam." Urban Studies 45 (7) pp 1485-1503.

Viva. (2008). Yonge subway business base: The missing link. VivaNext. Retrieved march $23^{\text {rd }}$, 2011 from: http://www.vivanext.com/assets/files/pdfs/TheMissingLink_Press_Final.pdf

Waldheim, C. (2006). Landscape as urbanism. In Waldheim, C (ed.) The Landscape Urbanism Reader, pp. 37-53. 
Warde, A. (1991) Gentrification as consumption: issues of class and gender' Environment and Planning D: Society and Space 9: 223-232

Weber, R. (2002). Extracting value from the city: Neoliberalism and urban redevelopment. Antipode. 34 (3). 519-540

White, R. (2007). The growth plan for the greater golden horseshoe in historical perspective. p.152. Neptis Foundation.

York Region. (2008). The Regional Municipality of York official plan. Office Consolidation. The Regional Municipality of York.

Zukin S, 1991 Landscapes of power: from Detroit to DisneyWorld. University of California Press. Berkeley, CA. 